\title{
WestVirginiaUniversity
}

THE RESEARCH REPOSITORY @ WVU

Graduate Theses, Dissertations, and Problem Reports

1999

\section{Effects of fermenten during the dry and early lactation periods of dairy cows}

Wellington Sifuna Mang'oli

West Virginia University

Follow this and additional works at: https://researchrepository.wvu.edu/etd

\section{Recommended Citation}

Mang'oli, Wellington Sifuna, "Effects of fermenten during the dry and early lactation periods of dairy cows" (1999). Graduate Theses, Dissertations, and Problem Reports. 1033.

https://researchrepository.wvu.edu/etd/1033

This Thesis is protected by copyright and/or related rights. It has been brought to you by the The Research Repository @ WVU with permission from the rights-holder(s). You are free to use this Thesis in any way that is permitted by the copyright and related rights legislation that applies to your use. For other uses you must obtain permission from the rights-holder(s) directly, unless additional rights are indicated by a Creative Commons license in the record and/ or on the work itself. This Thesis has been accepted for inclusion in WVU Graduate Theses, Dissertations, and Problem Reports collection by an authorized administrator of The Research Repository @ WVU. For more information, please contact researchrepository@mail.wvu.edu. 


\title{
Effects of Fermenten During the Dry and Early Lactation Periods in Dairy Cows
}

\author{
Wellington Sifuna Mang'oli, B.S. Agric., Dip. An. Husb.
}
Thesis Submitted to the College of Agriculture and Forestry at West Virginia University In partial fulfillment of the requirements of

\author{
Masters of Science \\ in \\ Animal and Veterinary Sciences \\ W. H. Hoover, Chair \\ Edward C. Prigge \\ John Killefer
}

1999

Morgantown, West Virginia

Keywords: Fermenten, Anionic Salt, Prepartum, Postpartum, Diary Cows, Dry Period, Transition Period 


\title{
Effects of Fermenten During the Dry and Early Lactation Periods of Dairy Cows
}

\author{
Wellington Sifuna Mang'oli
}

\section{(ABSTRACT)}

Fermenten is a commercially available by-product of lysine production recommended by the manufacturer (Biovance Technologies Inc., Omaha, NE) as a protein source for growing heifers and lactating cows. It has not been used in the diets of dry cows within 4 weeks of parturition. Three groups of 10 cows each, balanced for breed (Ayrshire and Holstein) and parity, were assigned to diets containing $0,0.73$ and $1.45 \mathrm{~kg}$ Fermenten dry matter/day. The diets were fed from 4 weeks prior to expected calving through 6 weeks of lactation. Dry matter intake of all diets decreased prior to calving, with the treatments significantly $(\mathrm{P}<0.05)$ lower than the control diet. Decline in intake between wk 2 and wk 1 prepartum was $3.6 \%, 20.4 \%$ and $15.8 \%$ for the control, low and high Fermenten diets, respectively. Postpartum nutrient intakes increased for all diets with treatments significantly $(\mathrm{P}<0.05)$ lower than the control at week one and marginally lower $(\mathrm{P}<0.10)$ for weeks 2 through 6 . Intake of NDF was below $1 \%$ of body weight up to 4 weeks postpartum for all groups. Milk yield was significantly $(\mathrm{P}<0.05)$ depressed by Fermenten (6.50 and $5.95 \mathrm{~kg} / \mathrm{d}$ for low and high levels, respectively). Milk fat and protein percentages were not affected by diets. Body weight and body condition score at calving were significantly decreased by Fermenten $(\mathrm{P}<0.05)$. Fermenten contains anionic salts, and was found to reduce urine $\mathrm{pH}$. Cows fed Fermenten had a higher incidence of metabolic disorders. Based on these results, Fermenten is not recommended in the diets of close-up dry cows.

Keywords: Fermenten, Anionic salts, prepartum, postpartum, Dairy cows, dry period, transition period. 


\section{ACKNOWLEDGEMENTS}

First and foremost, I thank God for having blessed me with good health for the entire study period, and I praise Him for that. My heartfelt thanks and appreciation goes to Dr. William H. Hoover my advisor and chairman of my committee. Dr Hoover took the initiative to see to it that the study goes on as planned. His guidance and expertise made me learn a lot in the field of dairy nutrition. Not only did Dr. Hoover take me just as a student, but also as a son. I am fortunate to have studied under such a reputable man in the field of animal science. Being his last student in his career, I am very grateful for that. Dr. Hoover, God bless you for all that you did for me.

I also extend my gratitude to Dr. Edward C. Prigge my undergraduate advisor and Dr. John Killefer for serving on my committee. Their valued advice when needed made this project a success.

Laboratory work could have been a nightmare were it not for Tammy Miller-Webster. I am very grateful to have worked under her guidance. She made sure I knew all procedures for sampling and analysis, all the feeding sheets for the study were made by her weekly. She made my working condition in the laboratory favorable all the time. Be blessed Tammy and do the same for any other student that will work under you.

I thank Dr. W.V. Thayne for the statistical analysis of the study. He was patient to listen to me and took his time to analyze my data with all the trouble I had in setting it up for him. Mr. Rick Wood the man on the ground where the study took place deserves special thanks. He undertook the day to day activities on the farm of training the cows, feeding them, mixing the feed, taking body weights, body condition scoring and sampling. This saved me of making daily trips to the farm so that I can work on the samples. Also my thanks go to all the dairy crew for the help they provided whenever I needed.

This report could not have been completed on time without the help of Sharon Earl. She took the pain of typing and put this document in the right order. I am indeed indebted to her generous support.

Last but not least, I extend my thanks to my family, and especially to my dear wife for giving me an off to come over for study. Their encouragement to keep on pressing has made me to accomplish this mission. 


\section{TABLE OF CONTENTS}

Page

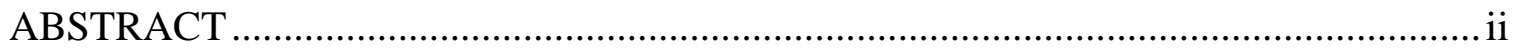

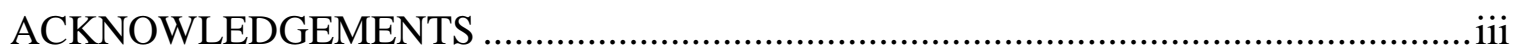

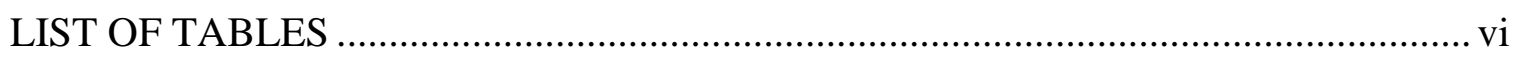

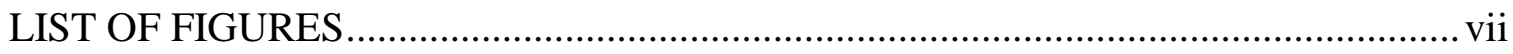

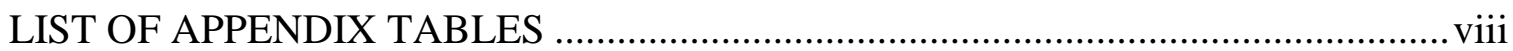

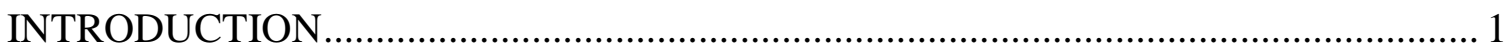

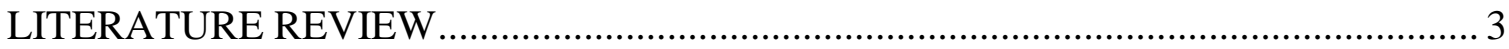

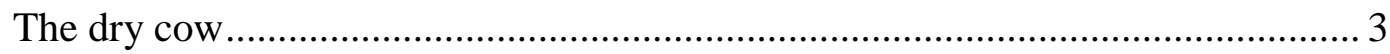

Nutrient Requirements and Dry Matter Intake................................................... 3

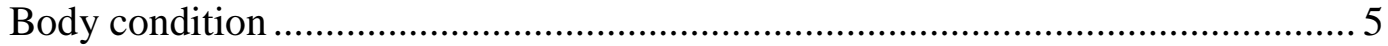

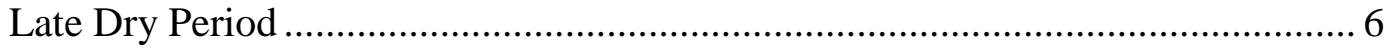

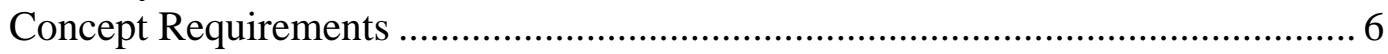

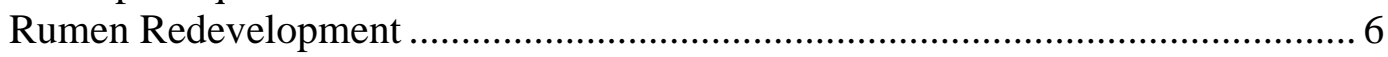

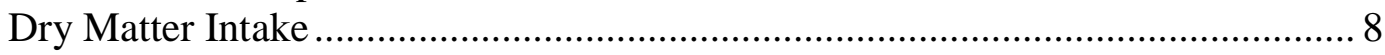

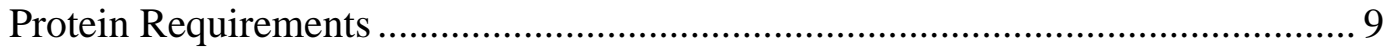

Metabolic Disorders .................................................................................... 11

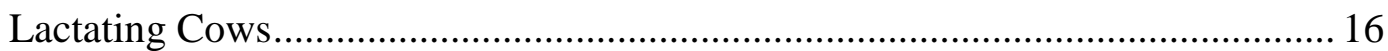

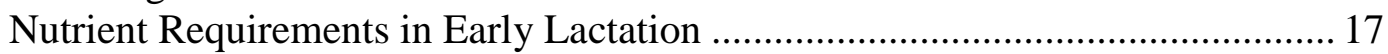

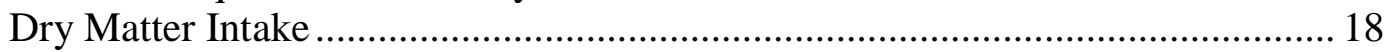

Growth of Rumen Microbes........................................................................... 19

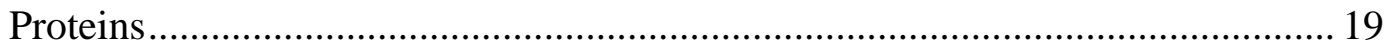

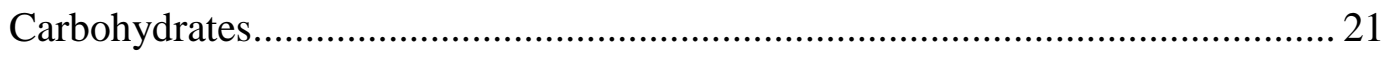

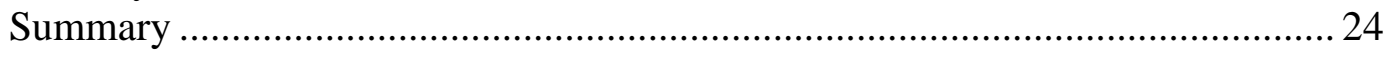

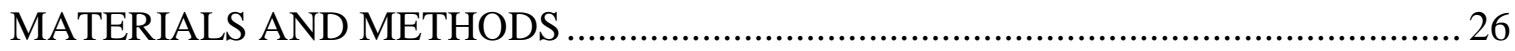

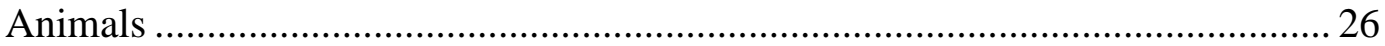

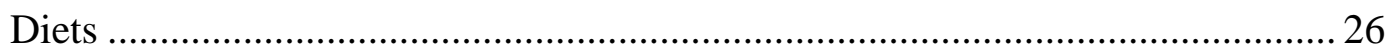

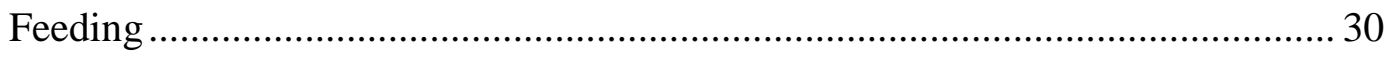

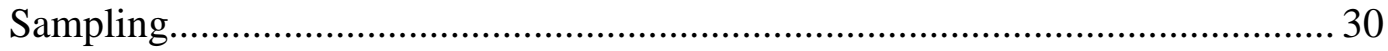

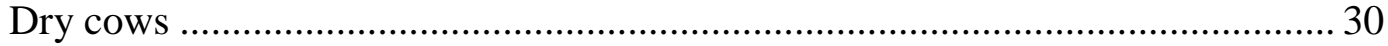

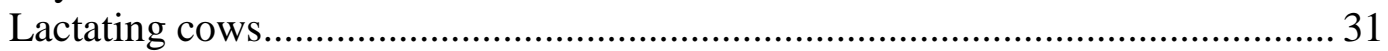

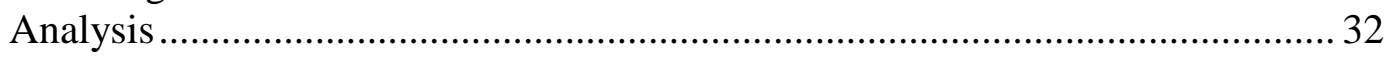

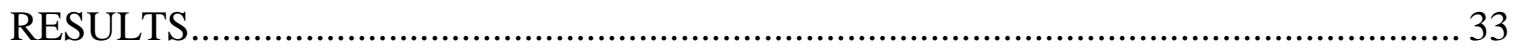

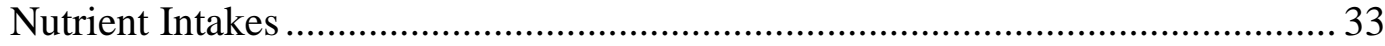


TABLE OF CONTENTS (Continued)

Page

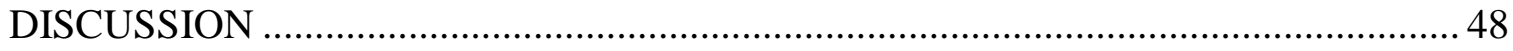

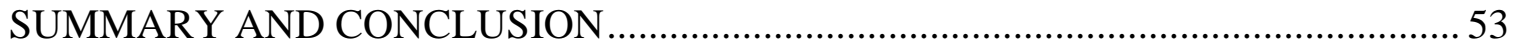

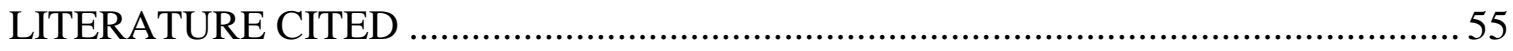

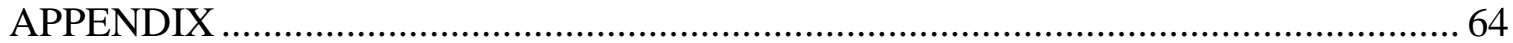

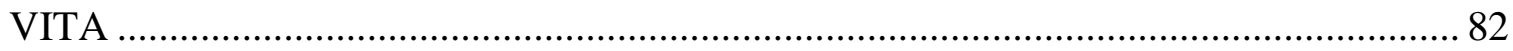

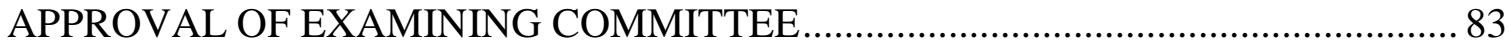




\section{LIST OF TABLES}

Table

Page

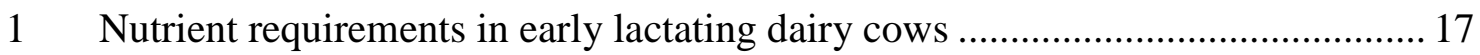

2 Nutrient Recommendations for dry and lactating cows ................................ 25

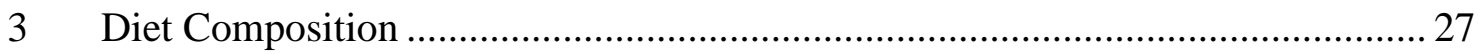

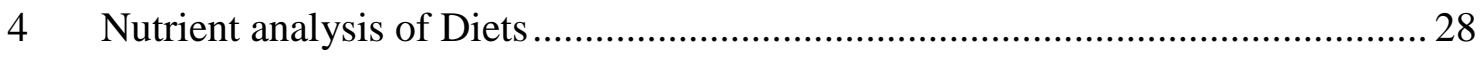

5 Composition of Fermenten (DM basis ....................................................... 29

6 Least square means for intake of dry matter (DM), crude protein (CP), neutral detergent fiber (NDF) and nonstructural carbohydrate (NSC)

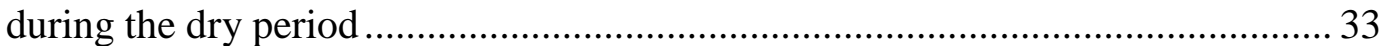

7 Percentage decreased in intakes of dry matter (DM), crude protein $(\mathrm{CP})$, neutral detergent fiber (NDF) and nonstructural carbohydrate (NSC) between weeks 2 and 1 prepartum

$8 \quad$ Intake differences between the control and treatments during the dry period, $\mathrm{kg} \mathrm{DM} / \mathrm{d}$

9 Least square means for intake of dry matter (DM), crude protein (CP), neutral detergent fiber (NDF) and nonstructural carbohydrate (NSC) for

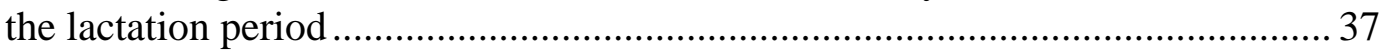

10 Intake of neutral detergent fiber (NDF) as percentages of body weight .............. 38

11 Least square means for lactation performance measures .................................. 39

12 Effect of treatments on body weight and body condition score ......................... 40

13 Effect of treatments on milk urea nitrogen (MUN ........................................ 42

14 Effect of treatments on metabolic disorders .................................................. 45

15 Effect of Fermenten on somatic cell count................................................... 46

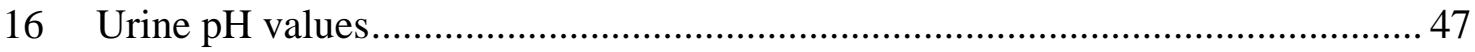

17 Nutrient intakes and recommendations during the week

prior to parturition 


\section{LIST OF FIGURES}

$\begin{array}{lll}\text { Figure } & \text { Page }\end{array}$

1 Dry matter intake, $\mathrm{kg} / \mathrm{d}$ before and after calving for all diets ........................... 35

2 Crude protein Intake, $\mathrm{kg} / \mathrm{d}$ before and after calving for all diets ........................ 36

3 Body condition score before and after calving .......................................... 41

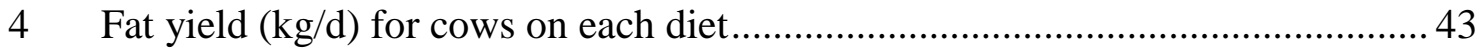

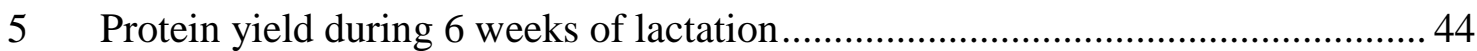




\section{LIST OF APPENDIX TABLES}

Table

Page

1 Effect of Fermenten on acid detergent fiber (ADF), organic matter (OM) and fat intake before and after calving

2 Effect of Fermenten on intake of starch and sugar before and after calving

3 Fat and protein yields $(\mathrm{kg} / \mathrm{d})$ during 6 weeks of lactation 66

4 Data used to calculate least square means of dry matter intake prepartum and 6 weeks postpartum

5 Data used to calculate least square means for milk yield for

6 weeks postpartum.

6 Data used to calculate least square means for $4 \%$

Fat corrected milk (FCM

7a Data used to calculate crude protein intake means before calving

7b Data used to calculate crude protein intake after calving.

8a Data used to calculate NDF intake 3 weeks prepartum 70

8b Data used to calculate NDF intake during lactation..................................... 70

9 Data used to calculate least square means for fat yield in milk 71

10 Data used to calculate fat percent in milk per cow for six weeks of lactation

11 Data used to calculate protein yield per cow per day during lactation period

12 Data used to calculate protein percent in milk per cow per day during lactation

13 Data used to calculate least square means for milk urea nitrogen (MUN

14 Data used to calculate least square means for somatic cell count (SCC) cells $/ \mathrm{ml}$ in milk. 


\section{LIST OF APPENDIX TABLES (Continued)}

Table

Page

15a Data used to calculate least square means for acid detergent fiber (ADF) intake in the dry period

15b Data used to calculate least square means for ADF intake during lactation.

16a Data used to calculate least square means for sugar intake in the dry period 75

16b Data used to calculate least square means for sugar intake in the lactation period 75

17a Data used to calculate least square means for nonstructural carbohydrate intake in the dry period.

17b Data used to calculate least square means for nonstructural carbohydrate (NSC) intake during lactation.

$18 \mathrm{a} \& \mathrm{~b}$ Data used to calculate least square means for organic matter intake $(\mathrm{kg})$ in the dry and lactation period

19a Data used to calculate least square means for fat intake during the dry period

19b Data used to calculate least square means for fat intake during lactation.

20a Data used to calculate least square means for starch intake in the dry period

20b Data used to calculate least square means for starch intake during lactation.

21 Data used to calculate least square means for NDF intake as percent of body weight

22 Data used to calculate least square means for body weight ( $\mathrm{kg}$.

23 Data used to calculate least squares means for body condition score 


\section{CHAPTER 1. INTRODUCTION}

Nutrient intake during the three-week period prior to calving is important not only for meeting the requirements of pregnancy, but also to prepare the cow for lactation. Preparation for lactation includes the building up of maternal reserves of nutrients, adaptation of rumen microbes for fermentation and adaptation of rumen epithelium for absorption of nutrients (Chalupa et al., 1997).

Recent studies have found declines in dry matter intake of as much as $30 \%$ as calving approaches (Grummer, 1995). Cows showing such decreases have been found to have higher incidents of metabolic disorders (Zamet et al., 1979), produce less milk (Bertics et al., 1992) and have lower dry matter intakes post-calving (Grummer et al., 1995).

New evidence of the importance of protein nutrition has also been demonstrated in the transition cow and sheep. Bell (1995) found that 56\% of fetal energy in the bovine was provided by maternal amino acids. McNeill et al., (1994) discovered that $16 \%$ crude protein diet was needed to prevent loss of protein from peripheral tissues to the gravid uterus in sheep. A decline in feed intake prepartum would negatively impact both dietary protein and energy status

The current practice of feeding anionic salts to prevent parturient paresis has been suggested to exacerbate the low intake problem because of the unpalatable nature of most anionic salts (Goff and Horst, 1996). BioChlor, a source of protein and anionic salts, (Biovance Technologies Inc, Omaha, NE) appears capable of addressing three of the dry cow problems. It has been found to increase microbial growth and efficiency in continuous culture of rumen contents (Hoover and Miller 1993; Miller et al., 1996). It has also been shown to increase intake 
and mobilize calcium in the late dry period, which reduced periparturient metabolic disorders and resulted in increased intake and milk production following parturition (Hoover et al., 1998). Vagnoni and Oetzel (1998) reported reduced DMI during the dry period with BioChlor feeding; however, their study was conducted for $7 \mathrm{~d}$ in the early dry period.

BioChlor is made from the fermentation residue from the production of monosodium glutamate and contains $8.6 \%$ chloride as the major anion. Fermenten, as a second product produced by Biovance Technologies, is made from the residue from the production of lysine, and is reported to contain $2.2-2.5 \%$ sulfur as a major anion, with less than 1-\% chloride. Fermenten should be considerably less anionic than BioChlor, and is currently sold as a growth promoter for young cattle, particularly dairy heifers. Fermenten has also been suggested to be used as a feed additive in lactating cows (Chalupa, 1997). Improved rates of gain in Fermenten-fed heifers may be due to a ruminal response, which should be of benefit to late dry cows (within 4 weeks of calving) in which rumen function must be enhanced in preparation for lactation. No studies on the use of Fermenten in the late dry period or the very early lactation period have been conducted. The objectives of this study were to investigate the effects of two levels of Fermenten fed to dairy cows during the late dry period and early lactation on dry matter intake, milk production and composition, and the incidence of metabolic disorders. 


\section{CHAPTER 2. LITERATURE REVIEW}

\section{THE DRY COW}

Dairy cows require a rest period between lactations. The udder and the digestive tract especially benefit from the dry period. The dry period is the best time to institute management practices to prevent health problems and to ensure high production during the subsequent lactation (Coppock, 1974). It is very important for cows to have a dry period of at least 8 weeks (Harris, Jr., 1992; Cote, 1992). The amount of milk produced during lactation is influenced by the length of the dry period (O'Connor, Jr. and Oltenacu, 1988). It has been reported that cows dry for 60 days gave approximately $114 \mathrm{~kg}$ more milk the following lactation than did cows dry for 50 days. Cows dry 40 days produced $225 \mathrm{~kg}$ less milk than cows with a 60 day dry period (Heinrichs et al., 1989). The dry period is necessary to allow the mammary gland to go through a normal period of involution and to ensure a normal proliferation of secretory cells at and following parturition.

\section{A. Nutrient Requirements and Dry Matter Intake}

In the publication "Nutrient Requirements of Dairy Cattle" (NRC, 1989), an increase over maintenance is recommended for energy, protein $\mathrm{Ca}$ and $\mathrm{P}$ for mature, pregnant cows. These daily increases are to be fed for the entire two-month dry period. For $\mathrm{NE}_{\mathrm{L}}, \mathrm{Ca}$ and $\mathrm{P}$, the daily increases, as percentages of maintenance, are 30, 62.5 and 41, respectively. Crude protein (CP) is increased from $406 \mathrm{~g} / \mathrm{d}$ at maintenance for a $600 \mathrm{~kg}$ cow, to $1074 \mathrm{~g} / \mathrm{d}$, a 1.64 fold increase. The proportionately larger increase for $\mathrm{CP}$ reflects the protein retention in the fetus and gravid uterus of cattle, which has been reported to increase 1.4 fold between weeks 30 and 38 of pregnancy (NRC, 1985). Although the increase over maintenance needed to allow for fetal growth seems large, actual daily nutrient requirements in the early dry period are easily met. 
Dry cows will consume 1.3 to $2.1 \%$ of live weight (Marquardt et al., 1977; Bertics et al., 1992). Nutrient densities recommended for early dry cows are: $\mathrm{NE}_{\mathrm{L}}, 1.1-1.2 \mathrm{Mcal} / \mathrm{Kg} ; \mathrm{CP}, 12-13 \%$ of DM; Ca $.31-.35 \%$ of DM and P .19 - .21\% of DM. Recent feeding recommendations (see table 2) for early dry cows that are not specified by the NRC (1989) are NDF at 60-65\% of ration DM and non-structural-carbohydrate (NSC), which includes sugars, starches and soluble fiber, at 20$25 \%$ of DM. Requirements specified above for $\mathrm{NE}_{\mathrm{L}}, \mathrm{CP}, \mathrm{NDF}, \mathrm{NFC}$ and minerals can easily be met by feeding good quality grass forage or a combination of legume forage and corn silage. Indeed, this is the general practice on many dairy farms.

In spite of the recommendation of the NRC (1989) to maintain this level of nutrient intake throughout the dry period, changes in physiological state and the need to prepare for the subsequent lactation have prompted dairymen to divide the dry period into at least two phases. Usually, there is the early dry period, which is the first 5 weeks, and late dry period often called the close-up period, the last 3 weeks prior to calving. 


\section{B. Body Condition.}

Body condition is used as a management tool to assess the energy reserves of cattle in any physiological state, including the dry cow (Ferguson et al., 1994). In dairy cattle, a fivepoint scale system developed by Wildman et al. (1982) is commonly used, with a score of one being very thin and five obese. Dry cows need sufficient reserves to support lactation upon calving, a time when dry matter intake (DMI) normally is low and body tissue is needed to support production. Cows with excessive condition at parturition, such as a BCS of $>4.0$, have low DMI, lose condition excessively and have more reproductive problems compared to cows with a BCS < 3.75 (Gearhart et al., 1990). Loss of condition during the dry period has been associated with a high incidence of dystocia (Morrow et al., 1979), thus excessive condition at drying off cannot safely be dealt with in the dry period. It is recommended that BCS at dryingoff, and therefore in the early dry period, should be between 3.0 and 3.75, and maintained at this score throughout the dry period (Ferguson, 1996). 


\section{Late Dry Period.}

The late dry period is described as the last 3-4 wks prior to parturition. It is characterized by a number of physiological changes that support altering the intake of several nutrients. Some of the changes that affect nutrient requirements are listed below.

\section{Conceptus Requirements.}

Requirements of the growing fetus are highest during this period (Quigley et al., 1998). The primary sources of energy for fetal growth are amino acids, lactic acid and glucose (Battaglia and Meschia, 1978). Other substrates include $\beta$-hydroxybutyric acid, acetate and free fatty acids, although their utilization by the fetus is very small (Faulkner, 1983). Bell et al. (1995) estimated rates of accumulation of protein, energy, fat and minerals by the gravid uterus and fetal tissue of pregnant Holstein cattle slaughtered between 190 and 270 days after conception. It was reported Bell (1995) by that $56 \%$ of the energy of the growing fetus was provided by amino acids, with $34 \%$ deposited as protein. Of the total nutrients taken up, the uteroplacental tissue rather than the fetus used the major quantity. This emphasized the need for increased nutrients in the late dry period, particularly protein.

\section{Rumen Redevelopment}

In the pre-ruminant calf, rumen development in terms of mucosal growth, muscle development and increase in rumen volume all are dependent on absorption of volatile fatty acids (VFA) by the rumen tissues (Sander et al., 1959; Nocek et al., 1984). Grain intake is most effective in promoting tissue growth, as the grains ferment to higher levels of propionate and butyrate and reduce rumen $\mathrm{pH}$ more than do forages. The reduction in $\mathrm{pH}$ greatly enhances uptake of VFA into rumen tissues (Dijkstra, 1994). 
In the mature cow, changes similar to those in the developing calf rumen occur in each dry period. In the early dry period when little or no grain is fed and nutrient demands are low, the rumen volume decreases papillae regress, microbial production of VFA is low and rumen $\mathrm{pH}$ is high. In order to prepare the rumen for the demands of late pregnancy, parturition and the subsequent lactation, it is important to initiate rumen redevelopment 3 to 4 weeks prior to parturition. This is accomplished by feeding a diet similar to a lactation ration in fermentable carbohydrates and ruminally available protein (Hoover and Miller-Webster, 1989). This practice has been shown to be effective in reducing metabolic disorders in periparturient cows. Curtis et al. (1985) analyzed 1374 lactation records separated into three feeding groups; a low energy and protein group, which was actually in excess of NRC (1978) recommendations, a medium group, with energy and protein fed at 180 and $150 \%$ of NRC recommendations respectively, and a high energy group with energy and protein at 224 and $178 \%$ of requirements. The mid group, given moderate amounts of grain and protein supplement, had significantly fewer incidences of retained placenta, milk fever, metritis and ketosis than the groups fed either low or high grain levels.

An additional advantage of grain feeding in the late dry period is to encourage growth of lactic acid utilizing bacteria, such as Megasphera elsdenii, in order to reduce the occurrence of lactic acidosis when the cow is placed on the high grain lactation ration. 


\section{Dry Matter Intake}

Dry matter intake is influenced by a variety of physical and reproductive factors including the space occupied by the fetus, rumen fill, fiber in the diet, excessive fat mobilization and blood ketone body levels. Nutrient requirements during the last month of gestation are high while dry matter intake declines as the cow approaches freshening. The decline has been reported by Bertics et al. (1992) and Van Saun et al. (1993) to be a 2 to $4 \mathrm{~kg} \mathrm{DM} / \mathrm{d}$ decrease, while Grummer (1995) and Zamet et al. (1979) reported decreases of as much as 30\% during the last 2 weeks of gestation. Since at very low DMI, requirements can not be met during the last few days of the dry period, the cow mobilizes its body reserves, especially fat, to meet the requirements (Clark and Davis, 1978). Cows showing great declines in DMI have been found to have a higher incidence of metabolic disorders (Zamet et al., 1979; Clark and Davis, 1978), produce less milk (Bertics et al., 1992) and have lower dry matter intakes post-calving (Grummer et al., 1995). As a result, the cow also may lose weight in late gestation (Roffler and Thacker, 1983; Heinrichs et al., 1989 and Kertz et al., 1997).

During the last two to three weeks prepartum, when DMI is naturally depressed, high levels of dietary NDF can further depress intake. Addition of some grain to an all-forage diet in the late dry period was reported by Curits et al., (1985) to significantly reduce metabolic disorders at parturition. Excessive grain, however, reduced rumen fill, depressed intake and reduced rumen motility (Shaver, 1997)

Apart from the stage of pregnancy causing a decline in DMI, the type or status of pregnancy can also affect intake. Compared with a single pregnancy, cows with a twin pregnancy have lower mean DMI, and the decline in intake is even earlier (5 weeks) prior to 
calving (Van Saun, 1993). Over conditioned cows at calving (BCS >3.5) had depressed DMI and, after calving, produced less milk, lost more body condition and had a greater incidence of retained placenta, mastitis and cystic ovaries (Harris, Jr. 1993).

\section{Protein Requirements.}

Considering that the fetus relies heavily on amino acids as both sources of energy and protein, it is clear that proper protein nutrition is critical. The prepartum cow receives amino acid from two sources. Microbial protein is the most important source and the most balanced. It is also the most consistently digestible source of protein. Rumen undegradable protein is the second source available to the ruminant animal. This pool plays an important supplemental role.

Although high requirements for protein and decreased DM intake would suggest a need for increasing the protein content of the ration, current recommendations (NRC, 1989) remain the same as for the early dry period. This may put the periparturient cow at risk of inadequate dietary protein. This possibility has led to a number of studies concerning both total and ruminally undegradable protein (RUP) levels for dry cows, with inconsistent results. Until the recent experiment of McNeill et al. (1994), ruminants were thought to have limited capacity to store protein. Ewes fed rations with $8 \%$ and $12 \%$ crude protein took protein from their peripheral tissues (skeletal muscle and skin) to meet requirements of the gravid uterus. At $16 \%$ dietary protein, there was accretion of protein in peripheral tissues, while protein deposition in organs and mammary tissue was increased when ewes were fed rations with either 12 or $16 \%$ crude protein.

A study by Komaragiri and Erdman (1997) was conducted with 20 Holstein cows to determine the effect of dietary protein on mobilization of body fat and protein. They fed diets containing either $16 \%$ or $19 \% \mathrm{CP}$, with $6 \%$ or $9 \%$ RUP, respectively. The experimental period 
was from -14 to $114 \mathrm{~d}$ postpartum. Body tissue loss occurred between wk 2 prepartum and wk 5 postpartum. Cows fed both treatments mobilized a mean of $54 \mathrm{~kg}$ of body fat and $21 \mathrm{~kg}$ of body protein. This confirmed the ability of cows to mobilize protein during periods of high requirements and inadequate intake.

Putnam and Varga (1998) fed multiparous Holstein cows dietary levels of 10.6, 12.7 or $14.5 \% \mathrm{CP}$ in the late dry period. A linear increase in N retention and in blood NEFA was noted when protein was increased from 10.5 to $14.5 \%$. Wu et al. (1997) fed cows a 14\% CP diet with either high $(41 \%)$ or low (34\%) ruminally undegradable protein for 30 days prepartum. They concluded that feeding the higher level of RUP did not affect subsequent lactational performance or milk composition. In a study by Van Saun et al., (1993) primigravid heifers were fed either 12.4\% CP, the level recommended by the NRC (1989), or a $15.3 \%$ CP diet with $61 \%$ RUP for a minimum of $21 \mathrm{~d}$ before calving. They reported that the higher level of protein improved postcalving BCS and milk protein percentage, but not milk production. Huyler et al. (1999) also found no effect on production of feeding diets with total and by-pass protein levels as percentages of DM of 11.7 and 3.1; 15.66 and 6.8, and 20.6 and 10.6, respectively. The diets were fed for six weeks pre-calving. In this study, the level of non fibrous carbohydrate (NFC) was apparently $<25 \%$, and decreased as protein was increased. In addition, the level of degradable protein was $<10 \%$ of DM in all but the high protein diet. It is speculated that in all diets, digestible carbohydrates were too low to support maximum microbial growth, with the same being true for ruminally available protein in the 11.7 and $15.6 \%$ protein diets. Failure to find responses to total or by-pass protein in dry cow diets may in some studies have been associated with the diet composition relative to the requirements for protein and carbohydrates needed for microbial growth. 
In the late dry period, when DMI is low, there may be merit to feeding practices that increase the efficiency of microbial growth, permitting more microbial protein production per unit of digested organic matter. Yeast and products that contain spent microbial cells, such as BioChlor and Fermenten (Biovance Technologies Inc. Omaha NB) have been shown to increase microbial efficiency in continuous cultures of rumen contents (Hoover and Miller, 1993; Hoover, Miller and Thayne, 1994). Results of feeding yeast in the dry period on lactation performance has shown both positive (Wohlt et al., 1991) and negative responses (Robinson, 1997; Soder and Holden, 1999). Both DMI and milk production were increased when BioChlor was fed for two weeks pre-calving (Miller et al., 1996).

\section{Metabolic Disorders.}

These disorders include milk fever, ketosis, fatty liver syndrome, retained placenta, displaced abomasum, dystocia, udder edema, metritis and mastitis (Zamet et al., 1979; Heinrichs, 1989; Kaneene et al., 1997). The major metabolic disorders that affect periparturient cows are usually the result of nutrition and feeding management problems. Body condition during the dry period can be an indicator of cows that are likely to have disorders. Fat cows and thin cows both fall into this category. Cows that have had milk fever are more susceptible to other disorders such as mastitis, displaced abomasum, retained placenta and ketosis (Goff and Horst, 1996).

Intakes of calcium, magnesium and potassium have been associated with many of the metabolic disorders. Low blood calcium has been associated mostly with milk fever; however, subclinical hypocalcemia also may be responsible for retained placenta and displaced abomasum (Goff and Horst, 1996). In milk fever, blood calcium levels can drop to $5 \mathrm{mg} / \mathrm{dl}$ or lower (Goings et al., 1974). Heinrichs et al., (1989) reported the decline in blood calcium levels from 
normal to severe milk fever as follows: normal lactating cow 8.4-10.2 mg/dl; normal at calving, 6.8-8.6 mg/dl; slight milk fever, 4.9-7.5 mg/dl; moderate milk fever, 4.2-6.8 mg/dl; and severe milk fever, $3.5-5.7 \mathrm{mg} / \mathrm{dl}$.

A study was conducted by Goings et al., (1974) to investigate the effect of low dietary calcium on milk fever. Two diets were fed a Control, fed throughout the dry period, provided $51 \mathrm{~g} \mathrm{Ca} / \mathrm{d}$ and a treatment diet provided $8 \mathrm{~g} \mathrm{Ca} / \mathrm{d}$, and was fed during the last two weeks prior to calving. They reported none of the cows on the treatment ration was paretic while 5 cows fed the high $\mathrm{Ca}$ diet required treatment for milk fever. They also found out that calcium levels in plasma were reduced within $36 \mathrm{~h}$ of initiating the low $\mathrm{Ca}$ diet, but gradually increased to normal by $96 \mathrm{~h}$. The return to normal $\mathrm{Ca}$ was associated with an increase in plasma parathyroid hormone that caused release of calcium from bones. They concluded that consumption of a high calcium diet during the dry period increased the incidence of parturient paresis, while $\mathrm{Ca}$ restriction decreased the incidence.

Restriction of calcium has some disadvantages. Oetzel et al., (1991) suggested to not restrict $\mathrm{Ca}$ because it would limit legume intake in favor of corn silage, corn or other cereal grains. This may result in excessive fattening during the prepartum period, and increase the incidence of metabolic disorders.

Although high $\mathrm{Ca}$ diets have been implicated in causing milk fever for some time, recent studies suggest high potassium diets may be more critical than high Ca. Goff and Horst (1997) carried out a study in which they fed prepartum cows diets with either .5 or $1.5 \%$ Ca. At each Ca level, diets were prepared that contained 1.1, 2.1, and 3.1\% K. While Ca level had no effect, the incidence of milk fever was increased from 2 of 20 to 10 of 20 and 11 of 23 as K levels increased from 1.1 to 2.1 to $3.1 \%$, respectively. Blood and urine $\mathrm{pH}$ also was increased with 
increasing $\mathrm{K}$, suggesting that high $\mathrm{K}$ inhibited $\mathrm{Ca}$ resorption from bones as a result of metabolic alkalosis. Similar results were obtained when Na replaced the K. They concluded that dietary $\mathrm{Ca}$ concentration is not a major risk factor for milk fever. Dietary strong cations, especially $\mathrm{K}$, induces metabolic alkalosis in the prepartum dairy cow, which reduces the ability of the cow to maintain Ca homeostasis to prevent milk fever, dietary $\mathrm{K}$ content of the prepartum diet should be reduced.

Although feeding forages with low levels of $\mathrm{Ca}$ and $\mathrm{K}$ in the dry period is effective in reducing metabolic disorders at calving, many farms do not have forages with low $\mathrm{Ca}$ and $\mathrm{K}$. An alternative approach is to feed sources of anions, which reduce blood $\mathrm{pH}$ and increase blood Ca. The response appears mediated through increased levels of 1,25-dihydroxyvitamin D, which causes both increased Ca absorption and resorption from bone (Block, 1984; Goff et al., 1991; Joyce et al., 1997; Goff and Host, 1997).

Anion use in preventing milk fever was first reported as early as 1970 when Ender and Dishington (1970) found that feeding cows forages treated with sulfuric or hydrochloric acids reduced milk fever. Recent studies show that the anions $\mathrm{Cl}$ and $\mathrm{S}$ neutralize the major cations $\mathrm{Na}$ and K, reducing blood pH (Goff and Horst, 1996). Dietary cation anion difference (DCAD) is the balance between cations and anions in the diet. Although blood ions potentially involved in acid-base balance include $\mathrm{Ca}, \mathrm{K}, \mathrm{Na}, \mathrm{P}, \mathrm{Mg}, \mathrm{Cl}$ and $\mathrm{S}$, in early calculations of DCAD the formula used contained only $\mathrm{Na}, \mathrm{K}$ and $\mathrm{Cl}$. The low absorption of $\mathrm{Ca}$ and $\mathrm{Mg}$, the question of metabolism of $\mathrm{S}$ from organic sources and the relatively low influence of blood $\mathrm{P}$ in acid-base balance resulted in the elimination of these elements from early equations (Tucker et al., 1988). In later studies, Oetzel et al. (1991) and Tucker et al. (1991) reported S from an inorganic source to be as effective as $\mathrm{Cl}$ in affecting blood and urine $\mathrm{pH}$. Currently, the most common formula 
for calculating DCAD balance in meq/100 $\mathrm{g}$ diet $\mathrm{DM}$ is: $[(\% \mathrm{Na}$ in diet $\mathrm{DM} / 0.023)+(\% \mathrm{~K}$ in diet $\mathrm{DM} / 0.039)]-[(\% \mathrm{Cl}$ in $\operatorname{diet} \mathrm{DM} / 0.025+\% \mathrm{~S}$ in $\operatorname{diet} \mathrm{DM} / 0.016)]$.

Balancing rations to have a DCAD of 0 to $-15-\mathrm{meq} / 100 \mathrm{~g}$ DM for cows in the late dry period (2-3 weeks before calving) with mixtures of anionic salts such as $\mathrm{NH}_{4} \mathrm{Cl},\left(\mathrm{NH}_{4}\right)_{2} \mathrm{SO}_{4}$, $\mathrm{MgSO}_{4}, \mathrm{MgCl}_{2}$ and $\mathrm{CaCl}_{2}$ has been shown to be effective in reducing milk fever (Block, 1984; Oetzel and Barmore, 1993; Goff and Horst, 1996; Goff and Horst, 1998). Anionic salts, however, are unpalatable and can reduce DM intake, which should exacerbate the nutrient intake problems already prevalent at this time.

Oetzel and Barmore (1993) evaluated concentrate mixtures containing various anionic salts. They used 12 pregnant, nonlactating, pluriparous cows. Mean intake was higher for the control than for the treatments. Comparing the salts, concentrates containing $\mathrm{MgSO}_{4} \cdot 2 \mathrm{H}_{2} \mathrm{O}$ were consumed more completely than were concentrates containing $\mathrm{NH}_{4} \mathrm{Cl},\left(\mathrm{NH}_{4}\right)_{2} \mathrm{SO}_{4}$ or $\mathrm{CaCl}_{2}$. They suggested that for adequate intakes, anionic salts need to be mixed with large amounts of concentrates or forages.

Alfalfa is known to have high levels of calcium and is, therefore, not normally used as a prepartum feed. A study by Joyce et al., (1997) was conducted with 45 nonlactating Holstein cows during the last 3 weeks of gestation. Three diets were used, the control diet of grass hay with DCAD of +30 , a treatment diet of alfalfa with DCAD of +35 and treatment diet of alfalfa plus anionic salts with DCAD of -7 . Cows fed diets with DCAD of -7 had the lowest urine $\mathrm{pH}$, the highest concentration of $\mathrm{Ca}$ in the blood and consumed the most dry matter postpartum. Prepartum DM intake for the negative DCAD diet was lowest of the three groups, thus the results of this study on DMI agree with those of Tucker et al., (1991) that anionic salts decreased DMI. The negative DCAD diet also had the lowest incidence of metabolic disorders. Milk 
yield was not significantly improved with this diet even though DMI postpartum was high. From this study, it can be concluded that alfalfa can be used as a prepartum diet when supplemented with anionic salts. Since anionic diets increase losses of $\mathrm{Ca}$ in the urine prepartum (Wang and Beede, 1992; Hoover et., al., 1998), Ca intakes of 120 to $150 \mathrm{~g} / \mathrm{d}$ are recommended in the late dry period (Goff and Horst, 1996).

Monitoring urine $\mathrm{pH}$ is important in determining whether acidification has been achieved by the addition of anions (Jardon, 1995; Goff and Horst, 1998). A urine $\mathrm{pH}$ of 6.5 to 5.5 is desirable as it indicates better potential control of milk fever and improved blood calcium status at calving (Goff and Horst, 1996; Chalupa et al., 1997)

Anionic salts are not the only source of anions as, demonstrated by Ender and Dishington (1970). Goff and Horst, (1998) also have demonstrated the use of hydrochloric acid as a source of anions to decrease blood $\mathrm{pH}$. In this study, a group of non-pregnant non-lactating cows were fed diets with $\mathrm{HC} 1$ added. Both urine and blood $\mathrm{pH}$ were reduced with $24 \mathrm{~h}$. After removal of the diet with $\mathrm{HC} 1$, urine $\mathrm{pH}$ went back to normal in $48 \mathrm{~h}$. When $\mathrm{HC} 1$ was used in prepartum rations of Jersey cows, incidence of milk fever was significantly reduced, plasma $\mathrm{Ca}$ concentrations were higher after calving, and prepartum feed intake was higher for the treatment group than for the control. Since hydrochloric acid appeared more palatable than anionic salts, it may be an alternative to anionic salts in controlling the incidence of milk fever.

The use of BioChlor, an acidified fermentation by-product, is currently in use as an anion source. A study by Hoover et al., (1998) was done to investigate the effect of BioChlor in dry cow diets. The DCAD for the BioChlor ration was $-17.1 \mathrm{meq} / 100 \mathrm{~g}$. In this study, urine $\mathrm{pH}$ was reduced by the treatment diet when compared with control (6.92 vs 8.06) and prepartum feed intake was increased from 7.3 to $9.5 \mathrm{Kg} / \mathrm{d}$. Metabolic disorders were not completely 
eliminated by BioChlor, but cases of displaced abomasum, milk fever and retained placentas were significantly reduced. Cows having high intakes prepartum often will consume more feed postpartum and produce more milk (Chalupa et al., 1997). Cows fed BioChlor during the prefresh period had higher feed intake post-calving (14.25 vs $12.60 \mathrm{~kg} / \mathrm{d})$ and produced more milk ( 33.8 vs $26.10 \mathrm{~kg} / \mathrm{d}$ ) for the first four weeks of lactation. BioChlor was found to be an effective acidifier primarily due to the content of $\mathrm{NH}_{4} \mathrm{Cl}$. Since BioChlor contains microbial peptides and amino acids, the increase in DMI prepartum may have been due to the stimulation of microbial growth by the nitrogen fractions. Vagnoni and Oetzel, (1998) used BioChlor in one of the three anionic salt diets. The diets used contained either BioChlor, $\mathrm{MgSO}_{4} \cdot 7 \mathrm{H}_{2} \mathrm{O}+\mathrm{NH}_{4} \mathrm{Cl}$ or $\mathrm{MgSO}_{4} \cdot 7 \mathrm{H}_{2}+\mathrm{CaSO}_{4}$. The diets, along with a control containing no anionic salts, were fed for 7 days to cows in the early dry period. In contrast to the results of Hoover et al., (1998) they found all anionic diets, including the BioChlor diet, decreased DM intake compared to the control.

\section{LACTATING COWS}

\section{A. Nutrient Requirements in Early Lactation.}

Between calving and peak milk production is the most critical period in the life of a cow. A shortage of energy, protein, vitamins or minerals or an imbalance in their supply may subject the cow to nutritional stress resulting in metabolic disorders or decreased production. During this period, the high producing cow is not able to consume enough feed to supply the energy and protein needed for maximum milk production. The nutrient requirements expressed as proportions of dry matter, recommended by the NRC (1989) are in Table 1. 
TABLE 1. Nutrient requirements in early lactating Dairy Cows.

$\begin{array}{ll}\text { Nutrient } & \frac{\mathrm{NRC}}{1.67} \\ \mathrm{NE}_{\mathrm{L}} & 18-19 \\ \mathrm{CP}, \% \mathrm{DM} & 9.7-10.4 \\ \mathrm{DIP}, \% \mathrm{DM} & 6.3-7.2 \\ \mathrm{UIP}, \% \mathrm{DM} & 19-21 \\ \mathrm{ADF}, \% \mathrm{DM} & 25-28 \\ \mathrm{NDF}, \% \mathrm{DM} & ----- \\ \text { NSC, \%DM } & 3 \\ \text { Ether Extract, \%DM } & .66-.77 \\ \text { Ca, \% DM } & .41-.49 \\ \mathrm{P}, \% \text { DM } & \end{array}$




\section{B. Dry matter intake}

Dry matter intake remains low during early lactation when milk production is increasing. As a result, high producing cows rely on body reserves of fat and protein to meet their nutrient requirements; subsequently, the animals lose body condition and weight (Roffler and Thacker, 1983, Grant and Keown. 1990. Primiparous cows will lose less body weight than multiparous cows (Roffler and Thacker, 1983). Dry matter intake will peak about 8 to 12 weeks post partum, beyond the peak point of milk yield which is 2 to $4 \mathrm{wk}$. earlier (Roffler and Thacker, 1983, Grant and Keown, 1990, Harris, Jr. 1992). Dry matter intake is influenced by a variety of physiological and physical factors, including rumen volume, fiber level in the diet, excessive fat mobilization and blood ketone body levels. Excessive fat mobilization due to an energy deficit can cause metabolic disorders such as ketosis (Ferguson, 1996).

To enhance DMI during early lactation, cows should have a body condition score of 3.0 to 3.5 at calving. Cows above these levels have depressed dry matter intake, lose more body condition and become susceptible to metabolic problems (Ferguson, 1996). Anything that will increase dry matter intake should improve animal performance. If not feeding a total mixed ration, suggestions of feeding forage first then grain has been made (Grant and Keown, 1990). They said that forage would stimulate the production of more saliva, which enhances buffering capacity in preparation for the rapidly fermented grain. They also reported that feeding forage first has been shown to increase milk production and milk fat test. Other factors affecting DMI in early lactation include the level of DM intake during the last few days prior to calving. Grummer et al., (1995) and Hoover et al., (1998) reported a close association of high intake in the late dry period with intake post-calving. Increased nutrient densities in late dry cow rations have been associated with increased intake post-calving (Grummer, 1995). 


\section{Growth of Rumen Microbes.}

During early lactation when DMI is low and requirements of the cow are high, it is important that rumen fermentation is as efficient as possible, so that maximum utilization of the feed components is realized. As mentioned earlier, this is initiated through proper feeding of the late dry cow to assure rumen VFA production, papillary development and rumen capacity are reestablished relative to the early dry period. Proper microbial growth and metabolism will assure flow of nutrients from the rumen, such as microbial protein, VFA and vitamins. For these nutrient flows to be maximized, proper nutrient supplies for the rumen microbes are required. The major diet components used for microbial growth are ruminally available proteins and carbohydrates.

\section{Proteins}

The combined proteolytic activities of ruminal bacteria and protozoa result in rapid degradation of most feed proteins. (Hino and Russell, 1987; Wallace and Brammall, 1985). As degradation proceeds, peptides of various lengths appear in the rumen fluid, followed rapidly by free amino acids and ammonia (Broderick and Craig, 1989; Chen and Russell, 1989). Although most rumen microbes, particularly fiber digesters, can use ammonia as the sole $\mathrm{N}$ source (Bryant, 1974), growth of both fiber and starch digesting microbes is enhanced by amino acids and peptides (Russell, 1983; Griswold et al., 1996; Jones et al., 1998).

While the proportions of $\mathrm{NH}_{3}-\mathrm{N}$, peptides and amino acids required to maximize microbial growth have not been determined, the total amount of available protein (Degradable Intake protein or DIP) is positively associated with microbial efficiency. Microbial efficiency is defined as the $\mathrm{g}$ microbial $\mathrm{N}$ synthesized/kg of carbohydrate or organic matter digested in the rumen. A positive, linear relationship has been observed between dietary DIP and microbial 
efficiency (Hoover and Stokes 1991; Stokes et al. 1991b). While this relationship remained linear $(\mathrm{R}=.94)$ to a DIP level of $18 \%$ of $\mathrm{DM}$, practical ration formulation recommendations are for $11-12 \%$ of ration DM as DIP (Hoover and Miller, 1996). Because microbial protein is the major protein source for lactating cattle (Hoover \& Miller 1996) it is important that the ration program is such that a high efficiency of microbial growth is maintained, particularly in early lactation when intake is low. Madsen and Hvelpland (1988) reported microbial efficiency to vary from 131 to $306 \mathrm{~g}$ microbial $\mathrm{CP} / \mathrm{kg}$ carbohydrate digested due to variations in ration composition. In addition to total DIP, particular $\mathrm{N}$ fractions such as specific peptides may further increase microbial efficiency. This may explain the effects of yeast cells and other microbial by-products such as BioChlor or Fermenten on increases in microbial efficiency, numbers of total microbes and microbial protein yield (Hoover et al., 1994; Chalupa et al., 1997; Harrison et al., 1988). Chalupa (1997) reported on a study in which .6kg of soybean meal was replaced by $1.15 \mathrm{~kg}$ Fermenten in the diets of high-producing (>40 kg/d) cows. Although the diets were isocaloric and isonitrogenous, the cows fed Fermenten produced $2.4 \mathrm{~kg}$ more milk/d than the controls.

While microbial protein is the major protein source for the lactating cow, it is inadequate to meet the entire needs. Based on amino acid flows, $45-70 \%$ of the total requirements for lactation has been estimated as supplied by microbial protein (Hoover and Miller-Webster, 1996). As a result, in addition to the DIP needed for microbial growth, UIP sources must be included in the ration. Prepartum diets containing increased undegradable protein improved body condition score at calving through 6 weeks post calving, and increased milk protein percentage (Van Saun et al., 1993). To maximize milk production, 30 to $40 \%$ of total crude protein (CP) should be UIP (Grant and Keown, 1990; Hoover and Miller, 1995). Since proteins 
in forages and most oil meals are highly degradable in the rumen (60-80\%), other sources must be added. Sources of UIP are heated soybean meal, distillers grain, feather meal, blood meal and corn gluten meal. Feeding excessive DIP can result in deamination of the degradable protein to ammonia at a rate that exceeds microbial assimilation. While this does not usually result in ammonia toxicity, it does represent a waste of feed protein and can reduce milk production (Helmer and Bartley, 1971). Ammonia absorbed through the rumen wall is converted to urea by the liver and kidney, and the resulting blood urea nitrogen rapidly equilibrates in the milk. Milk urea nitrogen (MUN) can be used as a tool for monitoring the utilization of protein and nonprotein nitrogen in dairy cows (Roseler et al., 1993; Hof et al., 1997; Linn and Garcia, 1998). Although milk urea nitrogen reflects metabolism and use of DIP and UIP other factors such as energy intake, water intake, liver function and urinary output also affect MUN (Ferguson, 1996; Baker and Ferguson 1994). Decreased milk urea nitrogen suggests more efficient utilization of protein while high concentrations indicate loss of nitrogen (Roseler et al., 1993; Harris. Jr, 1995; Wilson et al., 1998). The average level of MUN is 14 $\mathrm{mg} / \mathrm{dl}$. Concentrations of MUN of less than $12 \mathrm{mg} / \mathrm{dl}$ or greater than $18 \mathrm{mg} / \mathrm{dl}$ reflects deficient or excess CP in the diet, respectively (Wilson et al., 1998; Roseler et al., Oltner et al., 1983).

\section{Carbohydrates}

Once the microbial efficiency is established at a high level by proper feeding of $\mathrm{N}$ containing compounds, the total daily yield of microbial protein will be dependent on the quantity of total carbohydrate fermented in the rumen per day. Carbohydrates in cattle diets are in two forms. 
Fibrous carbohydrates which contain cellulose, hemicellulose and other compounds such as lignin. This fraction is best measured as Neutral Detergent Fiber or NDF. Since the fibrous carbohydrates act more or less as the skeleton of the plant, they are often referred to as structural carbohydrates. Nonstructural carbohydrates or NSC are made up of sugars and starches. The NSC content of feeds can be chemically determined using an enzymatic technique. While the NDF and enzymatic methods help identify the carbohydrate content of forages and grains form a chemical standpoint, there are limitations. First, there are specific compounds that are not included in either assay, such as pectins, gums, $\beta$-linked glucans, and, in ensiled products, fermentation acids. These can be significant components of such feeds as beet pulp, alfalfa, soyhulls and silages. Second, the analytical procedure of NSC is difficult and time-consuming. A more practical alternative is to determine NSC by difference, using a formula such as: NSC = $100-(\% \mathrm{NDF}+\%$ Crude protein $+\%$ fat $+\%$ ash $)$. Unless otherwise noted, the NSC values referred to in this section will be the "difference" values. The optimum NSC levels for high producing cows are currently under investigation. Work at West Virginia (Stokes et al., 1991a) and Perdue (Eastridge et al., 1988) suggest that NSC at 20 to25\% of DM intake is insufficient to support high production. Recently, Clark et al.(1992) at Illinois summarized a number of studies on effects of level of organic matter digestion in the rumen on microbial growth. The greatest microbial growth, as measured by microbial protein production, corresponded to about $12 \mathrm{~kg}$ of $\mathrm{OM}$ digested in the rumen. In order to get that amount of OM digested the rumen, the diet DM needed to contain 30-40\% NSC. Nocek and Russell (1988) summarized a number of studies and found that when NSC was $35 \%$ of diet DM, milk production was maximized. Thus, microbial yield and milk production appears to be maximized at similar levels of NSC. Results of recent studies by Batajoo and Shaver (1994) are generally supportive of these 
recommendations. They concluded that, for cows producing over $40 \mathrm{Kg}$ of milk, the diet should contain more than $30 \%$ NSC, but found little benefit of $42 \%$ over $36 \%$ NSC. In addition to total starch level, the rate and extent of ruminal starch digestion also may affect the amount of a particular starch source that can safely be added to a diet. Herrera-Saldana et al., (1990) ranked the degradability of starch from various sources as follows: oats $>$ wheat $>$ barley $>$ corn $>$ milo.

Ruminal availability of starch also may be altered by processing methods, such as fine grinding and steam flaking. Results of lactation studies comparing starch sources with differing digestibilities are somewhat inconsistent. Herrera-Saldana and Huber (1989) reported higher milk production with a barley-cottonseed meal diet than with a milo-cottonseed meal diet, while McCarthy Jr., et al. (1989) found milk production higher in diets containing corn than those containing barley. Some of the variation in results may be related to the effects of rapidly degradable starch on ruminal digestion of fiber. Rapidly fermented starch such as steam flaked corn or barley, can reduce $\mathrm{pH}$ in the rumen and decrease fiber digestion. Thus, while NSC digested may be high the decreased amount of fiber digested can result in a similar quantity of total carbohydrate digested (NSC + NDF). This appears to have happened in the study by McCarthy Jr. et al., (1989).

Neutral detergent fiber (NDF) represents the total cell wall or fibrous carbohydrates, with the exception of pectins. Pectins, however, ferment rapidly compared to the other NDF components (Hall, 1994) so from this standpoint are more appropriately included in the NSC fraction (which they are when NSC is estimated by difference). Mertens (1985) reported a relationship between NDF content of the ration and DM intake. Based on his studies, high producing cows should be fed rations with only 27-28\% NDF. Another way to express NDF capacity is as a percent of body weight. Merten's (1985) work indicated that cows in early 
lactation would consume only .95 to $1.05 \%$ of body weight as NDF. Studies by Miller et al. (1990) support this conclusion.

It has been established that exceeding the recommended levels of either NDF or NSC will have negative effects on intake or production. The question is, how can the $\mathrm{kg}$ of carbohydrate digested per day be increased without increasing the level of NSC? One suggestion is to substitute sources of rapidly degradable NDF for slowly degradable sources such as in forages. Varga and Hoover (1983) found that some sources of NDF, such as in beet pulp and wheat midds, ferment nearly as rapidly as corn starch. Miller et al., (1990) reported when rapidly degraded sources of fiber from wheat by-products and beet pulp were substituted for more slowly degraded fiber, total milk production and milk protein production increased significantly. While animal health was not impaired in these short (10 week) experiments, further studies are needed to determine long-term effects. Intake of the rapidly degraded NDF was only slightly higher, as a percentage of BW, than the slowly degraded NDF. This indicated that, while the small-particle NDF may not promote rumination activity, it retains much of its bulk characteristics and contributes to rumen fill.

\section{SUMMARY}

The need to balance the diet to maximize rumen fermentation is greatest during the late dry period through peak lactation. Recognition of the need to balance diets for specific quantities of carbohydrates and degradable and undegradable protein, as well as energy and minerals, has led to recommendations in addition to those of the NRC (1989). The following list of recommendations is compiled from several sources. 
TABLE 2. Nutrient Recommendations for Dry and Lactating Cows ${ }^{\mathrm{a}}$

\begin{tabular}{llll} 
Component & Early dry & Late dry & Early lactation \\
\hline $\mathrm{NE}_{\mathrm{L}}, \mathrm{Mcal} / \mathrm{Kg}$ & $1.1-1.2$ & $1.4-1.6$ & $1.67-1.72$ \\
$\mathrm{CP} \% \mathrm{DM}$ & $12-13$ & $14-15$ & $18-19$ \\
$\mathrm{DIP} \% \mathrm{DM}$ & $8-9$ & $9.5-10.5$ & $11-12$ \\
$\mathrm{UIP} \% \mathrm{DM}$ & $3-5$ & $5-6$ & $5-7$ \\
$\mathrm{NDF} \% \mathrm{DM}$ & $60-65$ & $32-36$ & $28-32$ \\
$\mathrm{NSC} \% \mathrm{DM}$ & $20-25$ & $35-40$ & $34-36$ \\
\hline
\end{tabular}

${ }^{\mathrm{a}}$ Compiled from the following sources:

NRC (1989)

Mertens (1985)

Van Saun and Sniffen (1993)

Grummer and Minor (1996)

Eastridge et al (1988)

Stokes et al (1991a)

Batajoo and Shaver 1993 


\section{CHAPTER 3. MATERIALS AND METHODS}

\section{ANIMALS}

Thirty Holstein and Ayrshire dairy cattle (Multiparous and Primiparous) were assigned by breed and parity to six diets with different levels of Fermenten. The feeding period for each animal was from four weeks prior to calving through six weeks post-calving. There were three groups, each having 10 animals.

When first assigned to the project, body weight was taken and a body condition score recorded. The scale used was from 1 to 5 developed by Wildman et al. (1982). Body weight also was taken at calving. Thereafter, body weights and condition scores were measured and recorded every 2 weeks to 6 weeks post-calving. Since calving dates of the 30 cows differed, the entire project was predicted to require 6 month.

\section{$\underline{\text { DIETS }}$}

Six diets were formulated, three for the dry period and three for the lactating cows. The three dry cow diets were the dry control (DC) with no Fermenten, a low Fermenten diet (DA) providing $0.73 \mathrm{~kg}$ Fermenten DM/day and a high Fermenten diet (DB) providing $1.45 \mathrm{~kg}$ Fermenten DM/day. The lactating (L) cow diets were formulated to provide the same amounts of Fermenten per day as for the dry cows, and were designated as LC, LA and LB, respectively. Composition and analysis of the diets are presented in Tables 3 and 4, respectively.

The rationale for feeding specific quantities of Fermenten $(0.73$ or $1.45 \mathrm{~kg} / \mathrm{cow} /$ day $)$ rather than constant percentages of the DM was based on the composition of Fermenten as shown in Table 5. 
TABLE 3. Diet composition

Diets $^{1}$

\begin{tabular}{|c|c|c|c|c|c|c|}
\hline Ingredients & DC & $\mathrm{DA}$ & DB & $\mathrm{LC}$ & LA & LB \\
\hline & \multicolumn{6}{|c|}{ 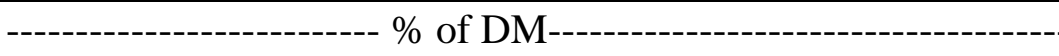 } \\
\hline Orchard grass hay & 48.3 & 47.41 & 46.55 & ---- & ---- & ---- \\
\hline Fermenten & 0 & 6.90 & 13.79 & 0 & 3.45 & 6.86 \\
\hline Beet pulp dehy. & 14.23 & 12.93 & 11.64 & ---- & ---- & ---- \\
\hline Ground barley & 4.31 & 4.31 & 4.31 & 12.17 & 11.81 & 11.80 \\
\hline Ground corn & 21.56 & 19.83 & 18.1 & 22.11 & 23.63 & 25.18 \\
\hline Urea & 0.60 & 0.30 & 0 & 0.15 & 0.13 & 0.13 \\
\hline Soybean meal 48 & 5.39 & 5.39 & 5.39 & 6.44 & 6.44 & 6.43 \\
\hline PROT.WP-2 ${ }^{2}$ & 5.39 & 2.72 & 0 & 4.08 & 2.15 & 0.43 \\
\hline TM-Salt & 0.22 & 0.22 & 0.22 & 0.43 & 0.43 & 0.43 \\
\hline Orchard grass hay & ---- & ---- & ---- & 20.18 & 18.04 & 22.09 \\
\hline Haylage & ---- & ---- & ---- & 27.47 & 26.85 & 19.30 \\
\hline Molasses cane dehy. & ---- & ---- & ---- & 6.44 & 6.44 & 6.43 \\
\hline Limestone & ---- & ---- & ---- & 0 & 0.11 & 0.39 \\
\hline $\mathrm{Ca} 23 \%: \mathrm{P} 18 \%$ & ---- & ---- & ---- & 0.43 & 0.43 & 0.43 \\
\hline Magnesium Oxide & ---- & ---- & ---- & 0.11 & 0.11 & 0.11 \\
\hline
\end{tabular}

${ }^{1}$ Diets: $\mathrm{DC}=$ dry cow control no Fermenten, DA = Dry $0.73 \mathrm{~kg}$ Fermenten DM/d, DB = dry 1.45 $\mathrm{kg}$ Fermenten DM/d, LC = lactation control, LA = lactation 0.73 Fermenten DM/d, LB = lactation $1.45 \mathrm{~kg}$ Fermenten DM/d

${ }^{2}$ By-pass protein source: Southern States Coop., Richmond VA 
TABLE 4. Nutrient analysis of diets

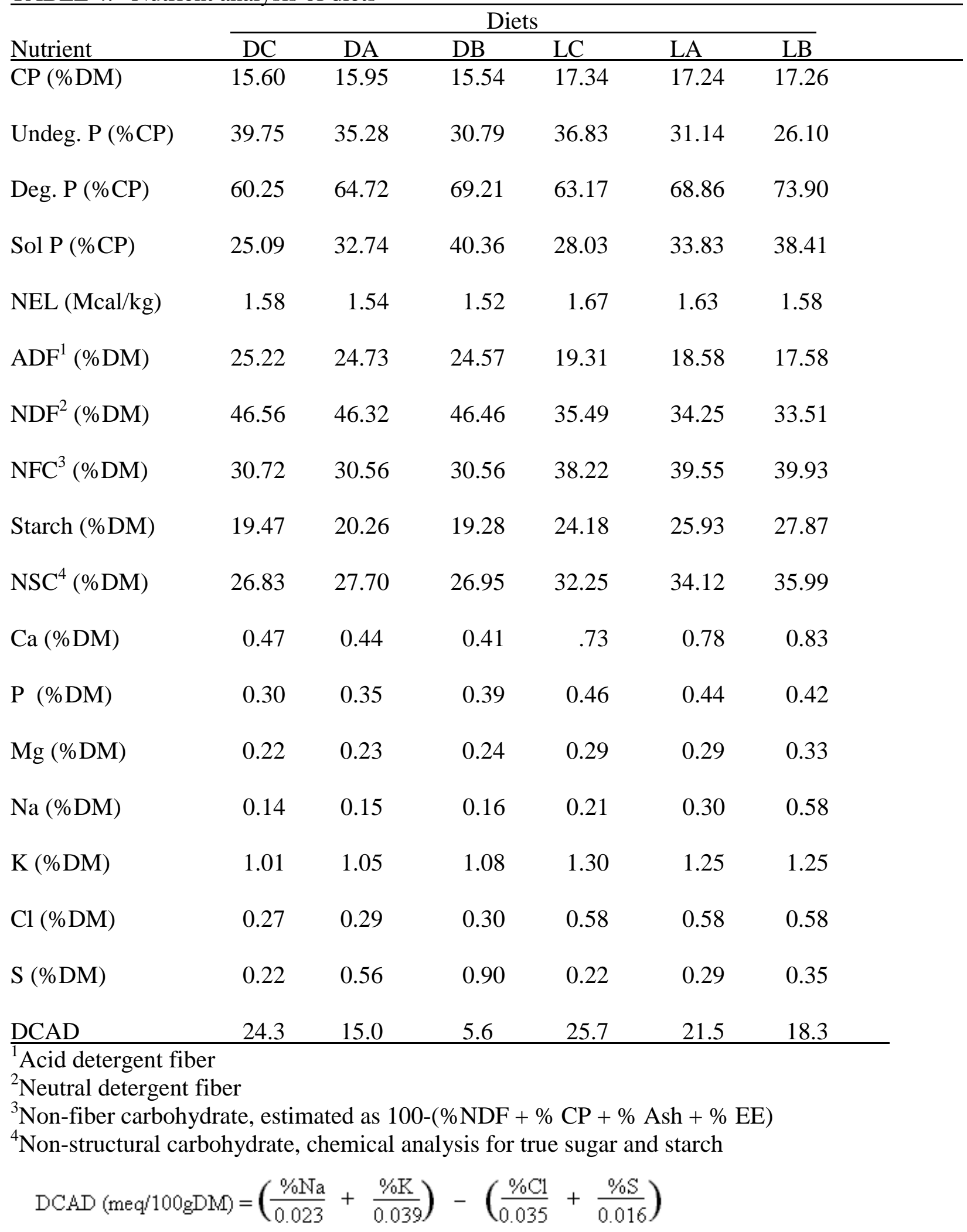


TABLE 5. Composition of Fermenten ${ }^{1}$, DM basis

Component

Dry Matter (\%)

Crude Protein, \% DM

Crude Protein as NPN, \% DM

Soluble Protein, \% DM

Ether extract, \% DM

Acid Det. Fiber, \% DM

TDN, \% (Est.)

NEL Mcal/kg (Est.)

$\mathrm{Ca}, \% \mathrm{DM}$

P, \% DM

$\mathrm{Mg}, \% \mathrm{DM}$

$\mathrm{K}, \% \mathrm{DM}$

S, \% DM

$\mathrm{Na}, \% \mathrm{DM}$

Chloride (\%)

${ }^{1}$ Data provided by Biovance Technologies Inc. Omaha, NE
$\%$

90.00

50.00

28.00

68.00

2.21

34.00

7.61

75.9

1.63

0.17

0.91

1.35

2.44

1.35

0.18

The concern about the inclusion of Fermenten was relative to the anionic salt content. While $\mathrm{Cl}$ was low, $\mathrm{S}$ was higher than in most natural ingredients at $2.44 \%$ of DM. This posed a possible problem for both the dry and lactating cows. If the DCAD of the dry cow diets was low enough to cause an acidifying effect, then the dry cow diets would have to provide $150-200 \mathrm{~g} \mathrm{Ca} / \mathrm{d}$. If there was little acidification, the high $\mathrm{Ca}$ would probably cause metabolic disorders. Immediately after freshening, the diet should have a DCAD of approximately 20 meq/100g DM. 
By holding the Fermenten constant, as the cows freshened and intake increased, the Fermenten would be diluted to about half the concentration of that of the dry cows, allowing the DCAD to become more positive.

The DCAD of the total mixed rations (TABLE 4) shows that, in the dry cows, it was low but not negative, so it was decided to formulate for low $\mathrm{Ca}$ as recommended when non-anionic diets are fed. The lactating cow diets all had reasonable DCAD values.

\section{FEEDING.}

Animals were fed individually using the Calan Head Gate System (American Calan, Inc., Northwood, $\mathrm{NH}$ ). The feed was provided once daily as a total mixed ration and was available to the cow 24 hours. Cows also were given water ad libitum. The feed was weighed daily, put in the feed box and mixed. All the hay used was chopped before being mixed with the grain.

Cows assigned to a specific diet in the dry period were continued on the same treatment post calving, i.e., control dry (DC) to control lactating (LC).

\section{SAMPLING.}

\section{Dry Cows.}

Orts for each cow were recorded daily and samples taken twice a week (Monday and Friday) for analysis. A factor of $10 \%$ was used in sampling; for example, if a cow left $3000 \mathrm{~g}$ of feed, then $300 \mathrm{~g}$ was retained and the rest discarded. Ort samples were then composited and frozen for the period.

At parturition, the percent dry matter of the orts composite for the dry period was determined by drying at $110^{\circ} \mathrm{C}$ and was used to determine the daily dry matter intake (DMI) during the dry period. The remaining samples were dried at $65^{\circ} \mathrm{C}$ and ground in a Wiley Mill 
(Arthur H. Thomas Co., Philadelphia, PA) to pass through a $1 \mathrm{~mm}$ screen. The ground samples were saved for analysis.

Samples of the chopped round bale hay were taken weekly, DM determined for feeding purposes and a $100 \mathrm{~g}$ sample was composited for 3 consecutive weeks, ground through $1 \mathrm{~mm}$ screen and stored for analysis. Samples of the grain mixes were taken at each mixing. Dry mater was determined for feeding purposes and a portion was ground through a $1 \mathrm{~mm}$ screen and stored for analysis.

\section{Lactating cows.}

Feed intakes and milk production were recorded daily. Ort samples were taken every week, composited and frozen. At the end of the 6 week treatment period, the percent DM of the composited samples was determined, recorded and used for determining the DM intake. The rest was dried at $65^{\circ} \mathrm{C}$ for at least $24 \mathrm{~h}$, ground through a $1 \mathrm{~mm}$ screen and saved for analysis. Grain mixes for lactation were sampled the same way as for dry cows.

Haylage and chopped square bale hay were sampled weekly and percent DM determined for feeding purposes. Samples of $100 \mathrm{~g}$ were composited for six consecutive weeks. The hay was ground as for the dry cows but the haylage was frozen and dried at $65^{\circ} \mathrm{C}$ before being ground through a $1 \mathrm{~mm}$ screen for analysis. Milk samples were taken at 7 days interval for two consecutive milkings and sent to the DHIA lab for protein, fat, somatic cell counts (SCC) and milk urea nitrogen (MUN) determinations (Mid-East DHIC, 1040 Fredrick Street, Hagerstown, MD 21740). 


\section{ANALYSIS}

Samples of the dried ground diet components were analyzed for CP using the Kjeldahl method (Tecator Kjeltec 1030 auto Analyzer). Acid and neutral detergent fiber were determined using ANKOM auto fiber analyzer (ANKOM Technology Corp., 140 Turk Hill Park, Fairport, NY 14450, 1997). Non-structural carbohydrates were determined by the reducing sugar method of Smith (1969) except that ferricyanide was used to detect reducing sugar. Analysis of ether extract was done according to AOAC utilizing the SOXTEC System HT Tecator 1043 extraction unit. Ash, dry matter and organic matter were determined according to AOAC procedures.

The experimental data was analyzed by the General Linear Models of SAS for analysis of variance for weekly group means. Contrasts were used to compare treatments versus control, high levels of Fermenten verses low. 


\section{CHAPTER 4. RESULTS}

$\underline{\text { Nutrient Intakes }}$

Intakes of DM, CP, NDF and NSC during the dry period are reported in Table 6. Due to missing data, least square means are presented.

At 3-wk prepartum, after 1 wk or less on the experimental diets, dry matter intake on both Fermenten treatments was significantly lower than for cows fed the control diet. Intake of the

TABLE 6. Least square means for intake of dry matter (DM), crude protein (CP), neutral detergent fiber (NDF) and nonstructural carbohydrate (NSC) during the dry period.

\begin{tabular}{|c|c|c|c|c|c|c|}
\hline \multirow[b]{3}{*}{ Item } & \multirow{3}{*}{$\begin{array}{l}\text { Weeks } \\
\text { relative to } \\
\text { calving }\end{array}$} & \multirow{2}{*}{\multicolumn{3}{|c|}{ Diets $^{2}$}} & \multicolumn{2}{|c|}{ Contrasts } \\
\hline & & & & & \multirow[t]{2}{*}{$\begin{array}{l}\text { Control vs } \\
\text { treatment }\end{array}$} & \multirow[t]{2}{*}{$\begin{array}{l}\text { high vs } \\
\text { low }\end{array}$} \\
\hline & & Control & Lowferm & Highferm & & \\
\hline & & \multicolumn{3}{|c|}{--------------kg/d--------------- } & \multicolumn{2}{|c|}{------------P----------- } \\
\hline Dry matter & -3 & 12.13 & 9.39 & 7.56 & $* * *$ & $*$ \\
\hline \multirow[t]{3}{*}{ Intake } & -2 & 11.07 & 9.54 & 7.85 & $* *$ & ---- \\
\hline & -1 & 10.67 & 7.59 & 6.61 & $* * *$ & ---- \\
\hline & Mean & 11.29 & 8.84 & 7.34 & $* * *$ & --- \\
\hline \multirow[t]{4}{*}{ CP intake } & -3 & 1.97 & 1.57 & 1.10 & $* * *$ & $* * *$ \\
\hline & -2 & 1.81 & 1.59 & 1.14 & $* *$ & $*$ \\
\hline & -1 & 1.79 & 1.32 & 0.92 & $* * *$ & $*$ \\
\hline & Mean & 1.86 & 1.49 & 1.05 & $* * *$ & $*$ \\
\hline \multirow[t]{4}{*}{ NDF intake } & -3 & 5.45 & 4.12 & 3.60 & $* * *$ & ---- \\
\hline & -2 & 4.91 & 4.24 & 3.78 & $*$ & ---- \\
\hline & -1 & 4.64 & 3.23 & 3.20 & $* * *$ & ---- \\
\hline & Mean & 5.00 & 3.86 & 3.53 & $* * *$ & ---- \\
\hline \multirow[t]{4}{*}{ NSC intake } & -3 & 3.44 & 2.82 & 1.96 & $* * *$ & $* * *$ \\
\hline & -2 & 3.17 & 2.84 & 2.03 & $* *$ & $* *$ \\
\hline & -1 & 3.15 & 2.41 & 1.66 & $* * *$ & $*$ \\
\hline & Mean & 3.25 & 2.69 & 1.88 & $* * *$ & $*$ \\
\hline
\end{tabular}

${ }^{2}$ Diets: control $=$ no Fermenten, Lowferm $=0.73 \mathrm{~kg}$ Fermenten DM/d,

Highferm $=1.45 \mathrm{~kg}$ Fermenten DM/d.

$* * * \mathrm{P}<0.01$

$* * \mathrm{P}<0.05$

$* \mathrm{P}<0.10$ 
high Fermenten diet was marginally $(\mathrm{P}<0.10)$ lower than that of the low Fermenten diet. Intakes of DM for the Fermenten treatments in week 2, while still lower than the control $(\mathrm{P}<0.05)$, did not decrease below that of wk 3. Between wk 2 and wk 1, which is the most critical period for decreasing intakes in prepartum cows, the intakes of the control cows declined by $3.6 \%$, while cows on the low and high Fermenten diets experienced decreases of $20.4 \%$ and $15.8 \%$, respectively.

Intakes of $\mathrm{CP}, \mathrm{NDF}$ and NSC reflected the DM intake. When the percentage decreases in DM and nutrient intakes between wk 2 and 1 were compared, (Table. 7) there were no indications that sorting of the forage and grain portions of the diet took place. Crude protein and NSC, which reflected the concentrate portions of the diets, had intake declines similar to NDF, which was mostly provided by the forage.

TABLE 7. Percentage decreased in intakes of dry matter (DM), crude protein (CP), neutral detergent fiber (NDF) and non-structural carbohydrate (NSC) between weeks 2 and 1 prepartum $^{1}$

\begin{tabular}{|c|c|c|c|}
\hline \multirow[b]{2}{*}{ Item } & \multicolumn{3}{|c|}{ Treatments } \\
\hline & Control & Lowferm & Highferm \\
\hline DM & 3.6 & $\begin{array}{c}\text { ecreases, } \\
20.4\end{array}$ & ---------- \\
\hline $\mathrm{CP}$ & 1.1 & 17.0 & 19.3 \\
\hline NDF & 5.5 & 23.8 & 15.3 \\
\hline NSC & 0.6 & 15.1 & 18.2 \\
\hline
\end{tabular}

${ }^{1}$ WK 2 intake - WK 1 intake

WK 2 intake

From both the weekly and mean DM intakes for the control and two levels of Fermenten over the dry period, as shown in Table 6, the intake responses between the two levels of Fermenten did not differ statistically. Numerically, however, there was a marked difference in intake depression between the two treatment levels during this period, as shown 
TABLE 8. Intake differences between the control and treatments during the dry period, $\mathrm{kg}$ DM/d Weeks Diet Comparisons

\begin{tabular}{ccc}
\cline { 2 - 3 } Pre-calving & Control - Lowferm & Control - Highferm \\
\hline-3 & 2.74 & 4.57 \\
-2 & 1.53 & 3.49 \\
-1 & 3.08 & 4.06 \\
Mean & 2.45 & 4.04 \\
\hline
\end{tabular}

in table 8. Intake of the high Fermenten diet appeared much more depressed than did intake on the low Fermenten diet, suggesting a component in Fermenten was depressing intake in a doseresponse manner.

Dry matter intake for the entire study is shown graphically in Figure 1. This permits visualization of the characteristic decline in intake for all diets as parturition approached, and the rapid recovery after calving.

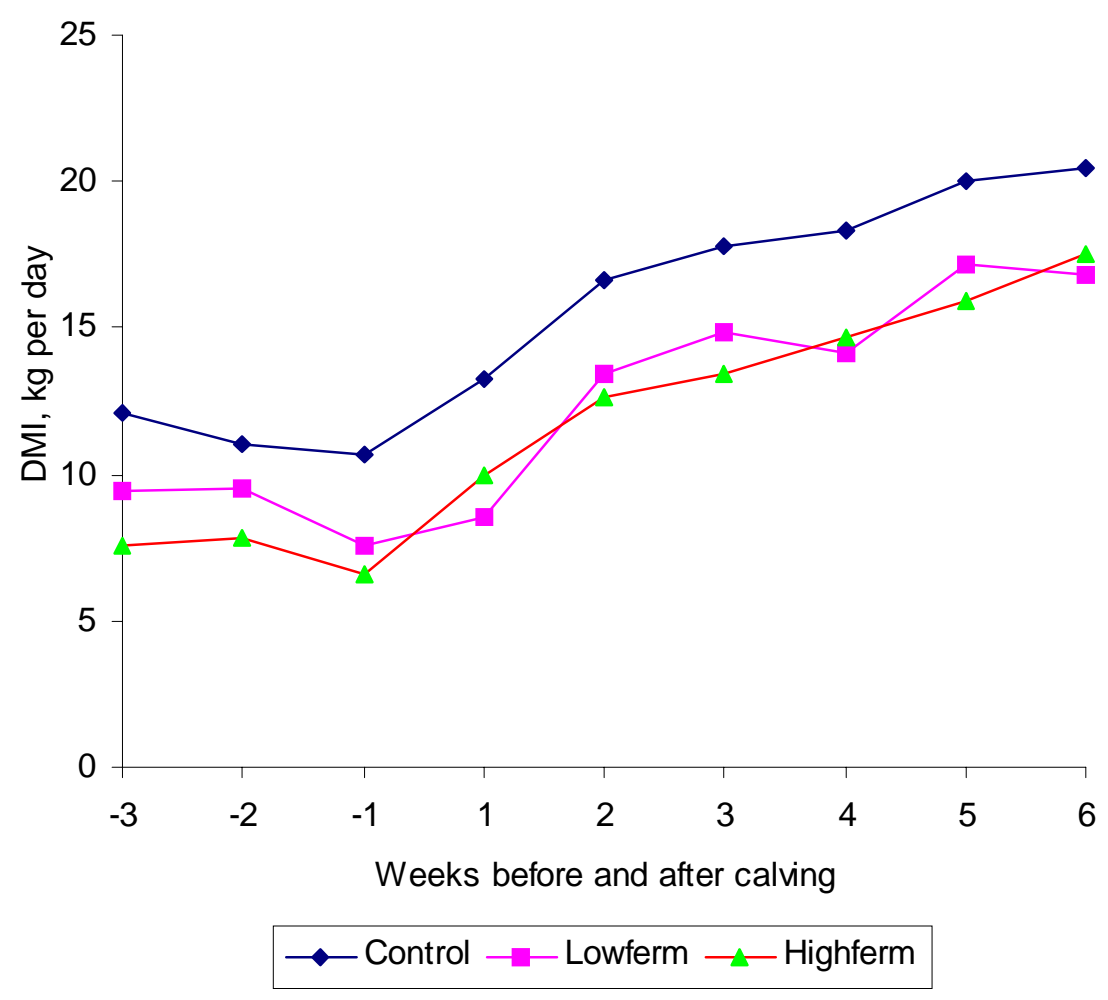

Figure 1. Dry matter intake, $\mathrm{kg} / \mathrm{d}$ before and after calving for all diets 
Marked differences in protein intake among the control and treatments, as well as between the two Fermenten diets also occurred during the dry period, as shown in figure 2 . Note that protein intake approached $1.0 \mathrm{~kg} / \mathrm{d}$ for cows on the high Fermenten diet at week -1 .

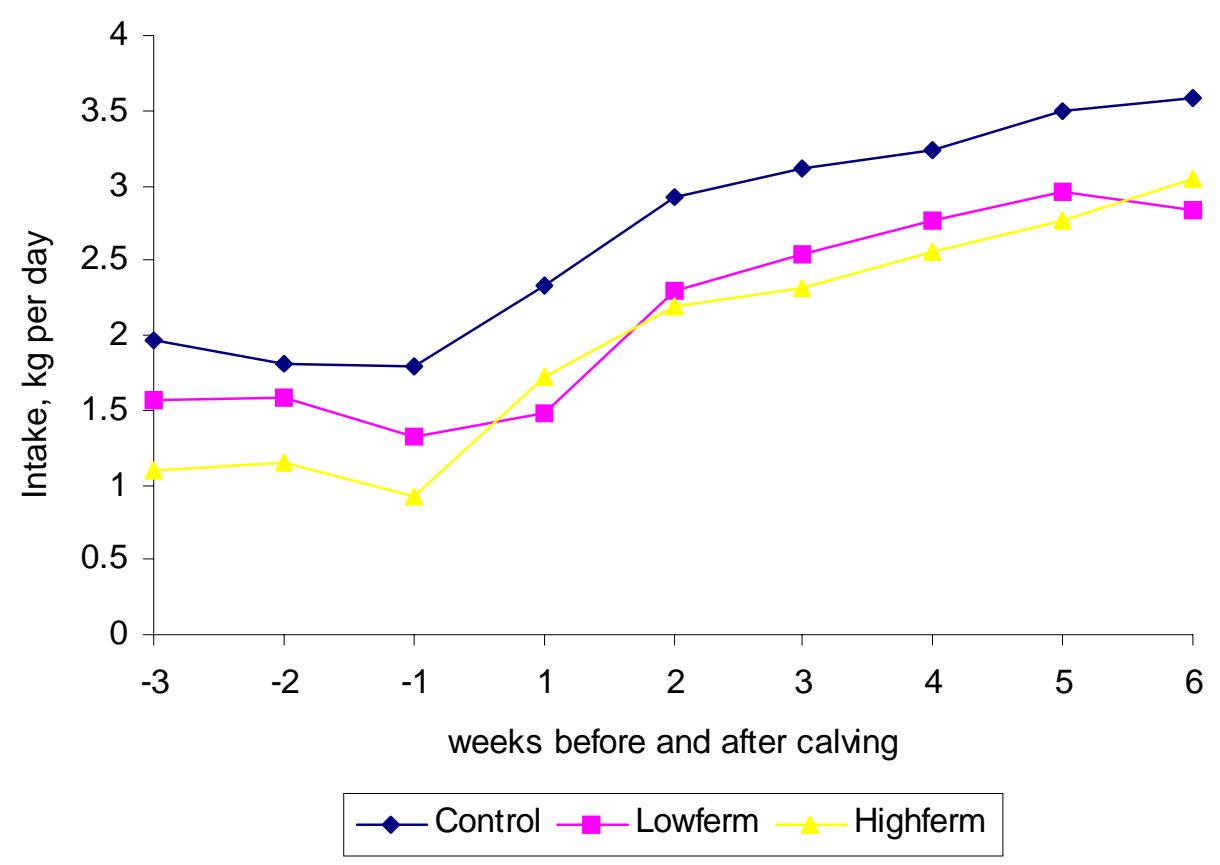

Figure 2. Crude protein intake, $\mathrm{kg} / \mathrm{d}$ before and after calving for all diets

Intakes after calving increased for all nutrients (Table 9). Intakes of DM, CP and NDF for the Fermenten treatments were significantly $(\mathrm{P}<0.05)$ lower than the control for only one wk post-calving. For weeks two through six, Fermenten diet intakes for most nutrients were only marginally lower that for the control diet $(\mathrm{P}<0.10)$.

Intake of NDF, expressed as percentages of body weight, is shown in Table 10. 
TABLE 9. Least square means for intake of dry matter (DM), crude protein (CP) neutral detergent fiber (NDF) and nonstructural carbohydrate (NSC) for the lactation period.

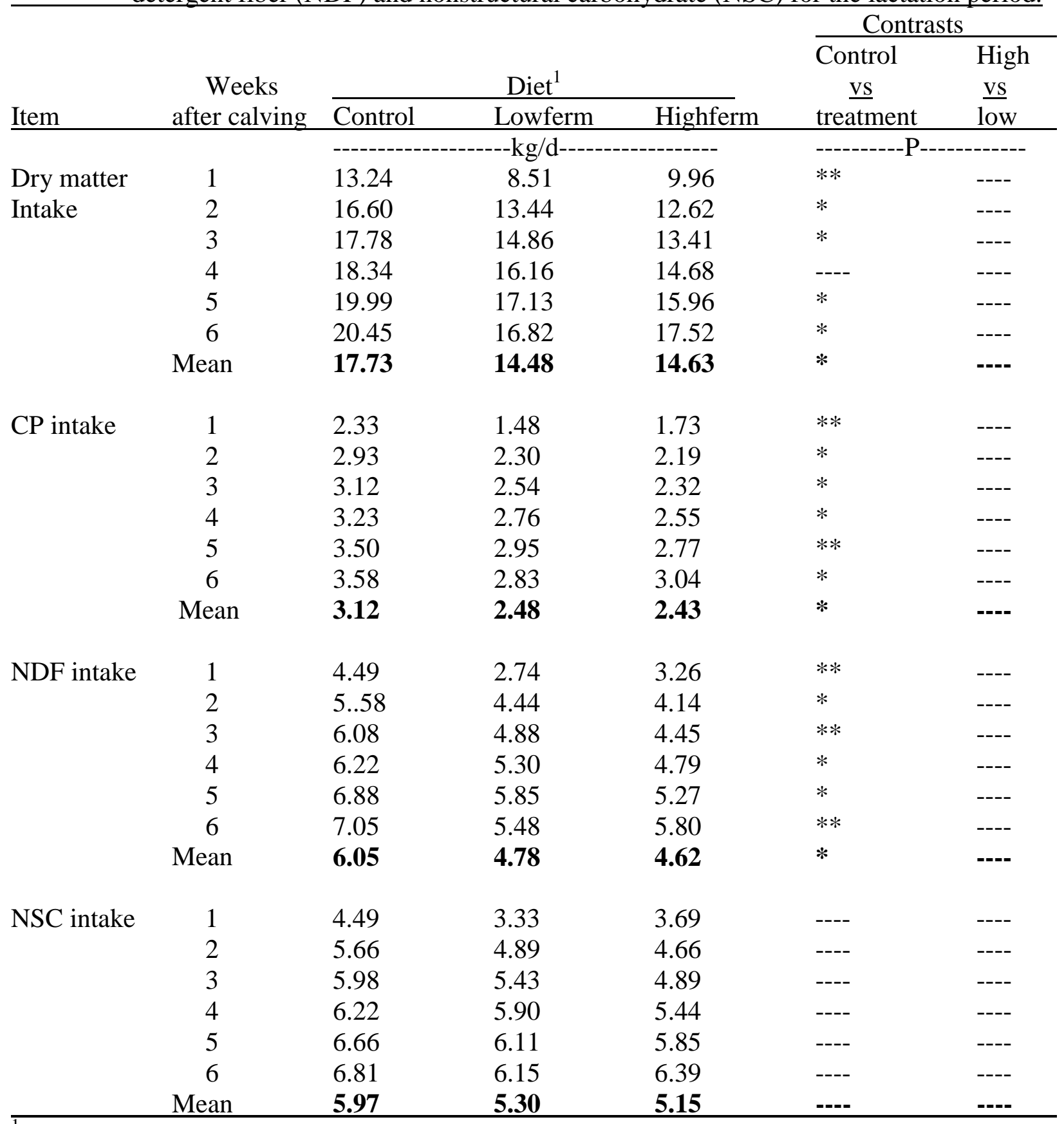

${ }^{1}$ Diets: control $=$ no Fermenten, Lowferm $=0.73 \mathrm{~kg}$ Fermenten DM $/ \mathrm{d}$, Highferm $=1,45 \mathrm{~kg}$ Fermenten DM/d

$* * * \mathrm{P}<0.01$
$* * \mathrm{P}<0.05$
$* \mathrm{P}<0.10$ 
$\underline{\text { TABLE 10. Intake of neutral detergent fiber as percentages of body weight }{ }^{1}}$

\begin{tabular}{|c|c|c|c|c|c|}
\hline \multirow{3}{*}{$\begin{array}{l}\text { Weeks relative } \\
\text { to calving }\end{array}$} & \multirow{2}{*}{\multicolumn{3}{|c|}{ Diets $^{2}$}} & \multicolumn{2}{|c|}{ Contrasts } \\
\hline & & & & control vs & high vs \\
\hline & Control & Lowferm & Highferm & treatment & low \\
\hline & & & & -----------H & -------- \\
\hline-3 & 0.84 & 0.69 & 0.60 & $* *$ & --- \\
\hline 0 & 0.74 & 0.59 & 0.57 & ** & --- \\
\hline 1 & 0.71 & 0.50 & 0.57 & --- & --- \\
\hline 2 & 0.93 & 0.80 & 0.85 & --- & --- \\
\hline 4 & 1.06 & 1.01 & 0.91 & --- & --- \\
\hline 6 & 1.15 & 1.02 & 1.05 & --- & -- \\
\hline
\end{tabular}

${ }^{1}$ Least square means

${ }^{2}$ Diets: Control $=$ no Fermenten, Lowferm $=0.73 \mathrm{~kg}$ Fermenten DM $/ \mathrm{d}$ Highferm $=1.45 \mathrm{~kg}$ Fermenten DM/d $* * \mathrm{P}<0.05$

Even for the control diet, NDF intake remained below $1 \%$ of body weight until week 4 of lactation, which is lower than most reported data.

Intakes of OM, ADF, starch, sugar and fat reflected dry matter intakes, and are in Tables 1 and 2 of the appendix.

Yield of milk, 4\% fat corrected milk (FCM) and percentages of fat and protein in the milk are presented in Table 11. In contrast to DM intake, both levels of Fermenten also significantly depressed milk yield during four of the six weeks of lactation. The mean depressions when compared to the were 6.50 and $5.95 \mathrm{Kg} / \mathrm{d}$ for the low and high Fermenten levels, respectively. The Kg milk produced per Kg DMI for both milk yield and FCM yield were similar for all diets, indicating that the efficiency of conversion of available nutrients to milk was not affected by Fermenten level. A difference in efficiency between Fermenten diets could have been compensated for by a greater mobilization of body tissue by cows on the poorer diet. This apparently did not happen, as indicated by the losses of body weight and body condition score as shown in Table 12. The average weight loss for the Fermenten 
treatments, while significantly greater than for the control cows, did not differ due to Fermenten level, indicating

TABLE 11. Least square means for lactation performance measures.

\begin{tabular}{|c|c|c|c|c|c|c|}
\hline & \multirow[b]{3}{*}{ Week } & \multirow{2}{*}{\multicolumn{3}{|c|}{ Diet $^{1}$}} & \multicolumn{2}{|c|}{ Contrasts } \\
\hline & & & & & \multirow{2}{*}{$\begin{array}{l}\text { control vs } \\
\text { treatment }\end{array}$} & \multirow{2}{*}{$\begin{array}{l}\text { High vs } \\
\text { low }\end{array}$} \\
\hline Item & & Control & Lowferm & Highferm & & \\
\hline & & & & & ----------P & \\
\hline \multirow[t]{7}{*}{ Milk yield, kg/d } & 1 & 21.24 & 15.34 & 17.41 & ---- & --- \\
\hline & 2 & 31.75 & 23.89 & 24.73 & $* *$ & --- \\
\hline & 3 & 33.46 & 26.83 & 26.09 & $* *$ & --- \\
\hline & 4 & 32.99 & 28.16 & 27.34 & $*$ & --- \\
\hline & 5 & 34.57 & 28.54 & 28.74 & $* *$ & --- \\
\hline & 6 & 34.73 & 27.02 & 28.80 & $* *$ & --- \\
\hline & Mean & 31.46 & 24.96 & 25.51 & $* *$ & --- \\
\hline \multicolumn{3}{|c|}{ Efficiency, $\mathrm{kg}$ milk/kg feed 1.77} & 1.72 & 1.82 & --- & --- \\
\hline \multirow{7}{*}{$\begin{array}{l}\text { 4\%Fat-corrected } \\
\text { milk, kg/d }\end{array}$} & 1 & 28.35 & 10.62 & 15.05 & $*$ & --- \\
\hline & 2 & 31.91 & 24.99 & 24.73 & $*$ & --- \\
\hline & 3 & 33.96 & 27.07 & 25.36 & $* *$ & --- \\
\hline & 4 & 31.09 & 27.14 & 24.66 & $*$ & --- \\
\hline & 5 & 34.00 & 27.13 & 27.51 & $* *$ & --- \\
\hline & 6 & 31.62 & 34.36 & 26.56 & $* *$ & --- \\
\hline & Mean & 31.09 & 24.69 & 25.31 & $* *$ & --- \\
\hline \multicolumn{3}{|c|}{ Efficiency, kg milk/kg feed 1.75} & 1.71 & 1.80 & -- & --- \\
\hline \multirow[t]{7}{*}{ Milk fat, \% } & 1 & 4.56 & 4.21 & 5.26 & --- & $* *$ \\
\hline & 2 & 4.10 & 4.38 & 4.01 & --- & --- \\
\hline & 3 & 4.14 & 4.18 & 3.86 & --- & --- \\
\hline & 4 & 3.65 & 3.73 & 3.41 & --- & --- \\
\hline & 5 & 3.96 & 3.71 & 3.68 & --- & --- \\
\hline & 6 & 3.38 & 3.34 & 3.50 & --- & --- \\
\hline & Mean & 3.97 & 3.93 & 3.95 & --- & --- \\
\hline \multirow[t]{7}{*}{ Milk protein, \% } & 1 & 3.97 & 3.97 & 4.25 & --- & --- \\
\hline & 2 & 3.28 & 3.33 & 3.40 & --- & --- \\
\hline & 3 & 3.08 & 3.19 & 3.19 & --- & --- \\
\hline & 4 & 2.91 & 3.12 & 3.01 & --- & --- \\
\hline & 5 & 2.90 & 3.09 & 2.91 & --- & --- \\
\hline & 6 & 2.94 & 3.13 & 3.00 & --- & --- \\
\hline & Mean & 3.18 & 3.30 & 3.29 & --- & --- \\
\hline
\end{tabular}

${ }^{1}$ Diets: Control $=$ no Fermenten, Lowferm $=0.73 \mathrm{~kg}$ Fermenten DM $/ \mathrm{d}$ Highferm $=1.45 \mathrm{~kg}$ Fermenten DM/d

$* * \mathrm{P}<0.05$

$* \mathrm{P}<0.1$ 
TABLE 12. Effect of treatments on body weight and body condition score ${ }^{1}$

\begin{tabular}{ccccccc}
\hline & & \multicolumn{3}{c}{} & & \multicolumn{2}{c}{ Contrasts } \\
\cline { 3 - 5 } Item & Week & Control & Lowferm & Highferm & $\begin{array}{c}\text { Control vs } \\
\text { Treatment }\end{array}$ & $\begin{array}{c}\text { Low vs } \\
\text { High }\end{array}$ \\
\hline \multirow{2}{*}{ Body weight, } & -3 & 654 & 609 & 601 & -------- P---------- \\
Kg & 0 & 634 & 550 & 558 & $* *$ & --- \\
& 2 & 621 & 559 & 556 & $*$ & --- \\
& 4 & 617 & 543 & 548 & $*$ & --- \\
& 6 & 612 & 544 & 548 & $*$ & --- \\
& Mean & 628 & 561 & 562 & $*$ & -- \\
Body & -3 & 3.78 & 3.54 & 3.69 & --- & --- \\
Condition & 0 & 3.50 & 2.96 & 3.25 & $* *$ & $*$ \\
Score & 2 & 3.32 & 3.04 & 3.15 & $*$ & --- \\
& 4 & 3.34 & 2.93 & 3.01 & $* * *$ & --- \\
& 6 & 3.23 & 2.99 & 2.98 & -- & --- \\
\hline
\end{tabular}

${ }^{1}$ Least square means

${ }^{2}$ Diets: control $=$ no Fermenten, Lowferm $=0.73 \mathrm{~kg}$ Fermenten DM $/ \mathrm{d}$, Highferm $=1.45 \mathrm{~kg}$ Fermenten DM/d

$* * * \mathrm{P}<0.01$

** $\mathrm{P}<0.05$

* $\mathrm{P}<0.1$

similar amounts of tissue nutrients were available to both treatment groups. Body condition scores show losses before calving for all groups. Between 3 weeks prior to calving and parturition, BCS losses were $-0.25,-0.58$ and -0.44 for the control, low Fermenten and high Fermenten groups. These values reflect the decreases in intake found for all groups prior to calving. Unlike other measurements, such as DM intake, milk production and weight loss, where both Fermenten levels caused similar responses, BCS loss was somewhat less for the cows fed the high Fermenten. This difference approached significance $(\mathrm{P}<0.10)$ in the week of parturition, and was numerically evident for most of the experimental period, as seen in Figure 3. 


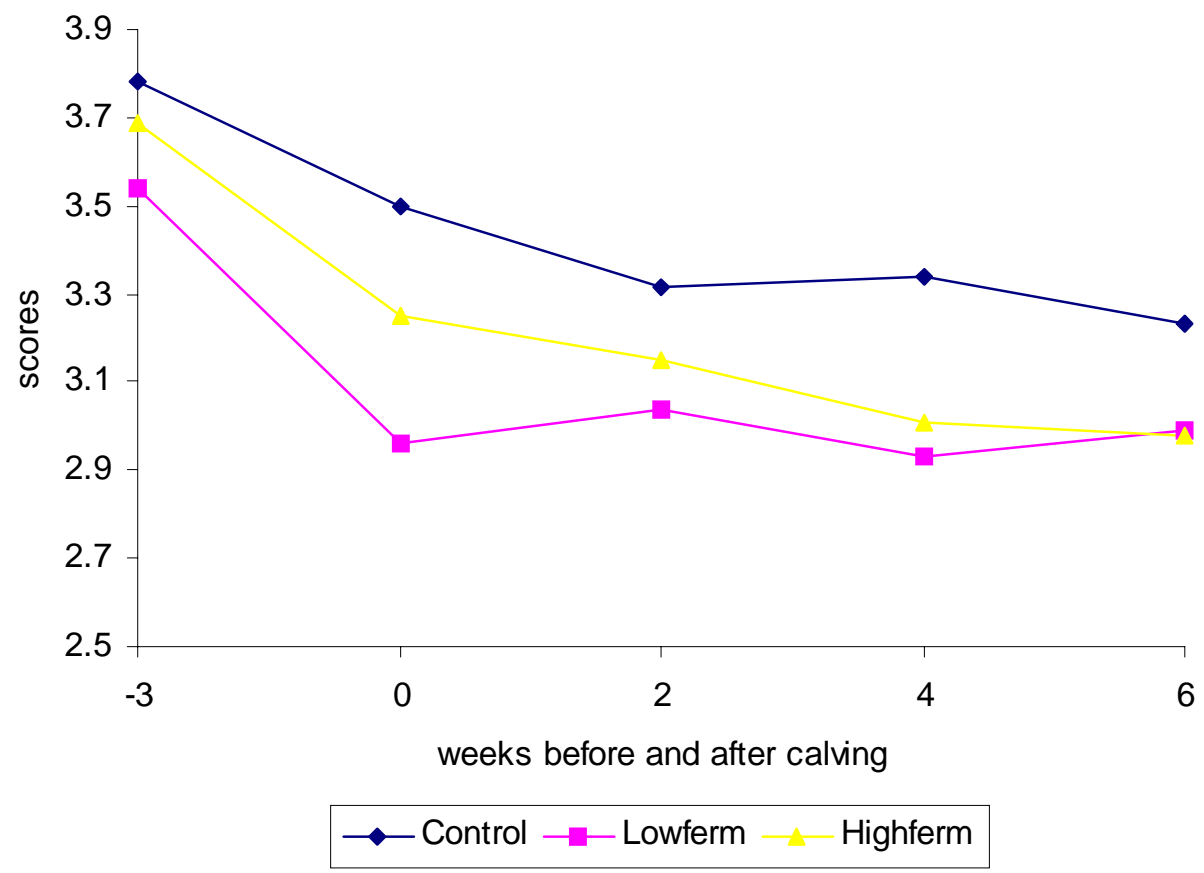

Figure 3. Body condition score before and after calving

While efficiency of use of nutrients for production of milk, especially FCM, reflect energy utilization, protein utilization is more closely associated with losses of $\mathrm{N}$ in urine and milk. Table 13 gives the values for milk urea nitrogen levels for all diets. No differences were noted in $\mathrm{N}$ utilization, indicating that the $\mathrm{N}$ components in Fermenten were utilized as efficiently as those of the soybean meal it replaced. 
TABLE 13. Effect of treatments on milk urea nitrogen (MUN) ${ }^{1}$

\begin{tabular}{|c|c|c|c|c|c|}
\hline \multirow[b]{3}{*}{ Week } & \multirow{2}{*}{\multicolumn{3}{|c|}{$\operatorname{Diet}^{2}$}} & \multicolumn{2}{|c|}{ Contrasts } \\
\hline & & & & \multirow{2}{*}{$\begin{array}{l}\text { control vs } \\
\text { treatment }\end{array}$} & \multirow{2}{*}{$\begin{array}{l}\text { high vs } \\
\text { low }\end{array}$} \\
\hline & Control & Lowferm & Highferm & & \\
\hline & & $-\mathrm{mg} / \mathrm{dl}----$ & & ----------P-- & --- \\
\hline 1 & 11.00 & 12.50 & 9.25 & --- & $* *$ \\
\hline 2 & 12.91 & 12.84 & 11.28 & --- & --- \\
\hline 3 & 13.94 & 14.01 & 13.94 & --- & --- \\
\hline 4 & 15.17 & 14.83 & 15.33 & --- & --- \\
\hline 5 & 15.73 & 17.02 & 15.40 & --- & --- \\
\hline 6 & 15.35 & 16.06 & 16.02 & --- & --- \\
\hline
\end{tabular}

${ }^{1}$ Least square means

${ }^{2}$ Diets: Control $=$ no Fermenten, Lowferm $=0.73 \mathrm{~kg}$ Fermenten DM $/ \mathrm{d}$, Highferm $=1.45 \mathrm{~kg}$ Fermenten DM/d

$* * \mathrm{P}<0.05$

Milk fat and protein percentages are shown Table 11. Milk fat did not differ due to treatments and averaged 3.97, 3.93 and 3.95 for cows fed the control, low Fermenten and high Fermenten diets, respectively. Milk protein percentages were similar across all diets, however, the mean values for cows fed the Fermenten treatments were numerically higher than for the control cows. Average protein percentages for cows on the control, low Fermenten and high Fermenten diets were 3.18, 3.30 and 3.29, respectively.

Fat and protein yields, in $\mathrm{kg} / \mathrm{d}$, are shown in figures 4 and 5, respectively.

Fat yield remained approximately $.3 \mathrm{~kg} / \mathrm{d}$ less for the Fermenten treatments than for the control throughout the lactation period. Because of the increase in milk protein percentage, protein yield increased rapidly by week 2 and approached that of cows on the control diet, despite the significantly lower milk production on the Fermenten treatments. 


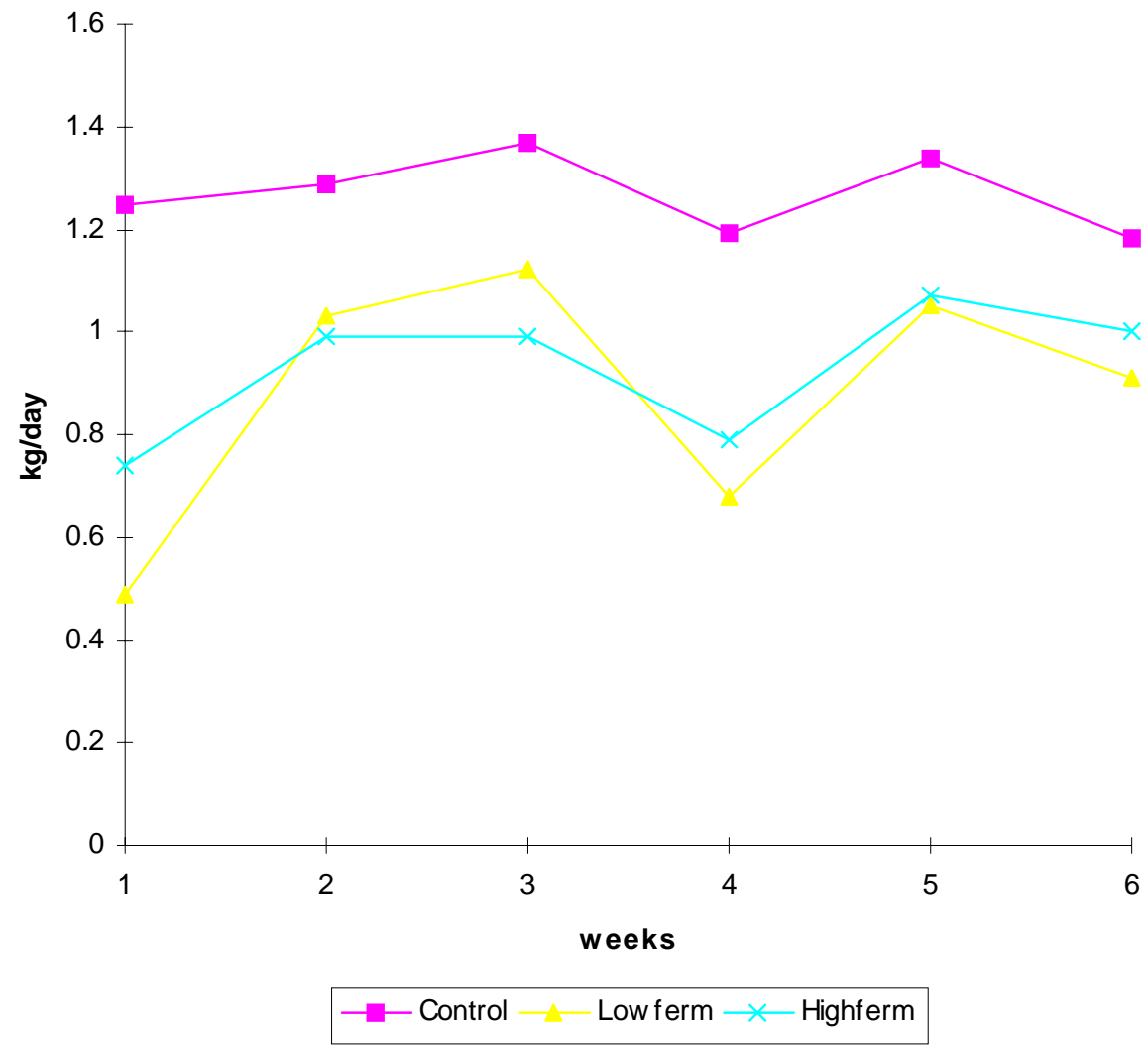

Figure 4. Fat yield $(\mathrm{kg} / \mathrm{d})$ for cows on each diet 


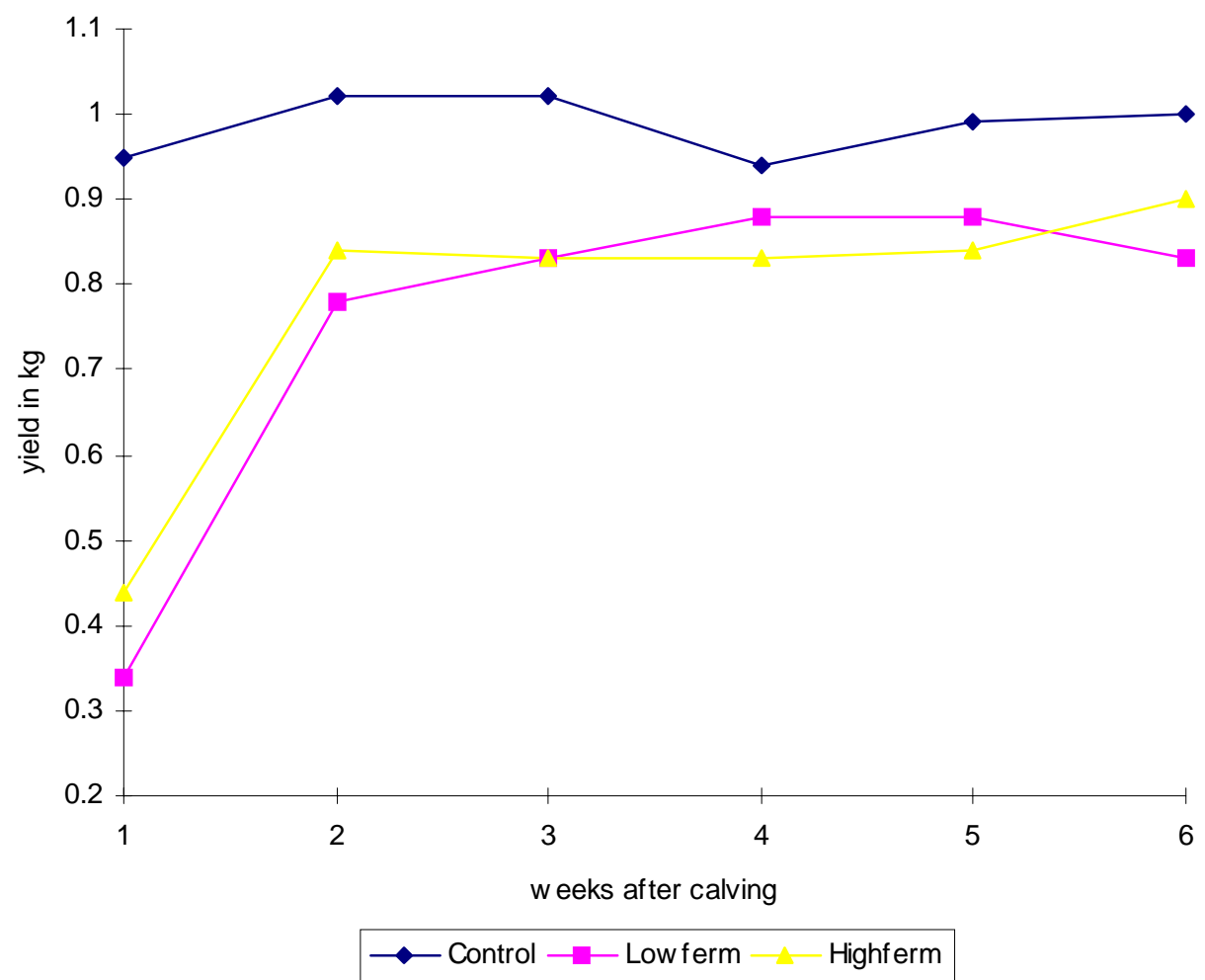

Figure 5. Protein yields during 6 weeks of lactation. 
Total disease episodes recorded during this study are summarized in Table 14.

TABLE 14. Effect of treatments on metabolic disorders ${ }^{1}$

\begin{tabular}{llll}
\hline Cow \# & Diet & Disorders & Total Cows $^{2}$ \\
\hline $847 \mathrm{~A}$ & DC/LC & Mastitis & \\
943 & ، & Laminitis &
\end{tabular}

990

DA/LA ${ }^{4} \quad$ Displaced abomasum

Retained placenta

898

“ Displaced abomasum

Retained placenta

Mastitis

$858 \mathrm{~A}$

“

Displaced abomasum

Retained placenta

853

941

101

$824 \mathrm{~A}$

$\mathrm{DB} / \mathrm{LB}^{5}$
$\cdots$
$،$
$،$

Retained placenta

Retained placenta

Retained placenta

Displaced abomasum

Retained placenta

${ }^{1}$ Total cows with disorders, by diet

$\mathrm{DC} / \mathrm{LC}=2$

$\mathrm{DA} / \mathrm{LA}=7$

$\mathrm{BD} / \mathrm{LB}=5$

${ }^{2}$ Total number of animals on diet

${ }^{3} \mathrm{DC} / \mathrm{LC}=$ Control

${ }^{4} \mathrm{DA} / \mathrm{LA}=$ Fermenten $0.73 \mathrm{~kg} / \mathrm{d} \mathrm{DM}$

${ }^{5} \mathrm{DB} / \mathrm{LB}=$ Fermenten $1.45 \mathrm{~kg} / \mathrm{d} \mathrm{DM}$

The summary of disorders were control cows 2, low Fermenten 7 and high Fermenten 5. Because of the unexpectedly high prevalence of disorders, the study was terminated prior to completion of the proposed 10 cows/group. There were a total of 23 cows that completed the treatments, of which 9 cows had disorders for a total of 14 disorders. The diseases observed were laminitis, displaced abomasum, retained placenta, and mastitis. The percentage of cows on the control diet that had problems was 29\%; the low Fermenten diet $38 \%$ and the high Fermenten 
diet 50\%. Although cows on the treatment diets had more incidences than those on the control diet, this was not significant $(\mathrm{P}>0.1)$ based on Chi-square analysis.

In considering the likelihood of a relationship between the treatments and the various disorders observed, it is probable that the mastitis was not associated with the diets. Table 15 shows the somatic cell counts in the milk from cows on all treatments. Somatic cell numbers indicate subclinical mastitis. Since the count includes sloughed-off mammary gland cells, the counts in the week immediately post-calving are normally higher than subsequent weeks. Values $<200,000$ are considered to indicate little to no infection. The lack of differences between the control cows and treatment cows make it highly unlikely that the mastitis

TABLE 15. Effect of Fermenten on somatic cell count ${ }^{1}$

\begin{tabular}{|c|c|c|c|c|c|}
\hline \multirow[b]{3}{*}{ Week } & \multirow{2}{*}{\multicolumn{3}{|c|}{ Diet $^{2}$}} & \multicolumn{2}{|c|}{ Contrasts } \\
\hline & & & & \multirow{2}{*}{$\begin{array}{l}\text { control vs } \\
\text { treatment }\end{array}$} & \multirow{2}{*}{$\begin{array}{l}\text { high vs } \\
\text { low }\end{array}$} \\
\hline & Control & Lowferm & Highferm & & \\
\hline & \multicolumn{3}{|c|}{----------------1000/ml---------------------- } & \multicolumn{2}{|c|}{----------P--------- } \\
\hline 1 & 382 & 580 & 487 & --- & --- \\
\hline 2 & 223 & 66 & 110 & --- & --- \\
\hline 3 & 98 & 128 & 47 & --- & --- \\
\hline 4 & 26 & 278 & 40 & --- & --- \\
\hline 5 & 37 & 142 & 22 & --- & --- \\
\hline 6 & 18 & 621 & 27 & --- & --- \\
\hline
\end{tabular}

${ }^{1}$ Least square means

${ }^{2}$ Diets: control $=$ no Fermenten Lowferm $=0.73 \mathrm{~kg}$ Fermenten DM $/ \mathrm{d}$ Highferm $=1.45 \mathrm{~kg}$ Fermenten DM/d

cases were diet-related. Laminitis is the result of lactic acidosis, usually brought on by overfeeding a high-grain diet. Since 2 to 3 months are required between the dietary insult and the manifestation of the disease, it is unlikely that the laminitis was caused by the experimental diet. If, therefore, only the periparturient metabolic disorders are considered (displaced abomasum and retained placenta) the cows involved/group were: control 0\%, low Fermenten $38 \%$ and high Fermenten 50\%. This observation led to termination of the study without regard to the statistical significance. 
During the final weeks of the project, the Fermenten was locally analyzed (Skyview labs, Jennerstown, PA) for minerals, with the findings of $1.99 \% \mathrm{~S}$, a value less than used in the initial ration formulations. Chloride analysis was not performed. Subsequently, a sample of Fermenten was returned to the manufacturer, and was found to contain $0.36 \% \mathrm{Cl}$ and $5.40 \% \mathrm{~S}$. This raised the $\mathrm{S}$ contents of diet DA and DB to $0.56 \%$ and $0.90 \%$, respectively. When these values were used to calculate the DCAD, the new estimates were, for the dry cow control, low Fermenten and high Fermenten were $+24.3,+2.1$ and -20.1 respectively. Urine $\mathrm{pH}$ values then were determined on the cows remaining on the study. The $\mathrm{pH}$ values are reported in Table 16. Although the number of measurements were few, it appears that both Fermenten treatments reduced urine $\mathrm{pH}$ in both the dry and lactation periods, thus the acidification properties of Fermenten were much higher than expected when the study was designed.

TABLE 16. Urine $\mathrm{pH}$ values

\begin{tabular}{llc}
\hline Diet $^{1}$ & $\mathrm{pH}^{2}$ & Samples $^{3}$ \\
\hline DC & 7.67 & 14 \\
DA & 5.70 & 7 \\
DB & 6.40 & 1 \\
LC & 7.70 & 5 \\
LA & 6.19 & 6 \\
LB & 6.00 & 10 \\
\hline
\end{tabular}

${ }^{1}$ Diets: $\mathrm{DC}=$ Control, $\mathrm{DA}=0.73 \mathrm{~kg}$ Fermenten DM/d

$\mathrm{DB}=1.45 \mathrm{~kg}$ Fermenten DM $/ \mathrm{d}, \mathrm{LC}=$ Lactation Control

$\mathrm{LA}=$ Lactation $0.73 \mathrm{~kg}$ Fermenten DM/d,

${ }^{2}$ Mean values

$\mathrm{LB}=$ Lactation $1.45 \mathrm{~kg}$ Fermenten DM/d

${ }^{3}$ Number of samples in mean

The $\mathrm{S}$ contents found for the lactation rations were $0.22,0.39$ and $0.58 \%$ for LC, LA and $\mathrm{LB}$, respectively. The higher $\mathrm{S}$ levels in rations LA and LB reduced the DCAD values to 15.1 and 5.5, respectively; values considerably lower than originally formulated in Table 4. This explains the low urine $\mathrm{pH}$ values for lactating cows in Table 16. 


\section{CHAPTER 5. DISCUSSION}

The beginning weights of the cows in this study ranged from 601 to $654 \mathrm{~kg}$, (Table 12). Eastridge et al., (1998) recently summarized predicted intakes of dry cows from five ration balancing programs in current use, which were developed by the NRC, Ohio State, Cornell-Penn, Michigan State and the DART ration program. For dry cows weighing $660 \mathrm{~kg}$, and within 21 days of calving, predicted intakes ranged from 9.4 to $11.5 \mathrm{~kg}$. The average intake of the control cows in this study was $11.3 \mathrm{~kg} / \mathrm{d}$, which is at the high end of the predictions. This indicates the control ration was consumed at expected levels and was of normal palatability. It has been reported that cows consuming rations, such as the control diet in this study, will experience a decrease in DMI of up to 30\% during the final $7 \mathrm{~d}$ prepartum (Bertics et al., 1992). The control cows in this study decreased intake by $12 \%$ over the entire $3 \mathrm{wk}$ period prior to calving, but only 3.6\% during the last $7 \mathrm{~d}$ (Table 7). Intakes of the Fermenten diets were severely depressed at the initiation of the study, and declined an additional 16-20\% during the last 7 days prepartum (Tables 6 and 7). The marked depressions in intake of the Fermenten diets were not anticipated, since in a previous study with an anionic by-product, BioChlor, which contained $8.9 \% \mathrm{Cl}$ and 2.7\% S (DM basis), intake of the BioChlor fed cows was higher than that of the controls throughout the dry cow feeding period of 5 wks (Hoover et al., 1998). Due to high $\mathrm{Cl}$ and $\mathrm{S}$ levels, the BioChlor-containing diet had a DCAD of -9.4 meq/100g, which was much more negative than initially estimated for the Fermenten diets in the current study, both of which had positive DCAD values (Table 4). After it was determined that the Fermenten sulfur content was 5.4\% rather than $2.4 \%$, the DCAD values of the Fermenten diets for dry cows were recalculated and found to be +2.1 and -20.1 for the Lowferm and Highferm diets, respectively. Even taking the new DCAD values into account, the average intake depressions of 2.45 and $4.04 \mathrm{~kg} / \mathrm{d}$ for the 
Lowferm and Highferm diets, respectively, were greater than reported in other studies of anionic diets. Vagnoni and Oetzel (1998) and Lema et al., (1992) reported depressions of 0.6 to $1.6 \mathrm{~kg}$ $\mathrm{DM} / \mathrm{d}$ due to anionic diets. Oetzel and Barmore (1993) reported depressions of 0.53 to $1.7 \mathrm{~kg}$ $\mathrm{DM} / \mathrm{d}$ in an extensive comparison of the palatability of several anionic salts, with $\mathrm{CaCl}_{2}$ causing the greatest depression and $\mathrm{MgSO}_{4}$, the anion source in Fermenten, causing an intake depression of $1.5 \mathrm{~kg} / \mathrm{d}$. The much greater intake depressions caused by Fermenten in our study suggest the possibility that components in addition to sulfur negatively affected palatability.

Actual nutrient intakes for the dry cows during the final week before parturition are compared to the nutrient intakes recommended by the Spartan Ration Balancing Program in Table 17. This is a critical time in terms of protein, energy, carbohydrate and mineral intake. When evaluated in terms of traditional nutrient requirements, the control cows received adequate total protein, $\mathrm{NE}_{\mathrm{L}}$, UIP and DIP.

TABLE 17. Nutrient intakes and recommendations during the week prior to parturition.

\begin{tabular}{lcccc} 
Item & Required $^{1}$ & Control & Lowferm & Highferm \\
\hline $\mathrm{CP}, \mathrm{kg} / \mathrm{d}$ & 1.6 & 1.8 & 1.3 & .90 \\
$\mathrm{UIP}, \mathrm{kg} / \mathrm{d}$ & .5 & .8 & .5 & .2 \\
$\mathrm{DIP}, \mathrm{kg} / \mathrm{d}$ & .9 & 1.0 & .8 & .7 \\
$\mathrm{NE}$, Mcal/d & 16.0 & 17.0 & 11.8 & 10.1 \\
$\mathrm{NDF}, \mathrm{kg} / \mathrm{d}$ & 3.5 & 4.6 & 3.2 & 3.2 \\
$\mathrm{NSC}, \mathrm{kg} / \mathrm{d}$ & 3.8 & 3.2 & 2.4 & 1.7 \\
$\mathrm{Ca}, \mathrm{g} / \mathrm{d}$ & 39 & 51 & 33 & 27 \\
$\mathrm{P}, \mathrm{g} / \mathrm{d}$ & 24 & 32 & 26 & 26 \\
$\mathrm{Cl}, \mathrm{g} / \mathrm{d}$ & 20 & 29 & 22 & 20 \\
$\mathrm{~S}, \mathrm{~g} / \mathrm{d}$ & 16 & 23 & 43 & 60
\end{tabular}

${ }^{1}$ From Spartan Ration Balancing Program

Calcium and $\mathrm{P}$ were higher than recommended, although no mineral sources were added to the diet. Goings et al. (1974) reported that $51 \mathrm{~g} \mathrm{Ca} / \mathrm{d}$ prepartum caused a higher incidence of milk fever than did a diet with $8 \mathrm{~g} \mathrm{Ca}$. Although there were no problems with metabolic 
disorders at parturition in the control group in the current study, this does point out the difficulty of providing a low $\mathrm{Ca}$ diet under most feeding situations.

Due to the calorie-protein deficiencies in the cows fed Fermenten, the loss of weight and body condition were 2-3 times greater than for the control cows at parturition (Table 12). In addition, Ca intakes on the Fermenten diets were less than recommended by NRC (1989), and far below the recommended Ca intake of 120-150 g/d for cows fed anionic diets (Goff and Horst, 1996). Although not measured in this study, Hoover et al. (1998) reported urinary Ca excretion of dry cows increased 5 to 6 fold within 6 to $8 \mathrm{~d}$ of being placed on an anionic diet. The large $\mathrm{Ca}$ losses require a high $\mathrm{Ca}$ diet during this period, which is the reason for the $\mathrm{Ca}$ recommendation.

In terms of development of the rumen and increasing microbial growth pre-calving, all diets appear to be deficient. The major nutrients needed are DIP and NSC. The Spartan recommendation of $0.9 \mathrm{Kg}$ DIP for these cows appears to be in error and should be $1.1 \mathrm{~kg} / \mathrm{d}$, so that the UIP and DIP add up to 1.6. An intake of $1.1 \mathrm{~kg}$ DIP would bring the level to $10 \%$ of DMI as DIP, a quantity within the recommendations in Table 2. The recommendation for NSC of $3.8 \mathrm{~kg} / \mathrm{d}$, for cows consuming $10-11 \mathrm{Kg} \mathrm{DM} / \mathrm{d}$, would provide $36 \%$ of diet DM as NSC, a value also within the range in Table 2 for late dry cows. The control cows consumed an appropriate amount of DM $(10.7 \mathrm{~kg} / \mathrm{d})$ during the last week prior to calving, in spite of the control diet being higher in NDF and lower in NSC than expected. This was due to the hay being of poorer quality than initial analyses indicated. The level of NDF in all dry cow diets also exceeded the recommendations in Table 2, and while the high NDF may not have limited intake, it did result in the diets containing less NSC than needed for maximum microbial growth. Limited microbial growth would reduce the microbial protein supply as well as energy sources in 
the form of volatile fatty acids. The amount of UIP available was likely insufficient to compensate for the decreased microbial growth, resulting in severe protein deficiencies in the Fermenten fed cows, and possibly a slight deficiency in the control cows as well. These nutrient deficiencies, along with the $\mathrm{Ca}$ losses, resulted in the high incidence of metabolic disorders at calving.

After calving, although the expected DCAD balances all were positive as shown in Table 4, the actual $\mathrm{S}$ and $\mathrm{Cl}$ resulted in DCAD values for lactation rations $\mathrm{A}$ and $\mathrm{B}$ of 15.1 and 5.5, respectively. While still positive, these DCAD values are well below the $35-40$ meq/100g found to maximize intake and production in data summarized by Sanchez and Beede (1994). As a consequence of the unpalatable nature of the rations as well as the low DCAD values, DMI relative to that on the control diet was greatly reduced in wk 1 of lactation $(\mathrm{P}<0.05)$ and marginally reduced $(\mathrm{P}<0.10)$ for wks $2,3,5$ and 6 . While the reductions overall are not statistically significant, the numerical decrease, when averaged over the entire 6 wks, was 3.2 $\mathrm{Kg} / \mathrm{d}$ for the diets with Fermenten. Milk production reflected the depressed intake, and was significantly lower $(\mathrm{P}<0.05)$ for most of the $6-\mathrm{wk}$ lactation period. There were no major differences in intake or production between the Lowferm and Highferm diets, thus the difference in DCAD between 5.5 and 15.1 did not affect these values.

The mechanism of the marked depressions in intake caused by Fermenten is not clear. While it may be due to unidentified components in the product, it is more likely associated with some aspect of sulfur metabolism. This could be simply the unpalatable nature of $\left(\mathrm{NH}_{4}\right)_{2} \mathrm{SO}_{4}$, as shown in several studies. It also may be associated with a physiological response to an anionic or nearly anionic diet. A further explanation may be in the toxicity of sulfur to ruminants. Kandylis (1984) reviewed studies on sulfur toxicity, and recommended that diets containing 
greater than $4 \%$ sulfur could result in neural symptoms, labored breathing and depressed intake. Although neural symptoms were not noted in this study, the effects of toxicity may have been present at a subclinical level. The toxicity, according to work reviewed by Kandylis (1984) is probably the result of the ruminal reduction of $\mathrm{S}$ to hydrogen sulfide gas. Upon eructation, a portion of all rumen gasses enters the lungs via the trachea. When $\mathrm{H}_{2} \mathrm{~S}$ is present, severe toxic symptoms result.

The percentages of $\mathrm{S}$ in the DA, DB, LA and LB diets were 0.56, 0.90, 0.39 and 0.55 respectively, thus meeting or exceeding the recommended maximum of $.4 \%$ for all groups. In terms of $\mathrm{g} \mathrm{S} / \mathrm{d}$, a $0.4 \% \mathrm{~S}$ diet fed to a dry cow at $11 \mathrm{~kg} \mathrm{DM} / \mathrm{d}$ and a lactating cow at $20 \mathrm{~kg} \mathrm{DM} / \mathrm{d}$ would result in intakes of 44 and $80 \mathrm{~g}$, respectively. Average daily intakes of $\mathrm{S}$ in this study, based on actual DM intake and S content were: DC, 25g; DA, 50g; DB, 66g; LC, 39g; LA, 56g; $\mathrm{LB}, 80 \mathrm{~g}$. Only diet DB, with an estimated intake of $66 \mathrm{~g} / \mathrm{d}$, exceeded the maximum thought to represent the threshold of toxicity. All other groups apparently stopped eating before this level was reached. It appears that $\mathrm{S}$ levels in the diets may have regulated intake, although the mechanism is not clear. Sulfur in the form of sulfate has been used to regulate intake of feed supplements in the past (Kandylis, 1984), and may have been instrumental in reducing intake in this study. 


\section{CHAPTER 6. SUMMARY AND CONCLUSIONS}

Fermenten (Biovance Technologies Inc., Omaha NE) is sold as an amendment to rations of growing heifers and lactating cows, where it ostensibly improves growth and production through effects on protein metabolism. Fermenten has not been used in the rations of dry cows. This study was designed to determine the effects of feeding three levels of Fermenten; 0, 0.73 and $1.45 \mathrm{~kg} \mathrm{DM} / \mathrm{d}$, to cows in the late dry period and continuing through $6 \mathrm{wk}$ of lactation. Measures included intake, production, body weight changes and incidence of periparturient metabolic disorders.

Although the DM intake of all cows was decreased as parturition approached the feeding of Fermenten at either 0.73 or $1.45 \mathrm{~kg} \mathrm{DM} / \mathrm{d}$ markedly reduced DM intake compared to that of the control cows, with no significant difference in intake depression between Fermenten levels. Intake of protein and NSC were, however, significantly lower for the cows fed the high level of Fermenten compared to cows fed the low level. Fermenten was found to have an anionic dietary cation-anion balance, which resulted in systemic acidification as indicated by low urine $\mathrm{pH}$. The combination of low nutrient intake and systemic acidification caused a higher incidence of periparturient metabolic disorders in cows fed both levels of Fermenten compared to the control cows.

Following parturition, DM intakes of the Fermenten fed cows were only marginally lower than control cows $(\mathrm{P}<0.1)$, but remained numerically lower for the 6 wk lactation period. Milk production was significantly and equally reduced by the inclusion of both levels of Fermenten in the diets. Loss of body weight during the dry period was significantly greater for the cows fed Fermenten, but was not significantly different than the control cows following parturition. 
From the results of this study it can be concluded that:

1. Intake of DM of all cows decreased as the cows approached parturition.

2. Compared to control cows, cows fed Fermenten at either 0.73 or $1.45 \mathrm{~kg} \mathrm{DM} / \mathrm{d}$ had significantly greater depressions in DM intake and lost more body weight in the dry period.

3. Fermenten contained sufficient anionic salts to lower urine $\mathrm{pH}$.

4. Cows fed Fermenten had a higher incidence of periparturient disorder than did control cows.

5. After parturition, milk yield of cows on the Fermenten diets was reduced compared to control cows.

6. Fermenten is not recommended as an amendment to the rations of close-up dry cows. 


\section{LITERATURE CITED}

Baker, L. D. and J. D. Ferguson. 1994. Milk urea nitrogen as a metabolic indicator of protein feeding efficiency on dairy farms. Proc. annu. Conv. Am. Asso. Bovine pract. Stillwater, Okla. P 165-166.

Battaglia, F. C., and G. Meschia. 1978. Principal substrates of fetal metabolism. Physiological Reviews 58: 499

Batajoo, K. K and R. D. Shaver. 1994. Impact of Nonfiber Carbohydrate on intake, digestion and milk production by Dairy cows. J. Dairy Sci. 77: 1580-1588.

Bell, A. W. 1995. Regulation of Organic Nutrient Metabolism During Transition from Late Pregnancy to Early Lactation. J. Anim. Sci. 73: 2804-2819

Bertics, S. J., R. R. Grummer, C. Cadorniga-Valino, and E. E.Stoddard. 1992. Effect of prepartum dry matter intake on liver triglyceride concentration in early lactation. J. Dairy Sci. 75: 1994.

Block, E. 1984. Manipulating dietary anions and cations for prepartum dairy cows to reduce incidence of milk fever. J. Dairy Sci. 67: 2939-2948.

Broderick, G.A. and W. M. Craig. 1989. Metabolism of peptides and amino acids during in vitro protein degradation by mixed rumen organisms. J. Dairy Sci. 72: 25-2549

Bryant, M. P. 1974. Nutritional features and ecology of predominant anaerobic bacteria of the intestinal tract. Am. J. Clin. Nutr. 27:1313.

Chalupa, W., C. J Sniffen and W. H. Hoover. 1997. Adoption of Technology: The way to the future. Current Topics in Dairy Production, Vol. 2. Dairy Res. Foundation, Univ.of Sydney. Moama, NSW, Australia.

Chen, G. and J. B. Russell. 1989. More Monensin sensitive and ammonia producing bacteria from the rumen. Appl. Environ. Microbiol. 55: 1052-1061.

Clark, J.H. and C. L. Davis. 1978. Energy and protein needs of lactating Dairy Cows. Illinois Res. 20(3): 14.

Clark, J.H., T. H. Klusmeyer, and M.R. Cameron. 1992. SClark, J.H., T. H. Klusmeyer, and M.R. Cameron. 1992. Symposium: Nitrogen Metabolism and Amino Acid Nutrition in Dairy cattle. Microbial Protein Synthesis and flows of Nitrogen Fractions to the Duodenum of Dairy Cows. J. Dairy Sci. 75:2304-2323.

Coppock, C. E. 1974. Displaced abomasum in dairy cattle: Etiological factors. J. Dairy Sci. 56: 926. 
Cote, J. F. 1992. Health Management Practices for Dry Dairy Cows. Onterio Ministry of Agriculture, Food and Rural Affairs (OMAFRA) factsheet Agdex 414/20.

Curtis, C. R., H. N. Erb, C. J. Sniffen, R.D. Smith, and D. S. Kronfeld. 1985. Path analysis of dry period nutrition, postpartum metabolic and reproductive disorders, and mastitis in Holstein cows. J. Dairy Sci. 68: 2347.

Dijkstra, J. 1994. Production and absorption of volitel fatty acids in the rumen. Livest. Prod. Sci. 39:61.

Eastridge, M. L., H. F. Buckholtz, A.L. Slater and C.S. Hall. 1998. Nutrient requirements for dairy cattle of the National Research Council versus some commonly used ration software. J. Dairy Sci. 81: 3059-3062.

Eastridge, M. L., M. D. Cunningham and J. A. Peterson. 1988. Effect of dietary energy source and concentration on performance of dairy cows during early lactation. J. Dairy Sci. 71:2959.

Ender, F. and I.W. Dishington. 1970. Etiology and prevention of paresis puerperalis in dairy cows PP 71-79 in Parturient Hypocalcemia. JJB Anderson, ed. Academic Press, New York.

Faulkner, A. 1983. Foetal and neonatal metabolism. In J. A. F.ERook and P. C. Thomas (Eds.), Nutritional Physiology of Farm Animals, pp. 203-242, Longman, London.

Ferguson, J. D. and K. A. Otto. 1989. Managing Body condition in Dairy cows. Proceedings of the 1989 Cornell Nutrition Conference for feed manufacturers. Pg 75-87, Cornell University, Ithaca, NY 1989.

Ferguson, J. D., D. T. Galligan, and N. Thomsen. 1994. Principal descriptors of Body Condition Score in Dairy cows. J. Dairy Sci. 77:2695-2703.

Ferguson, J. D. 1996. Implementation of a Body Condition Program in Dairy Herds. Proceedings of the Penn Annual Conference, University of Pennsylvania school of Veterinary medicine, Kennett Square, PA.

Ferguson, J.D. 1996. Milk Urea Nitrogen. Center for Animal Health and Productivity, New Bolton Center.

Gearhart, M. A., C. R. Curtis, H. N. Erb, R.D. Smith, C.J. Sniffen, L. E. Chase, and M.D. Cooper. 1990. Relationship of changes in condition score to cow health in Holsteins. J. Dairy Sci. 73:3132-3140. 
Goff, J.P., R.L. Horst, F.J. Mueller, J.K. Miller, G.A. Kiess and H.H. Dowlin. 1991. Addition of chloride to a prepartal diet high in cations increases 1,25dihydroxyvitamin D response to hypocalcemia preventing milk fever. J. Dairy Sci. 74: 3863-3871.

Goff, J. P., and R. L. Horst. 1996. Reducing Metabolic Disease in the Dry Period- Theory and Practical Guidelines. Proc., New England Dairy Feed Conf. and Nutrition and Feed Control Seminar. West Lebanon, N.H.

Goff, J. P., and R. L. Horst. 1997. Effects of the Addition of Potassium or Sodium, but not Calcium, to prerpartum Rations on Milk Fever in Dairy Cows. J. Dairy Sci. 80: 176-186.

Goff. J. P. And R. L. Horst. 1998. Use of Hydrochloric Acid as a source of Anions for Prevention of Milk Fever. J. Dairy Sci. 81: 2870-2880.

Goings, R. L., N. L. Jacobson. D. C. Beitz, E. T. Littledike, and K. D. Wiggers. 1974. Prevention of parturient paresis by a prepartum, calcium deficient diet. J. Dairy Sci. 57: 1184.

Grant, R. J. And J.F. Keown. 1990. Nutritional management of the High-producing dairy Cow in the 1990s. University Nebraska (NebGuide) Extension service \# G90-999A.

Griswold, K.E. W.H. Hoover, T.K. Miller and W. V. Thayne. 1996. Effect of form of nitrogen on growth of ruminal microbes in continuous culture. J. Anim. Sci. 74: 483491.

Grummer, R. R. 1995. Impact of changes in organic nutrient metabolism on feeding the transition dairy cow. J. Anim. Sci. 73: 2820-2833.

Grummer, R. R., P. C. Hoffman and M. L. Luck. 1995. Effect of prepartum and postpartum dietary energy on growth and lactation of primiparous cows. J. Dairy Sci. 78: 172-80.

Grummer, R. R. and D. Minor. 1996. Carbohydrate nutrition of the transition cow. Dairy Profit Report, University of Wisconsin Vol. 8, No 8. Pg 4-7.

Hall, M.B. 1994. Pectin, the structural non-structural carbohydrate. Proc. Cornell Nutr.Conf. pg. 29.

Harris, B. Jr. 1995.MUN and BUN values can be valuable management tools. Feedstuffs 67 (47):14

Harris, B. Jr., 1993. Nonstructural and Structural Carbohydrates in Dairy Cattle Rations. Univ. of Florida, Cooperatvie Extension Service Circular 1122.

Harris, B. Jr. 1992. Feeding the Dairy Cattle Herd. Univ. of Florida Cooperative Extension Service Circular 594. 
Harris, B. Jr. 1992. Feeding for maximum milk production and reproductive performance. Univ. of Florida Cooperative Extension Service Circular 914.

Harrison, G.A., R.W. Hemkin, K.A. Dawson, R.J. Harmon and K.B. Baker. 1988. Influence of addition of Yeast culture supplement to diets of lactating cows on ruminal fermentation and microbial populations. J. Dairy Sci. 71: 2967-2975.

Heinrichs, A. J., V. A. Ishler and R. S. Adams. 1989. Feeding and managing dry cows. PennState College of Agricultural, Cooperative Extension Circular 372.

Helmer, J.G. and E.E. Bartley. 1971. Progress in the utilization of urea as a protein replacer for ruminants. A Review. J. Dairy Sci. 52: 25-51.

Herrera-Saldana, R. And J. T. Huber. 1989. Influence of varying protein and starch degradabilities on performance of lactating cows. J. Dairy Sci. 1477-1483.

Herrera-Saldana, R. E., J. T. Huber and M. H. Poore. 1990. Dry Matter, Crude Protein, and Starch Degradability of five Cereal Grains. J. Dairy Sci. 73: 2386-2393.

Hino, T. and J.B. Russell. 1987. Ralative contributors of ruminal bacteria and protozoa to the degradation of protein in vitro. J. Anim.Sci. 64: 261-266.

Hof, G., M. D. Vervoorn, P. J. Lenaers and S. Tamminga. 1997. Milk Urea Nitrogen as a tool to monitor the protein nutrition of Dairy cows. J. Dairy Sci. 80: 3333-3340.

Hoover, W.H. and S.R. Stokes. 1991. Balancing carbohydrates and proteins for optimum rumen microbial yield. J. Dairy Sci. 74: 3630-3641.

Hoover W. H. and T. K. Miller. 1993. Evaluation of Proteferm as a nitrogen source for rumen microbes. J. Dairy Sci. 76:(Suppl. 1): 178.

Hoover, W.H., T.K. miller and W.V. Thayne. 1994. Effect of Yeast addition on microbial metabolism in continuous culture. J. Dairy Sci. 72: (Suppl. 2) 127.

Hoover, W. H, and T. K. Miller. 1995. Optimizing Carbohydrate fermentation in the rumen. Pro. $6^{\text {th }}$ Annual Florida Nutrition Symp. University of Florida, Gainesville. PP 87.

Hoover, W.H. and T.K. Miller. 1996. Feeding for maximum rumen function. Proc. 1996 Midsouth Ruminant Nutrition conference. Dallas-Fort worth, TX.

Hoover, W.H. and T.K. Miller-Webster. 1996. Contributions of microbial protein to amino acid supply. Proc. Cornell Conf. For Feed mfgrs. Rochester, NY. 
Hoover, W. H and T. K. Miller-Webster 1998. Managing the Rumen For Maximum Efficiency: Kruuse Symposium for Kraegpraktiserende dyrlaeger, May 1998, Denmark. (Proc.Kruuse Symposium on the Dry Cow. Copenhagen, Denmark).

Hoover, W. H and T. K. Miller 1998. Role of Sugars and Starch in Ruminal Fermentation. Proc. Tri-state Dairy Nutrition Conference, Grand Wayne Center, Ft. Wayne, Indiana Pg $1-16$.

Hoover, W. H., T. K. Miller-Webster, W. V. Thayne, W. E. Julien and L. K. Schlatter. 1998. BioChlor and Nutro Cal in dry cows. J. Dairy Sci. 70: Northeast Abstracts.

Huyler, M. T., R.L.Kincaid, and D.F. Dostal. 1999. Metabolic and yield Responses of Multiparous Holstein Cows to Prepartum Rumen-undegradable Protein. J. Dairy Sci. 82: 527-536.

Jardon, P. W. 1995. Using urine $\mathrm{pH}$ to monitor anionic salt programs. Compend. Cont.Educ.Pract. Vet. 17:860.

Jones, D. F., W. H. Hoover and T. K. Miller-Webster.1998. effects of Concentrations of Peptides on Microbial Metabolism in continuous culture. J. Anim. Sci.76: 611616

Joyce, P. W., W. K. Sanchez, and J. P. Goff. 1997. Effect of Anionic Salts in Prepartum Diets Based on Alfalfa. J. Dairy Sci. 80: 2866-2875.

Kandylis, K. 1984. Toxicology of sulfur in ruminants : Review. J. Dairy Sci. 67:2179-2187.

Kaneene, J. B., R. Miller, T. H. Herdt, and J. C. Gardiner. 1997. The Association of Serum Nonesterified Fatty-acids and Cholesterol, Management and Feeding Practices with Peripartum Disease in Dairy Cows. Preventive Veterinary Medicine 31: (1-2), 59-72.

Kertz, A. F., L. F. Reutzel, B. A. Barton, and R. L. Ely. 1997. Body Weight, Body Condition Score, and Wither Height of Prepartum Holstein cows and birth weight and sex of calves by parity. A database and summary. J. Dairy Sci. 80: 525-529.

Komaragiri, M. V. S., and R. A. Erdman. 1997. Factors affecting body tissue mobilization in early lactation dairy cows. 1 . Effect of dietary protein on mobilization of body fat and protein. J. Dairy Sci. 80: 929-937.

Lema, M., W.B. Tucker, M. Aslam, I.S. Shin, P. LeRuyet, and G.D. Adams. 1992. Influence of calcium chloride fed prepartum on severity of edema and lactational peformance of dairy heifers. J. Dairy Sci. 75:2388-2393.

Linn, J. and A. Garcia. 1998. Practical consideration for Monitoring Milk Urea Nitrogen. Proc. Tri-State Dairy Nutrition Conference, Grand Wayne Center, Ft. Wayne, IN. April 1998 Pg 205-215. 
Madsen, J. And T. Hvelplund. 1988. The influence of different protein supply and feeding levels on $\mathrm{pH}$, ammonia concentration and microbial protein synthesis in the rumen of cows. Acta Agric. Scand. 38:115.

Marquardt, J. P., R. L. Horst and N. A Jorgensen. 1977. Effect of Parity on dry matter intake at parturition in dairy cattle. J. Dairy Sci. 60: 929.

McCarthy, R.D., Jr. T. H. Klusmeyer, J. L. Vicini, J. H. Clark, and D.R. Nelson. 1989. Effects of source of protein and carbohydrate on ruminal fermentation and passage of nutrients to the small intestine of lactating cows. J. Dairy Sci. 72: 2002-2016.

McNeill, D. M., R. Slepetis, R. A. Ehrhardt and A. W. Bell. 1994. Protein Requirements in Late Pregnancy: Partitioning of Nitrogen between Gravid uterus and Maternal tissues. Proc. Cornell Nutrition Conf. Cornell Univ. Ithaca. NY. pp117-123.

Mertens, D. R. 1985. Effects of fiber on feed quality for dairy cows. Proc. $46^{\text {th }}$ Minnesota Nutritional Conference, University of Minnesota.

Miller, T. K., W. Hoover, W. E. Julien and W. V.Thayne. 1996. Effects of using BioChlor as a protein source for lactating dairy cattle. J. Dairy Sci. (Suppl 1): 238.

Miller, T. K., W. H. Hoover, W.W Poland, Jr., R. W. Wood and W. V.Thayne. 1990. Effects of low and high fill diets on intake and milk production in dairy cows. J.Dairy Sci. 73: 2453.

Morrow ,D. A., D.Hillman, A.W. Dado, H. Kitchen. 1979. Clinical investigation of a airy herd with the fat cow syndrome. J. Am. Vet. Med. Assoc. 174: 161-167.

National Research Council. 1985. Ruminant Nitrogen usage. National Academy press. Washington D.C

National Research Council. 1989. Nutrient requirements of dairy cattle. Sixth revised edition, National Academy press Washington D.C

Nocek, J.E., C.W. Heald and C.E. Polan. 1984. Influence of ration physical form and nitrogen availability on ruminal morphology of growing bull calves J. Dairy Sci. 67: 34.

Nocek, J. E. and J. B. Russell. 1988. Protein and energy as an integrated system. Reltationship of ruminal protein and carbohydrate availability to synthesis and milk production. J. Dairy Sci. 71: 2070.

O'Connor, J.J., Jr. and P.A. Oltenacu. 1988. Determination of optimum drying-off time for dairy cows using decision analysis and computer simulation. J. Dairy Sci. 71: 3080-3091. 
Oetzel, G. R., M. J. Fettman. D. W. Hamar, and J. D. Olson. 1991. Screening of Anionic salts for palatability, Effects on Acid-base Status, and Urinary Calcium Excretion in Dairy Cows. J. Dairy Sci. 74:965-971.

Oetzel, G. R., J. A. Barmore. 1993. Intake of a Concetrate Mixture Containing Various Anionic Salts fed to pregnant, nonlactating Dairy Cows. J. Dairy Sci. 76;1617-1623.

Official methods of analysis, Agricultural Chemicals. Vol. I, 15 ${ }^{\text {th }}$ edition1990 (AOAC).

Oltner, R. and H. Wiktorsson. 1983. Urea Concentration in milk and blood as influenced by feeding varying amounts of protein and energy to dairy cows. Livest. Prod. Sci. 10: 457- 467.

Putnam, D. E., and G. A. Varga.1998. Protein density and its influence on metabolite concentration and nitrogen retention by Holstein cows in late gestation. J. Dairy Sci. 81: 1608-1618.

Quigley J. D. And J. J. Drewry. 1998. Nutrient and Immunity-transfer from cow to calf precalving and postcalving. J. Dairy Sci. 81: 2779-2790.

Robinson, P. 1997. Effect of Yeast culture (Saccharomyces cereviciae) on adaptation of cows to diets postpartum. J. Dairy Sci. 80:1119-1125.

Roffler, R. E. and D. L. Thacker. 1983. Influence of Reducing Dietary Crude Protein from 17 to $13.5 \%$ on Early lactation. J. Dairy Sci. 66: 51- 58.

Roffler, R. E. and D. L. Thacker. 1983. Early lactation response to supplemental protein by Dairy cows fed grass-legume forage. J. Dairy Sci. 66: 2100- 2108.

Roseler, D. K., J. D. Ferguson, C. J. Sniffen and J. Herrema. 1993. Dietary Protein Degradability effects on Plasma and Milk Urea Nitrogen and Non-Protein Nitrogen in Holstein Cows. J. Dairy Sci. 76: 525-534.

Russell. J.B. 1983. Fermentation of Peptides by Bacteroides ruminicola B, 4. Appl. Environ. Microbiol. 45:1566-1574.

Sanchez, W.K. and D.K. Beede. 1994. Cation-anion concepts for lactating dairy rations. Proceedings, Conf. on Cation-Anion Applications for lactating Cattle. Rochester, NY.

Sander, E. G., R. G. Warner, H. N. Harrison and J. K. Loosli. 1959. The Stumilatory effect of Sodium Butyrate and Sodium Propionate on the Development of Rumen Mucosa in young Calf. J. Dairy Sci. 42: 1600-1605.

Shaver, R. D. 1997. Nutritional Risk-factors in the Etiology of left Displaced Abomasum in dairy cows. A Review. J. Dairy Sci. 80: 2449-2453. 
Smith, D. 1969. Removing and analyzing total nonstructural carbohydrates from plant tissue. Wisconsin Agric. Exp. Sta. Res. Rep. 41:1

Soder, K.J., and L.A. Holden. 1999. Dry matter intake and milk yield and composition of cows fed yeast prepeartum and postpartum. J. Dairy Sci. 82:605-610.

Stokes, S. R., W. H. Hoover, T. K. Miller and R. Blauweikel. 1991a. Ruminal Digestion and Microbial Utilization of Diets varying in type of carbohydrate and Protein. J.Dairy Sci. 74: 871-881.

Stokes, S.R., W.H. Hoover, T.K. Miller and R.P. Mansky. 1991b. Impact of carbohydrate and protein level on bacterial metabolism in continuous culture. J. Dairy Sci. 74: 860870 .

The determination of crude fat in feed using the SOXTEC System HT. The Tecator Journal of technology for chemical analysis, Vol. 9. No 2, 1986.

Tucker, W.B., J.F. Hogue, D.F. Waterman, T.S. Swerson, Z. Xin, R.W. Hemken, J.A. Jackson, G.D. Adams and L.J. Spicer. 1991. Role of sulfur and chloride in the dietary cationanion balance equation for lactating dairy cattle. J. Anim. Sci. 69: 1205-1213.

Tucker, W.B., G.A. Harrison and R.W. Hemken. 1988. Influence of dietary cation-anion balance on milk blood urine and rumen fluid in lactating dairy cattle. J. Dairy Sci. 71: 346-354.

Vagnoni, D. B. and G. R. Oetzel. 1998. Effects of Dietary Cation-Anion Difference on the Acid-Base Status of Dry Cows. J. Dairy Sci. 81:1643-1652.

Varga, G. A., and W. H. Hoover. 1983. Rate and extent of neutral detergent fiber degradation of feedstuffs in situ. J. Dairy Sci. 66. 2109.

Van Suan, J. R. and C. J. Sniffen. 1993. Nutritional Management of the pregnant cow to optimize health, lactation and reproductive performance. Proc. $28^{\text {th }}$ Annual Pacific Northwest Nutrition Conference, Boise, Idaho.

Van Suan, J. R., S. C. Idleman and C. J. Sniffen. 1993. Effect of Undegradable Protein Amount Fed Prepartum on Postpartum Production in First Lactation Holstein Cows. J. Dairy Sci. 76: 236-244.

Wallace, R.J. and M.L. Brammall. 1985. The role of different species of bacteria in the hydrolysis of protein in the rumen. J. Gen. Microbiol. 131: 821-827.

Wang, C. and D.K. Beede. 1992. Effect of ammonium chloride and sulfate on acid-base status and calcium metabolism of dry Jersey cows. J. Dairy Sci. 75: 820-828. 
Wildman, E.E., G. M. Jones, P. E. Wagner, and R.L. Boman H. F. Troutt, Jr., and T.N. Lesch. 1982. A Dairy Cow Body Condition Scoring System and Its Relationship to selected Production Characteristics. J. Dairy Sci. 65: 495-501.

Wilson, R. C, T. R. Overton, and J. K. Clark. 1998. Effects of Yucca Shidigera Extract and Soluble Protein on the performance of Cows and concentrations of Urea Nitrogen in Plasma and Milk. J. Dairy Sci. 81: 1022-1027.

Wohlt, J.E., A.D. Finklestein and C.H. Chung. 1991. Yeast culture to improve intake, nutrient digestibility and performance by dairy cattle during early lactation. J. Dairy Sci. 74: 1395-1400.

Wu, Z., R. J. Fisher, C. E. Polan and C. G. Schwab.1997. Lactational performance of cows fed low or high ruminally undergradable protein prepartum and supplemental methionine and lysine postpartum. J. Dairy Sci. 80: 722-729.

Zamet, C. N., V. F. Colenbrander, C. J. Callahan, B. P. Chew, R. E. Erb, and N. J. Moeller. 1979. Variables associated with peripartum traits in dairy cows. I. Effect of dietary forage and disorders on voluntary intake of feed, body weight and milk yield. Theriogenology 11:229-244. 


\section{APPENDIX}

Appendix Table 1. Effect of Fermenten on acid detergent fiber (ADF), organic matter (OM) and fat intake before and after calving. ${ }^{1}$

\begin{tabular}{|c|c|c|c|c|c|c|}
\hline & \multirow[b]{3}{*}{ Week } & \multirow{2}{*}{\multicolumn{3}{|c|}{ Diets $^{2}$}} & \multicolumn{2}{|c|}{ Contrasts } \\
\hline & & & & & \multirow{2}{*}{$\begin{array}{l}\text { control vs } \\
\text { treatment }\end{array}$} & \multirow{2}{*}{$\begin{array}{c}\text { high vs } \\
\text { low }\end{array}$} \\
\hline & & Control & Lowferm & Highferm & & \\
\hline ADF intake & -3 & 2.89 & 2.18 & 1.94 & $\begin{array}{c}--------- \\
\quad * * *\end{array}$ & ------- \\
\hline \multirow[t]{3}{*}{$\mathrm{kg} / \mathrm{d}$} & -2 & 2.61 & 2.24 & 2.03 & $*$ & ---- \\
\hline & -1 & 2.44 & 1.69 & 1.75 & $* * *$ & ---- \\
\hline & Mean & 2.65 & 2.04 & 1.91 & & \\
\hline \multirow[t]{7}{*}{ Lactation } & 1 & 2.39 & 1.31 & 1.69 & $* *$ & ---- \\
\hline & 2 & 2.97 & 2.29 & 2.16 & $* *$ & ---- \\
\hline & 3 & 3.24 & 2.52 & 2.33 & $* *$ & ---- \\
\hline & 4 & 3.31 & 2.73 & 2.49 & $* *$ & ---- \\
\hline & 5 & 3.70 & 2.99 & 2.76 & $* *$ & ---- \\
\hline & 6 & 3.78 & 2.85 & 3.03 & $* *$ & ---- \\
\hline & Mean & 3.23 & 2.45 & 2.41 & & \\
\hline Organic & -3 & 11.49 & 8.89 & 7.16 & $* * *$ & $*$ \\
\hline Matter & -2 & 10.49 & 9.03 & 7.43 & $* *$ & ---- \\
\hline \multirow[t]{2}{*}{ Intake $\mathrm{Kg} / \mathrm{d}$} & -1 & 10.11 & 7.19 & 6.26 & $* * *$ & ---- \\
\hline & Mean & 10.70 & 8.37 & 6.95 & & \\
\hline \multirow[t]{7}{*}{ Lactation } & 1 & 12.34 & 7.93 & 9.33 & $* *$ & ---- \\
\hline & 2 & 15.48 & 12.53 & 11.75 & $*$ & ---- \\
\hline & 3 & 16.58 & 13.86 & 12.47 & $*$ & ---- \\
\hline & 4 & 17.10 & 15.07 & 13.67 & ---- & ---- \\
\hline & 5 & 18.47 & 15.46 & 14.02 & $* *$ & ---- \\
\hline & 6 & 19.06 & 15.68 & 16.30 & $*$ & ---- \\
\hline & Mean & 16.51 & 13.42 & 12.92 & & \\
\hline \multirow{4}{*}{$\begin{array}{l}\text { Fat intake } \\
\mathrm{kg} / \mathrm{d}\end{array}$} & -3 & 0.21 & 0.19 & 0.15 & $* * *$ & $* *$ \\
\hline & -2 & 0.19 & 0.19 & 0.16 & ---- & ---- \\
\hline & -1 & 0.19 & 0.15 & 0.13 & $* *$ & ---- \\
\hline & Mean & 0.20 & 0.18 & 0.15 & & \\
\hline \multirow[t]{7}{*}{ Lactation } & 1 & 0.28 & 0.17 & 0.23 & $*$ & ---- \\
\hline & 2 & 0.36 & 0.29 & 0.30 & ---- & ---- \\
\hline & 3 & 0.38 & 0.31 & 0.32 & ---- & ---- \\
\hline & 4 & 0.40 & 0.34 & 0.35 & ---- & ---- \\
\hline & 5 & 0.43 & 0.36 & 0.38 & ---- & ---- \\
\hline & 6 & 0.44 & 0.35 & 0.41 & & \\
\hline & Mean & 0.38 & 0.30 & 0.33 & & \\
\hline
\end{tabular}

${ }^{1}$ Least square means

${ }^{2}$ Diet: control $=$ no Fermenten, Lowferm $=0.73 \mathrm{~kg}$ Fermenten DM $/ \mathrm{d}$

Highferm $=1.45 \mathrm{~kg}$ Fermenten $\mathrm{DM} / \mathrm{d}, * * * \mathrm{P}<0.01, * * \mathrm{P}<0.05, \quad * \mathrm{P}<0.1$ 
Appendix Table 2. Effect of Fermenten on intake of starch and sugar before and after calving. ${ }^{1}$

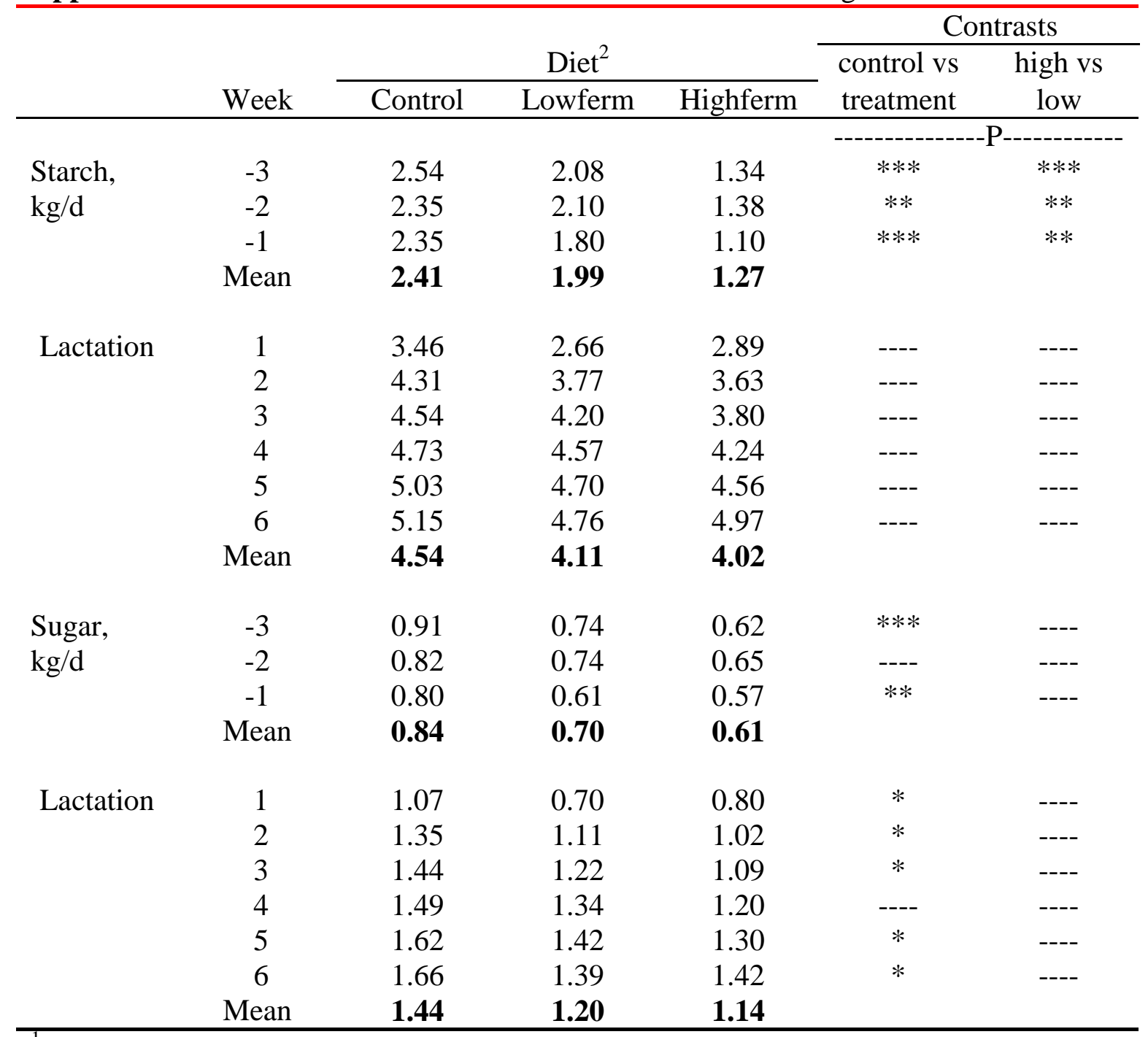

\footnotetext{
${ }^{1}$ Least square means

${ }^{2}$ Diets: control $=$ no Fermenten, Lowferm $=0.73 \mathrm{~kg}$ Fermenten DM $/ \mathrm{d}$

Highferm $=1.45 \mathrm{~kg}$ Fermenten DM/d

$* * * \mathrm{P}<0.01$

$* * \mathrm{P}<0.05$

$* \mathrm{P}<0.10$
} 
Appendix Table 3. Fat and Protein yields (Kg/d) during 6 weeks lactation.

\begin{tabular}{|c|c|c|c|c|c|c|}
\hline & \multirow[b]{3}{*}{ Week } & & & & \multicolumn{2}{|c|}{ Contrasts } \\
\hline & & \multicolumn{3}{|c|}{ Diet $^{2}$} & \multirow{2}{*}{$\begin{array}{l}\text { control vs } \\
\text { treatment }\end{array}$} & \multirow{2}{*}{$\begin{array}{c}\text { high vs } \\
\text { low }\end{array}$} \\
\hline & & Control & Lowferm & Highferm & & \\
\hline & & & & & ---------- & --------- \\
\hline \multirow{7}{*}{$\begin{array}{l}\text { Fat yield, } \\
\mathrm{Kg} / \mathrm{d}\end{array}$} & 1 & 1.25 & 0.49 & 0.74 & ---- & ---- \\
\hline & 2 & 1.29 & 1.03 & 0.99 & ---- & ---- \\
\hline & 3 & 1.37 & 1.12 & 0.99 & $* *$ & ---- \\
\hline & 4 & 1.19 & 0.68 & 0.79 & $*$ & ---- \\
\hline & 5 & 1.34 & 1.05 & 1.07 & $* *$ & ---- \\
\hline & 6 & 1.18 & 0.91 & 1.00 & $*$ & ---- \\
\hline & Mean & 1.27 & 0.88 & 0.93 & & \\
\hline \multirow{7}{*}{$\begin{array}{l}\text { Protein } \\
\text { yield } \\
\text { Kg/d }\end{array}$} & 1 & 0.95 & 0.34 & 0.44 & $* *$ & ---- \\
\hline & 2 & 1.02 & 0.78 & 0.84 & $*$ & ---- \\
\hline & 3 & 1.02 & 0.83 & 0.83 & $*$ & ---- \\
\hline & 4 & 0.94 & 0.88 & 0.83 & ---- & ---- \\
\hline & 5 & 0.99 & 0.88 & 0.84 & ---- & ---- \\
\hline & 6 & 1.00 & 0.83 & 0.90 & $* *$ & ---- \\
\hline & Mean & 0.99 & 0.76 & 0.78 & & \\
\hline
\end{tabular}

${ }^{1}$ Least squares means

${ }^{2}$ Diets: control $=$ no Fermenten, Lowferm $=0.73 \mathrm{~kg}$ Fermenten DM/d, Highferm $=1.45 \mathrm{~kg}$ Fermenten DM/d

$* * \mathrm{P}<0.05$

$* \mathrm{P}<0.10$ 
Appendix Table 4. Data used to calculate least square mean of dry matter intake prepartum and 6 weeks postpartum ${ }^{1}$.

\begin{tabular}{|c|c|c|c|c|c|c|c|}
\hline Trt & Brd & DCI1 & DCI2 & DCI3 & & & \\
\hline 1 & 2 & 11.47 & 11.52 & 8.84 & & & \\
\hline 1 & 1 & 11.82 & 11.12 & 11.36 & & & \\
\hline 1 & 1 & 14.52 & 14.35 & 12.38 & & & \\
\hline 1 & 1 & 11.95 & 11.79 & 11.13 & & & \\
\hline 1 & 1 & 12.36 & 11.69 & 11.73 & & & \\
\hline 1 & 2 & 11.29 & 7.51 & 9.22 & & & \\
\hline 2 & 1 & 10.62 & 10.91 & 9.08 & & & \\
\hline 2 & 1 & 7.09 & 6.81 & 4.5 & & & \\
\hline 2 & 1 & 9.20 & 12.27 & 7.8 & & & \\
\hline 2 & 1 & 9.77 & 11.48 & 8.95 & & & \\
\hline 2 & 1 & 12.09 & 11.08 & 7.96 & & & \\
\hline 2 & 1 & 9.47 & 9.31 & 9.11 & & & \\
\hline 3 & 2 & 8.66 & 8.88 & 8.95 & & & \\
\hline 3 & 1 & 5.63 & 5.6 & 4.1 & & & \\
\hline 3 & 1 & 9.12 & 11.51 & 7.38 & & & \\
\hline 3 & 2 & 6.69 & 6.85 & 6.31 & & & \\
\hline 3 & 1 & 9.4 & 9.99 & 10.06 & & & \\
\hline 3 & 1 & 6.49 & 5.82 & 3.51 & & & \\
\hline Trt & Brd & LCI1 & LCI2 & LCI3 & LCI4 & LCI5 & LCI6 \\
\hline 1 & 2 & 10.44 & 13.02 & 13.57 & 15.84 & 16.92 & 17.19 \\
\hline 1 & 1 & 11.95 & 13.68 & 16.13 & 17.9 & 17.88 & 18.39 \\
\hline 1 & 1 & 15.45 & 21.49 & 22.24 & 23.12 & 24.15 & 23.55 \\
\hline 1 & 1 & 13.64 & 16.51 & 17.31 & 17.86 & 18.27 & 19.18 \\
\hline 1 & 1 & 14.38 & 18.48 & 19.99 & 21.51 & 23.74 & 24.23 \\
\hline 1 & 2 & 14.62 & 17.26 & 18.34 & 15.84 & 20.83 & 22.39 \\
\hline 2 & 1 & 12.29 & 14.19 & 15.67 & 17.43 & 18.69 & 19.28 \\
\hline 2 & 1 & 2.96 & 7.29 & 9.93 & 11.1 & 11.72 & 14.04 \\
\hline 2 & 1 & 2.69 & 12.51 & 14.73 & 19.69 & 22.41 & 16.87 \\
\hline 2 & 1 & 15.29 & 19.18 & 20.42 & 20.53 & 21.3 & 22.72 \\
\hline 2 & 1 & 10.86 & 16.27 & 17.16 & 19.2 & 17.93 & 17.25 \\
\hline 2 & 1 & 10.07 & 13.65 & 13.97 & 15.1 & 16.23 & 17.46 \\
\hline 3 & 2 & 10.6 & 15.14 & 16.18 & 15.52 & 15.35 & 16.68 \\
\hline 3 & 1 & 9.01 & 9.82 & 6.24 & 8.55 & 13.48 & 15.2 \\
\hline 3 & 1 & 11.04 & 12.67 & 15.84 & 18.57 & 20.23 & 24.16 \\
\hline 3 & 2 & 8.69 & 11.39 & 12.48 & 14.79 & 15.15 & 15.21 \\
\hline 3 & 1 & 15.03 & 18.44 & 19.78 & 20.56 & 20.53 & 22.28 \\
\hline 3 & 1 & 6.4 & 9.1 & 10.81 & 12.14 & 12.87 & 13.85 \\
\hline
\end{tabular}

${ }^{1} \mathrm{DCI}=$ dry period intake, $\mathrm{LCI}=$ lactation period intake, $\mathrm{Trt}=$ treatment group, $\mathrm{Brd}=$ breed $(1=$ Holstein,

$2=$ Ayrshire). 
Appendix Table 5. Data used to calculate least square mean for milk yield for 6 weeks postpartum $(\mathrm{Kg})^{1}$.

\begin{tabular}{cccccccc}
\hline Trt & Brd & MK1 & MK2 & MK3 & MK4 & MK5 & MK6 \\
\hline 1 & 2 & 19.49 & 31.10 & 31.62 & 30.42 & 32.48 & 33.62 \\
1 & 1 & 22.39 & 28.42 & 32.41 & 34.64 & 34.69 & 33.12 \\
1 & 1 & 24.11 & 36.95 & 38.66 & 37.06 & 37.23 & 37.6 \\
1 & 1 & 19.10 & 32.15 & 34.69 & 36.23 & 37.70 & 36.42 \\
1 & 1 & 31.80 & 41.88 & 41.63 & 41.38 & 44.50 & 46.59 \\
1 & 2 & 13.78 & 22.73 & 24.84 & 23.32 & 25.87 & 26.16 \\
2 & 1 & 23.58 & 31.97 & 33.26 & 35.11 & 36.14 & 34.89 \\
2 & 1 & 7.68 & 13.63 & 19.38 & 21.75 & 23.58 & 24.88 \\
2 & 1 & 11.95 & 18.05 & 25.13 & 29.21 & 30.58 & 23.39 \\
2 & 1 & 27.10 & 35.68 & 36.66 & 38.34 & 36.40 & 35.31 \\
2 & 1 & 16.94 & 24.97 & 27.83 & 29.27 & 27.75 & 26.35 \\
2 & 1 & 14.52 & 27.29 & 27.9 & 30.61 & 31.95 & 32.67 \\
3 & 2 & 20.55 & 26.9 & 29.53 & 28.94 & 30.28 & 29.51 \\
3 & 1 & 16.1 & 21.35 & 15.85 & 17.63 & 24.92 & 27.38 \\
3 & 1 & 17.99 & 24.34 & 29.02 & 33.62 & 35.00 & 35.02 \\
3 & 2 & 17.00 & 26.74 & 27.00 & 27.73 & 27.86 & 27.52 \\
3 & 1 & 25.52 & 32.90 & 35.69 & 37.54 & 36.22 & 34.12 \\
3 & 1 & 10.56 & 18.90 & 22.54 & 23.68 & 23.23 & 24.35 \\
\hline
\end{tabular}

${ }^{\mathrm{T}} \mathrm{MK}=$ milk yield in $\mathrm{kg} / \mathrm{d}, \mathrm{Trt}=$ treatment group, Brd $=$ breed $(1=$ Holstein, $2=$ Ayrshire $)$

Appendix Table 6. Data used to calculate least square mean for $4 \%$ Fat corrected milk

\begin{tabular}{llllllll}
\multicolumn{7}{c}{$(\text { FCM })^{1}$} & \\
\hline Trt & Brd & FCM1 & FCM2 & FCM3 & FCM4 & FCM5 & FCM6 \\
\hline 1 & 2 & 32.24 &. & 37.85 & 30.92 & 30.99 & 31.6 \\
1 & 1 &. & 30.12 & 31.41 & 30.51 & 35.78 & 28.1 \\
1 & 1 &. & 37.43 & 35.71 & 34.78 & 36.64 & 35.29 \\
1 & 1 &. & 28.31 & 32.03 & 30.84 & 32.63 & 31.52 \\
1 & 1 & 33.27 & 43.75 & 40.95 & 39.5 & 41.8 & 44.44 \\
1 & 2 & 14.6 & 23.42 & 25.99 & 23.67 & 28.2 & 22.62 \\
2 & 1 &. & 34.54 &. & 32.49 & 30.65 & 27.61 \\
2 & 1 &. & 16.85 & 17.95 & 21.15 & 21.13 & 21.95 \\
2 & 1 &. & 15.02 & 22.5 & 25.33 & 27.83 & 19.85 \\
2 & 1 &. & 34.67 & 36.71 & 35.44 & 33.61 & 33.17 \\
2 & 1 & 15.92 & 26.1 & 27.41 & 27.52 & 25.67 & 24.37 \\
2 & 1 & 15.17 & 29.75 & 31.25 & 31.99 & 30.03 & 30.71 \\
3 & 2 & & 27.26 & 28.61 & 25.53 & 33.86 & 28.15 \\
3 & 1 & 18.74 & 19.79 & 17.29 & 18.45 & 21.52 & 24.45 \\
3 & 1 & 19.64 & 23.54 & 25.56 & 28.0 & 30.8 & 29.31 \\
3 & 2 &. & 27.2 & 25.8 & 23.99 & 25.85 & 26.31 \\
3 & 1 & 28.58 & 32.9 & 33.55 & 34.16 & 35.68 & 32.07 \\
3 & 1 & 12.94 & 20.03 & 21.52 & 21.55 & 19.4 & 22.89 \\
\hline
\end{tabular}

${ }^{\mathrm{I}} \mathrm{FCM}=4 \%$ Fat corrected milk yield $(\mathrm{kg} / \mathrm{d}), \mathrm{Trt}=$ treatment group $\mathrm{Brd}=$ breed $(1=$ Holstein, $2=$ Ayrshire) 
Appendix Table 7a. Data used to calculate crude protein intake mean before calving ${ }^{1}$

\begin{tabular}{lllll}
\hline Trt & Brd & DCP1 & DCP2 & DCP3 \\
\hline 1 & 2 & 1.83 & 1.87 & 1.48 \\
1 & 1 & 1.90 & 1.83 & 1.95 \\
1 & 1 & 2.41 & 2.32 & 2.07 \\
1 & 1 & 1.99 & 1.97 & 1.89 \\
1 & 1 & 2.02 & 1.91 & 1.94 \\
1 & 2 & 1.81 & 1.22 & 1.51 \\
2 & 1 & 1.80 & 1.83 & 1.53 \\
2 & 1 & 1.16 & 1.13 & 0.77 \\
2 & 1 & 1.47 & 1.96 & 1.24 \\
2 & 1 & 1.78 & 1.91 & 1.68 \\
2 & 1 & 2.00 & 1.84 & 1.40 \\
2 & 1 & 1.64 & 1.62 & 1.63 \\
3 & 2 & 1.28 & 1.32 & 1.29 \\
3 & 1 & 0.82 & 0.74 & 0.46 \\
3 & 1 & 1.45 & 1.82 & 1.20 \\
3 & 2 & 0.96 & 0.99 & 0.90 \\
3 & 1 & 1.36 & 1.45 & 1.49 \\
3 & 1 & 0.88 & 0.75 & 0.31 \\
\hline
\end{tabular}

Table 7b. Data used to calculate crude protein intake after calving ${ }^{2}$

\begin{tabular}{llllllll}
\hline Trt & Brd & LCP1 & LCP2 & LCP3 & LCP4 & LCP5 & LCP6 \\
\hline 1 & 2 & 1.86 & 2.29 & 2.40 & 2.79 & 2.96 & 3.02 \\
1 & 1 & 2.12 & 2.43 & 2.82 & 3.15 & 3.15 & 3.22 \\
1 & 1 & 2.71 & 3.76 & 3.90 & 4.05 & 4.22 & 4.12 \\
1 & 1 & 2.42 & 2.94 & 3.06 & 3.15 & 3.22 & 3.37 \\
1 & 1 & 2.53 & 3.28 & 3.49 & 3.76 & 4.14 & 4.24 \\
1 & 2 & 2.55 & 3.02 & 3.20 & 2.79 & 3.63 & 3.90 \\
2 & 1 & 2.16 & 2.47 & 2.72 & 3.03 & 3.24 & 3.34 \\
2 & 1 & 0.58 & 1.28 & 1.75 & 1.94 & 2.34 & 2.28 \\
2 & 1 & 0.37 & 1.90 & 2.23 & 3.00 & 3.41 & 2.53 \\
2 & 1 & 2.68 & 3.37 & 3.56 & 3.62 & 3.73 & 3.98 \\
2 & 1 & 1.89 & 2.84 & 2.99 & 3.35 & 3.12 & 3.01 \\
2 & 1 & 1.71 & 2.33 & 2.38 & 2.58 & 2.78 & 2.99 \\
3 & 2 & 1.86 & 2.66 & 2.83 & 2.75 & 2.71 & 2.91 \\
3 & 1 & 1.54 & 1.67 & 1.05 & 1.46 & 2.31 & 2.61 \\
3 & 1 & 1.93 & 2.21 & 2.74 & 3.23 & 3.52 & 4.19 \\
3 & 2 & 1.52 & 2.00 & 2.18 & 2.57 & 2.64 & 2.66 \\
3 & 1 & 2.58 & 3.16 & 3.38 & 3.52 & 3.52 & 3.82 \\
3 & 1 & 1.12 & 1.59 & 1.88 & 2.12 & 2.24 & 2.41 \\
\hline
\end{tabular}

${ }^{\mathrm{T}} \mathrm{DCP}=$ Dry period intake $\mathrm{kg} / \mathrm{d}, \mathrm{Trt}=$ Treatment group

${ }^{2} \mathrm{LCP}=$ Lactation period intake $\mathrm{kg} / \mathrm{d} \mathrm{Brd}=$ breed (1=Holstein, $2=$ =Ayrshire) 
Appendix table 8a. Data used to calculate

\begin{tabular}{lllll} 
& \multicolumn{4}{c}{ NDF intake 3 weeks prepartum } \\
\hline Trt & Brd & NDF1 & NDF2 & NDF3 \\
\hline 1 & 2 & 5.25 & 5.20 & 3.87 \\
1 & 1 & 5.37 & 4.93 & 4.83 \\
1 & 1 & 6.63 & 6.61 & 5.64 \\
1 & 1 & 5.13 & 5.01 & 4.62 \\
1 & 1 & 5.46 & 5.14 & 5.10 \\
1 & 2 & 5.02 & 3.24 & 3.95 \\
2 & 1 & 4.56 & 4.74 & 3.92 \\
2 & 1 & 3.24 & 3.08 & 1.98 \\
2 & 1 & 4.30 & 5.75 & 3.73 \\
2 & 1 & 3.72 & 5.02 & 3.22 \\
2 & 1 & 5.33 & 4.85 & 3.20 \\
2 & 1 & 4.02 & 3.91 & 3.72 \\
3 & 2 & 4.24 & 4.31 & 4.45 \\
3 & 1 & 2.76 & 2.98 & 2.39 \\
3 & 1 & 3.82 & 5.02 & 2.68 \\
3 & 2 & 3.28 & 3.35 & 3.11 \\
3 & 1 & 4.49 & 4.77 & 4.77 \\
3 & 1 & 3.18 & 2.91 & 1.94 \\
\hline
\end{tabular}

${ }^{1} \mathrm{NDF}=$ dry period intake $\mathrm{kg} / \mathrm{d}$, Trt = treatment group

Brd $=$ breed $(1=$ Holstein, $2=$ Ayrshire $)$

Table 8b. Data used to calculate NDF intake during Lactation ${ }^{2}$.

\begin{tabular}{llllllll}
\hline Trt & Brd & LND1 & LND2 & LND3 & LND4 & LND5 & LND6 \\
\hline 1 & 2 & 3.62 & 4.56 & 4.73 & 5.53 & 5.95 & 6.03 \\
1 & 1 & 3.99 & 4.54 & 5.59 & 6.12 & 6.11 & 6.35 \\
1 & 1 & 5.30 & 7.43 & 7.63 & 8.01 & 8.38 & 8.17 \\
1 & 1 & 4.52 & 5.41 & 5.83 & 6.01 & 6.17 & 6.54 \\
1 & 1 & 4.89 & 6.13 & 6.96 & 7.45 & 8.28 & 8.39 \\
1 & 2 & 5.02 & 5.80 & 6.24 & 5.11 & 7.19 & 7.70 \\
2 & 1 & 4.74 & 5.17 & 5.64 & 6.34 & 6.60 & 6.81 \\
2 & 1 & 0.74 & 2.40 & 3.25 & 3.72 & 3.93 & 4.73 \\
2 & 1 & 0.32 & 4.12 & 4.81 & 6.66 & 8.53 & 5.02 \\
2 & 1 & 4.94 & 6.23 & 6.74 & 6.55 & 6.98 & 7.43 \\
2 & 1 & 3.58 & 5.27 & 5.60 & 6.27 & 5.88 & 5.61 \\
2 & 1 & 3.30 & 4.56 & 4.65 & 5.03 & 5.45 & 5.86 \\
3 & 2 & 3.32 & 4.73 & 5.14 & 4.76 & 4.78 & 5.39 \\
3 & 1 & 3.13 & 3.51 & 2.33 & 3.00 & 4.84 & 5.22 \\
3 & 1 & 3.54 & 4.09 & 5.28 & 6.05 & 6.60 & 7.95 \\
3 & 2 & 2.73 & 3.59 & 4.02 & 4.79 & 4.87 & 4.87 \\
3 & 1 & 5.18 & 6.33 & 6.90 & 7.13 & 7.10 & 7.67 \\
3 & 1 & 2.03 & 2.96 & 3.52 & 3.95 & 4.21 & 4.56 \\
\hline
\end{tabular}

${ }^{2} \mathrm{LND}=$ Lactation NDF intake $\mathrm{kg} / \mathrm{d}$, Trt = Treatment group, Brd = Breed (1=Holstein, 2=Ayrshire) 
Appendix Table 9. Data used to calculate least square means for fat yield in milk $^{1}$

\begin{tabular}{llllllll}
\hline Trt & Brd & FT1 & FT2 & FT3 & FT4 & FT5 & FT6 \\
\hline 1 & 2 & 1.63 &. & 1.68 & 1.25 & 1.20 & 1.21 \\
1 & 1 &. & 1.25 & 1.23 & 1.11 & 1.46 & 0.99 \\
1 & 1 &. & 1.51 & 1.35 & 1.33 & 1.45 & 1.35 \\
1 & 1 &. & 1.03 & 1.21 & 1.09 & 1.17 & 1.13 \\
1 & 1 & 1.37 & 1.80 & 1.62 & 1.53 & 1.60 & 1.72 \\
1 & 2 & 0.61 & 0.96 & 1.07 & 0.96 & 1.19 & 0.81 \\
2 & 1 &. & 1.45 &. & 1.23 & 1.08 & 0.91 \\
2 & 1 &. & 0.76 & 0.68 & 0.83 & 0.78 & 0.81 \\
2 & 1 &. & 0.52 & 0.83 & 0.91 & 1.04 & 0.70 \\
2 & 1 &. & 1.36 & 1.47 & 1.34 & 1.27 & 1.27 \\
2 & 1 & 0.61 & 1.07 & 1.09 & 1.05 & 0.97 & 0.92 \\
2 & 1 & 0.62 & 1.26 & 1.34 & 1.32 & 1.15 & 1.18 \\
3 & 2 &. & 1.10 & 1.12 & 0.93 & 1.45 & 1.09 \\
3 & 1 & 0.82 & 0.75 & 0.73 & 0.76 & 0.77 & 0.90 \\
3 & 1 & 0.83 & 0.92 & 0.93 & 0.97 & 1.12 & 1.02 \\
3 & 2 &. & 1.10 & 1.00 & 0.86 & 0.98 & 1.02 \\
3 & 1 & 1.22 & 1.32 & 1.28 & 1.28 & 1.41 & 1.23 \\
3 & 1 & 0.58 & 0.83 & 0.83 & 0.81 & 0.67 & 0.88 \\
\hline
\end{tabular}

${ }^{\mathrm{I}} \mathrm{FT}=$ Fat yiled in $\mathrm{kg}, \mathrm{Trt}=$ Treatment group, $\mathrm{Brd}=$ Breed $(1=$ Holstein, $2=$ Ayrshire)

Appendix Table 10. Data used to calculate fat percent in milk per cow for six weeks of lactation ${ }^{1}$

\begin{tabular}{llllllll}
\hline Trt & Brd & FP1 & FP2 & FP3 & FP4 & FP5 & FP6 \\
\hline 1 & 2 & 5.23 &. & 5.30 & 4.10 & 3.70 & 3.60 \\
1 & 1 &. & 4.40 & 3.80 & 3.20 & 4.20 & 3.00 \\
1 & 1 &. & 4.10 & 3.50 & 3.60 & 3.90 & 3.60 \\
1 & 1 &. & 3.20 & 3.50 & 3.00 & 3.10 & 3.10 \\
1 & 1 & 4.30 & 4.30 & 3.90 & 3.70 & 3.60 & 3.70 \\
1 & 2 & 4.40 & 4.20 & 4.30 & 4.10 & 4.60 & 3.10 \\
2 & 1 &. & 4.53 &. & 3.50 & 3.00 & 2.60 \\
2 & 1 &. & 5.60 & 3.50 & 3.80 & 3.30 & 3.20 \\
2 & 1 &. & 2.90 & 3.30 & 3.10 & 3.40 & 3.00 \\
2 & 1 &. & 3.80 & 4.00 & 3.50 & 3.50 & 3.60 \\
2 & 1 & 3.60 & 4.30 & 3.90 & 3.60 & 3.50 & 3.50 \\
2 & 1 & 4.30 & 4.60 & 4.80 & 4.30 & 3.60 & 3.60 \\
3 & 2 &. & 4.10 & 3.80 & 3.20 & 4.80 & 3.70 \\
3 & 1 & 5.10 & 3.50 & 4.60 & 4.30 & 3.10 & 3.30 \\
3 & 1 & 4.60 & 3.80 & 3.20 & 2.90 & 3.20 & 2.90 \\
3 & 2 &. & 4.10 & 3.70 & 3.10 & 3.50 & 3.70 \\
3 & 1 & 4.80 & 4.00 & 3.60 & 3.40 & 3.90 & 3.60 \\
3 & 1 & 5.50 & 4.40 & 3.70 & 3.40 & 2.90 & 3.60 \\
\hline
\end{tabular}

${ }^{\mathrm{I}} \mathrm{FP}=$ Fat percent, $\mathrm{Trt}=$ Group treatment, $\mathrm{Brd}=$ Breed $(1=$ Holstein, $2=$ Ayrshire $)$ 
Appendix Table 11. Data used to calculate protein yield per cow per week during lactation period ${ }^{1}$

\begin{tabular}{llllllll}
\hline Trt & Brd & PT1 & PT2 & PT3 & PT4 & PT5 & PT6 \\
\hline 1 & 2 & 0.80 &. & 0.95 & 0.88 & 0.91 & 1.01 \\
1 & 1 & $\cdot$ & 0.82 & 0.94 & 0.94 & 0.87 & 0.96 \\
1 & 1 &. & 1.22 & 1.16 & 1.04 & 1.08 & 1.02 \\
1 & 1 &. & 0.96 & 0.97 & 0.94 & 0.94 & 0.91 \\
1 & 1 & 1.21 & 1.30 & 1.25 & 1.16 & 1.25 & 1.30 \\
1 & 2 & 0.58 & 0.86 & 0.89 & 0.79 & 0.93 & 0.94 \\
2 & 1 &. & 0.98 &. & 0.95 & 0.98 & 0.94 \\
2 & 1 &. & 0.46 & 0.60 & 0.61 & 0.64 & 0.70 \\
2 & 1 &. & 0.65 & 0.83 & 1.05 & 1.01 & 0.77 \\
2 & 1 &. & 1.11 & 1.10 & 1.07 & 1.06 & 1.02 \\
2 & 1 & 0.69 & 0.85 & 0.92 & 0.97 & 0.92 & 0.90 \\
2 & 1 & 0.51 & 0.76 & 0.81 & 0.86 & 0.89 & 0.91 \\
3 & 2 &. & 0.86 & 0.92 & 0.87 & 0.85 & 0.86 \\
3 & 1 & 0.61 & 0.73 & 0.54 & 0.48 & 0.62 & 0.79 \\
3 & 1 & 0.70 & 0.85 & 0.90 & 1.11 & 1.09 & 1.09 \\
3 & 2 &. & 0.91 & 0.84 & 0.83 & 0.84 & 0.83 \\
3 & 1 & 1.02 & 1.02 & 1.11 & 1.05 & 1.05 & 1.02 \\
3 & 1 & 0.46 & 0.68 & 0.74 & 0.71 & 0.67 & 0.88 \\
\hline \multicolumn{7}{l}{ PT = protein yield (kg), Trt= Treatment group, Brd = Breed (1=Holstein, 2=Ayrshire) }
\end{tabular}

Appendix Table 12. Data used to calculate protein percent in milk per cow per week during lactation ${ }^{2}$.

\begin{tabular}{llllllll}
\hline Trt & Brd & PC1 & PC2 & PC3 & PC4 & PC5 & PC6 \\
\hline 1 & 2 & 4.08 &. & 3.03 & 2.90 & 2.80 & 3.00 \\
1 & 1 & $\cdot$ & 2.90 & 2.90 & 2.70 & 2.50 & 2.90 \\
1 & 1 & $\cdot$ & 3.30 & 3.00 & 2.80 & 2.90 & 2.70 \\
1 & 1 &. & 3.0 & 2.80 & 2.60 & 2.50 & 2.50 \\
1 & 1 & 3.80 & 3.10 & 3.00 & 2.80 & 2.80 & 2.80 \\
1 & 2 & 4.20 & 3.80 & 3.60 & 3.40 & 3.60 & 3.60 \\
2 & 1 & $\cdot$ & 3.06 &. & 2.70 & 2.70 & 2.70 \\
2 & 1 & $\cdot$ & 3.40 & 3.10 & 2.80 & 2.70 & 2.80 \\
2 & 1 &. & 3.60 & 3.30 & 3.60 & 3.30 & 3.30 \\
2 & 1 &. & 3.10 & 3.00 & 2.80 & 2.90 & 2.90 \\
2 & 1 & 4.10 & 3.40 & 3.30 & 3.30 & 3.30 & 3.40 \\
2 & 1 & 3.50 & 2.80 & 2.90 & 2.80 & 2.80 & 2.80 \\
3 & 2 &. & 3.20 & 3.10 & 3.00 & 2.80 & 2.90 \\
3 & 1 & 0.80 & 3.40 & 3.40 & 2.70 & 2.50 & 2.90 \\
3 & 1 & 3.90 & 3.50 & 3.10 & 3.3 & 3.10 & 3.10 \\
3 & 2 &. & 3.40 & 3.10 & 3.00 & 3.00 & 3.00 \\
3 & 1 & 4.20 & 3.10 & 3.10 & 2.80 & 2.90 & 3.00 \\
3 & 1 & 4.40 & 3.60 & 3.20 & 3.00 & 2.90 & 2.80 \\
\hline \multicolumn{2}{l}{ PC $=$ percent protein, Trt = treatment group, Brd = breed (1=Holstein, 2=Ayrshire) }
\end{tabular}


Appendix table 13. Data used to calculate least square mean for milk urea nitrogen $\mathrm{mg} / \mathrm{dl}(\mathrm{MUN})^{\mathrm{a}}$

\begin{tabular}{llllllll}
\hline Trt & Brd & MU1 & MU2 & MU3 & MU4 & MU5 & MU6 \\
\hline 1 & 2 & 11 &. & 13 & 17 & 15 & 15 \\
1 & 1 &. & 14 & 16 & 17 & 18 & 16 \\
1 & 1 &. & 11 & 12 & 15 & 13 & 13 \\
1 & 1 &. & 9 & 10 & 10 & 13 & 14 \\
1 & 1 & 10 & 13 & 15 & 16 & 18 & 19 \\
1 & 2 & 13 & 15 & 16 & 15 & 17 & 15 \\
2 & 1 &. & 15 &. & 18 & 19 & 18 \\
2 & 1 &. & 5 & 10 & 11 & 11 & 13 \\
2 & 1 &. & 7 & 13 & 11 & 11 & 12 \\
2 & 1 &. & 13 & 13 & 13 & 23 & 18 \\
2 & 1 & 11 & 18 & 17 & 18 & 19 & 17 \\
2 & 1 & 12 & 14 & 13 & 15 & 18 & 18 \\
3 & 2 &. & 10 & 13 & 13 & 12 & 15 \\
3 & 1 & 8 & 11 & 11 & 10 & 14 & 16 \\
3 & 1 & 7 & 9 & 12 & 15 & 13 & 14 \\
3 & 2 &. & 13 & 17 & 18 & 19 & 18 \\
3 & 1 & 11 & 13 & 15 & 19 & 19 & 18 \\
3 & 1 & 7 & 10 & 14 & 16 & 15 & 15 \\
\hline
\end{tabular}

${ }^{\mathrm{a}} \mathrm{MU}=$ Milk Urea Nitrogen per cow per week Trt $=$ treatment group, $\mathrm{Brd}=$ breed $(1=$ Holstein, $2=$ Ayrshire)

Appendix Table 14. Data used to calculate least square means for Somatic cell counts (SCC) cells $/ \mathrm{ml}$ in milk ${ }^{1}$.

\begin{tabular}{cccccccc}
\hline Trt & Brd & SCC1 & SCC2 & SCC3 & SCC4 & SCC5 & SCC6 \\
\hline 1 & 2 & 802 &. & 58 & 36 & 15 & 8 \\
1 & 1 &. & 17 & 12 & 1 & 3 & 1 \\
1 & 1 &. & 118 & 31 & 6 & 4 & 11 \\
1 & 1 &. & 164 & 69 & 21 & 26 & 15 \\
1 & 1 & 101 & 27 & 248 & 62 & 93 & 66 \\
1 & 2 & 606 & 62 & 162 & 41 & 81 & 27 \\
2 & 1 &. & 50 &. & 6 & 10 & 3 \\
2 & 1 &. & 290 & 41 & 49 & 20 & 10 \\
2 & 1 &. & 300 & 330 & 1449 & 656 & 3743 \\
2 & 1 & & 369 & 281 & 214 & 171 & 138 \\
2 & 1 & 17 & 20 & 13 & 13 & 23 & 17 \\
2 & 1 & 66 & 17 & 17 & 13 & 13 & 17 \\
3 & 2 &. & 4 & 18 & 5 & 6 & 2 \\
3 & 1 & 1595 & 99 & 76 & 28 & 12 & 10 \\
3 & 1 & 166 & 14 & 4 & 13 & 7 & 20 \\
3 & 2 &. & 271 & 76 & 123 & 50 & 54 \\
3 & 1 & 187 & 14 & 13 & 13 & 20 & 17 \\
3 & 1 & 2.425 & 246 & 62 & 27 & 22 & 43 \\
\hline
\end{tabular}

${ }^{1} \mathrm{Trt}=$ group treatment, $\mathrm{Brd}=$ breed $(1=$ Holstein, $2=$ Ayrshire $)$ 
Appendix Table 15a. Data used to calculate least square means for acid detergent fiber intake $(\mathrm{ADF})$ in the dry period ${ }^{1}$

\begin{tabular}{lllll}
\hline Trt & Brd & ADF1 & ADF2 & ADF3 \\
\hline 1 & 2 & 2.82 & 2.78 & 2.04 \\
1 & 1 & 2.88 & 2.63 & 2.53 \\
1 & 1 & 3.34 & 3.43 & 2.82 \\
1 & 1 & 2.75 & 2.68 & 2.47 \\
1 & 1 & 2.94 & 2.77 & 2.75 \\
1 & 2 & 2.70 & 1.73 & 2.11 \\
2 & 1 & 2.40 & 2.51 & 2.07 \\
2 & 1 & 1.71 & 1.62 & 1.02 \\
2 & 1 & 2.28 & 3.04 & 1.95 \\
2 & 1 & 1.95 & 2.67 & 1.68 \\
2 & 1 & 2.84 & 2.59 & 1.70 \\
2 & 1 & 2.11 & 2.05 & 1.94 \\
3 & 2 & 2.27 & 2.31 & 2.40 \\
3 & 1 & 1.47 & 1.59 & 1.29 \\
3 & 1 & 2.15 & 2.77 & 1.66 \\
3 & 2 & 1.76 & 1.79 & 1.67 \\
3 & 1 & 2.39 & 2.53 & 2.53 \\
3 & 1 & 1.69 & 1.55 & 1.05 \\
\hline
\end{tabular}

${ }^{1} \mathrm{ADF}=$ dry period intake $(\mathrm{kg}) \mathrm{Trt}=$ Group treatment, $\mathrm{Brd}=$ breed $(1=$ Holstein, $2=$ Ayrshire $)$

Appendix Table 15b. Data used to calculate least square mean for ADF intakes during lactation ${ }^{2}$

\begin{tabular}{llllllll}
\hline Trt & Brd & LAD1 & LAD2 & LAD3 & LAD4 & LAD5 & LAD6 \\
\hline 1 & 2 & 1.81 & 2.38 & 2.41 & 2.84 & 3.13 & 3.14 \\
1 & 1 & 2.21 & 2.51 & 3.06 & 3.36 & 3.35 & 3.48 \\
1 & 1 & 2.86 & 4.02 & 4.12 & 4.33 & 4.53 & 4.42 \\
1 & 1 & 2.39 & 2.85 & 3.11 & 3.20 & 3.29 & 3.50 \\
1 & 1 & 2.61 & 3.25 & 3.76 & 4.02 & 4.47 & 4.53 \\
1 & 2 & 2.70 & 3.08 & 3.33 & 2.67 & 3.87 & 4.13 \\
2 & 1 & 1.99 & 2.47 & 2.76 & 3.04 & 3.36 & 3.47 \\
2 & 1 & 0.29 & 1.27 & 1.70 & 1.98 & 2.10 & 2.53 \\
2 & 1 & 0.03 & 2.20 & 2.55 & 3.59 & 4.05 & 2.55 \\
2 & 1 & 2.63 & 3.32 & 3.62 & 3.47 & 3.73 & 3.98 \\
2 & 1 & 1.91 & 2.78 & 2.97 & 3.32 & 3.12 & 2.96 \\
2 & 1 & 1.79 & 2.47 & 2.52 & 2.73 & 2.96 & 3.18 \\
3 & 2 & 1.72 & 2.45 & 2.67 & 2.45 & 2.47 & 2.81 \\
3 & 1 & 1.67 & 1.90 & 1.29 & 1.61 & 2.63 & 2.77 \\
3 & 1 & 1.83 & 2.12 & 2.76 & 3.14 & 3.43 & 4.14 \\
3 & 2 & 1.39 & 1.84 & 2.07 & 2.48 & 2.51 & 2.50 \\
3 & 1 & 2.74 & 3.34 & 3.66 & 3.77 & 3.75 & 4.05 \\
3 & 1 & 1.08 & 1.56 & 1.86 & 2.09 & 2.22 & 2.40 \\
\hline${ }^{2}$ LAD $=$ lactation intake, Trt = Group treatment, Brd = breed (1=Holstein, 2=Aryshire)
\end{tabular}


Appendix Table 16a. Data used to calculate least square means for sugar intake in the dry period ${ }^{1}$.

\begin{tabular}{lllll}
\hline Trt & Brd & DSI1 & DSI2 & DSI3 \\
\hline 1 & 2 & 0.85 & 0.85 & 0.65 \\
1 & 1 & 0.87 & 0.81 & 0.83 \\
1 & 1 & 1.07 & 1.06 & 0.92 \\
1 & 1 & 0.90 & 0.89 & 0.84 \\
1 & 1 & 0.92 & 0.87 & 0.88 \\
1 & 2 & 0.86 & 0.58 & 0.72 \\
2 & 1 & 0.86 & 0.87 & 0.73 \\
2 & 1 & 0.53 & 0.52 & 0.35 \\
2 & 1 & 0.69 & 0.93 & 0.61 \\
2 & 1 & 0.82 & 0.89 & 0.77 \\
2 & 1 & 0.92 & 0.85 & 0.63 \\
2 & 1 & 0.72 & 0.71 & 0.70 \\
3 & 2 & 0.70 & 0.71 & 0.73 \\
3 & 1 & 0.43 & 0.42 & 0.31 \\
3 & 1 & 0.73 & 0.91 & 0.62 \\
3 & 2 & 0.57 & 0.58 & 0.55 \\
3 & 1 & 0.78 & 0.83 & 0.82 \\
3 & 1 & 0.57 & 0.54 & 0.41 \\
\hline
\end{tabular}

${ }^{\mathrm{I}} \mathrm{DSI}=$ dry period intake $(\mathrm{kg}) \mathrm{Tr}=$ group treatment, $\mathrm{Brd}=$ breed $(1=$ Holstein, $2=$ Ayrshire $)$

Appendix Table 16b. Data used to calculate least square means for sugar intake in the lactation period $(\mathrm{kg})^{2}$

\begin{tabular}{llllllll}
\hline Trt & Brd & LSI1 & LSI2 & LSI3 & LSI4 & LSI5 & LSI6 \\
\hline 1 & 2 & 0.83 & 1.04 & 1.08 & 1.26 & 1.36 & 1.37 \\
1 & 1 & 0.97 & 1.12 & 1.31 & 1.45 & 1.45 & 1.49 \\
1 & 1 & 1.25 & 1.74 & 1.80 & 1.87 & 1.96 & 1.91 \\
1 & 1 & 1.10 & 1.34 & 1.40 & 1.45 & 1.48 & 1.55 \\
1 & 1 & 1.17 & 1.50 & 1.62 & 1.74 & 1.92 & 1.96 \\
1 & 2 & 1.19 & 1.42 & 1.50 & 1.32 & 1.70 & 1.83 \\
2 & 1 & 1.01 & 1.16 & 1.26 & 1.43 & 1.53 & 1.58 \\
2 & 1 & 0.21 & 0.59 & 0.80 & 0.90 & 0.95 & 1.14 \\
2 & 1 & 0.22 & 1.03 & 1.21 & 1.61 & 1.84 & 1.39 \\
2 & 1 & 1.26 & 1.59 & 1.68 & 1.70 & 1.76 & 1.88 \\
2 & 1 & 0.90 & 1.35 & 1.42 & 1.59 & 1.48 & 1.43 \\
2 & 1 & 0.85 & 1.14 & 1.17 & 1.26 & 1.35 & 1.45 \\
3 & 2 & 0.86 & 1.24 & 1.32 & 1.27 & 1.25 & 1.36 \\
3 & 1 & 0.72 & 0.77 & 0.48 & 0.68 & 1.06 & 1.22 \\
3 & 1 & 0.89 & 1.03 & 1.29 & 1.51 & 1.64 & 1.96 \\
3 & 2 & 0.72 & 0.94 & 1.03 & 1.21 & 1.25 & 1.25 \\
3 & 1 & 1.22 & 1.50 & 1.61 & 1.68 & 1.67 & 1.81 \\
3 & 1 & 0.52 & 0.74 & 0.88 & 0.98 & 1.04 & 1.12 \\
\hline
\end{tabular}

${ }^{2}$ LSI $=$ Lactation intake, $\mathrm{Trt}=$ group treatment, $\mathrm{Brd}=$ breed $(1=$ Holstein, $2=$ Ayrshire $)$ 
Appendix Table 17a. Data used to Calculate least square means for nonstructural carbohydrate intake in the dry period ${ }^{1}$

\begin{tabular}{lllll}
\hline Trt & Brd & NSC1 & NSC2 & NSC3 \\
\hline 1 & 2 & 3.16 & 3.23 & 2.58 \\
1 & 1 & 3.27 & 3.17 & 3.39 \\
1 & 1 & 4.22 & 4.04 & 3.63 \\
1 & 1 & 3.49 & 3.48 & 3.36 \\
1 & 1 & 3.52 & 3.34 & 3.39 \\
1 & 2 & 3.22 & 2.22 & 2.75 \\
2 & 1 & 3.21 & 3.25 & 2.73 \\
2 & 1 & 2.03 & 2.00 & 1.39 \\
2 & 1 & 2.58 & 3.46 & 2.27 \\
2 & 1 & 3.26 & 3.38 & 3.12 \\
2 & 1 & 3.57 & 3.30 & 2.60 \\
2 & 1 & 2.95 & 2.93 & 2.97 \\
3 & 2 & 2.22 & 2.30 & 2.26 \\
3 & 1 & 1.43 & 1.29 & 0.82 \\
3 & 1 & 2.49 & 3.14 & 2.05 \\
3 & 2 & 1.73 & 1.78 & 1.63 \\
3 & 1 & 2.50 & 2.66 & 2.69 \\
3 & 1 & 1.63 & 1.42 & 0.73 \\
\hline
\end{tabular}

${ }^{1} \mathrm{NSC}=$ dry period intake, $\mathrm{Trt}=$ group treatment $\mathrm{Brd}=$ breed $(1=$ Holstein, $2=$ Ayrshire $)$

Appendix Table 17b. Data used to calculate least square means for NSC intake during lactation ${ }^{2}$

\begin{tabular}{llllllll}
\hline Trt & Brd & LNS1 & LNS2 & LNS3 & LNS4 & LNS5 & LNS6 \\
\hline 1 & 2 & 3.62 & 4.37 & 4.64 & 5.37 & 5.62 & 5.76 \\
1 & 1 & 3.99 & 4.59 & 5.28 & 5.91 & 5.90 & 6.03 \\
1 & 1 & 5.16 & 7.13 & 7.42 & 7.65 & 7.98 & 7.78 \\
1 & 1 & 4.72 & 5.77 & 5.89 & 6.09 & 6.20 & 6.45 \\
1 & 1 & 4.86 & 6.39 & 6.58 & 7.12 & 7.81 & 8.02 \\
1 & 2 & 4.89 & 5.90 & 6.19 & 5.63 & 6.93 & 7.48 \\
2 & 1 & 4.60 & 5.08 & 5.56 & 6.23 & 6.53 & 6.74 \\
2 & 1 & 1.53 & 2.67 & 3.68 & 3.95 & 4.16 & 4.95 \\
2 & 1 & 1.72 & 4.48 & 5.34 & 6.83 & 7.84 & 6.77 \\
2 & 1 & 5.54 & 6.92 & 7.25 & 7.54 & 7.62 & 8.13 \\
2 & 1 & 3.86 & 5.90 & 6.17 & 6.90 & 6.42 & 6.24 \\
2 & 1 & 3.57 & 4.77 & 4.89 & 5.28 & 5.64 & 6.07 \\
3 & 2 & 4.03 & 5.77 & 6.08 & 6.00 & 5.86 & 6.19 \\
3 & 1 & 3.19 & 3.44 & 2.14 & 3.02 & 4.71 & 5.41 \\
3 & 1 & 4.15 & 4.74 & 5.74 & 6.89 & 7.48 & 8.86 \\
3 & 2 & 3.27 & 4.27 & 4.62 & 5.45 & 5.61 & 5.65 \\
3 & 1 & 5.24 & 6.45 & 6.79 & 7.11 & 7.13 & 7.77 \\
3 & 1 & 2.52 & 3.44 & 4.07 & 4.59 & 4.83 & 5.14 \\
\hline
\end{tabular}

${ }^{2} \mathrm{LNS}=$ lactation NSC intake, Trt = group treatment, Brd = breed $(1=$ Holstein, $2=$ Ayrshire $)$ 
Appendix Table 18a \& b. Data used to calculate least square means for organic matter intake $(\mathrm{kg})$ in the dry and lactation period $^{1}$

\begin{tabular}{ccccc}
\hline Trt & Brd & OMI1 & OMI2 & OMI3 \\
\hline 1 & 2 & 10.88 & 10.91 & 8.37 \\
1 & 1 & 11.19 & 10.53 & 10.76 \\
1 & 1 & 13.76 & 13.59 & 11.73 \\
1 & 1 & 11.32 & 11.17 & 10.54 \\
1 & 1 & 11.70 & 11.07 & 11.11 \\
1 & 2 & 10.71 & 7.13 & 8.76 \\
2 & 1 & 10.04 & 10.32 & 8.59 \\
2 & 1 & 6.71 & 6.45 & 4.26 \\
2 & 1 & 8.71 & 11.62 & 7.41 \\
2 & 1 & 9.25 & 10.86 & 8.47 \\
2 & 1 & 11.44 & 10.49 & 7.55 \\
2 & 1 & 8.96 & 8.81 & 8.63 \\
3 & 2 & 8.19 & 8.40 & 8.46 \\
3 & 1 & 5.32 & 5.29 & 3.88 \\
3 & 1 & 8.63 & 10.91 & 6.99 \\
3 & 2 & 6.33 & 6.48 & 5.97 \\
3 & 1 & 8.90 & 9.46 & 9.52 \\
3 & 1 & 6.16 & 5.53 & 3.36 \\
\hline
\end{tabular}

\begin{tabular}{cccccccc}
\hline Trt & Brd & LOM1 & LOM2 & LOM3 & LOM4 & LOM5 & LOM6 \\
\hline 1 & 2 & 9.75 & 12.15 & 12.67 & 14.78 & 15.78 & 16.03 \\
1 & 1 & 11.14 & 12.76 & 15.03 & 16.69 & 16.67 & 17.14 \\
1 & 1 & 14.40 & 20.03 & 20.73 & 21.55 & 22.51 & 21.95 \\
1 & 1 & 12.73 & 15.41 & 16.15 & 16.66 & 17.04 & 17.89 \\
1 & 1 & 13.40 & 17.23 & 18.63 & 20.05 & 22.12 & 22.58 \\
1 & 2 & 13.63 & 16.09 & 17.10 & 14.78 & 19.41 & 20.87 \\
2 & 1 & 11.48 & 13.24 & 14.61 & 16.26 & 17.42 & 17.97 \\
2 & 1 & 2.78 & 6.80 & 9.26 & 10.35 & 10.92 & 13.08 \\
2 & 1 & 2.56 & 11.67 & 13.74 & 18.35 & 20.89 & 15.79 \\
2 & 1 & 14.26 & 17.88 & 19.03 & 19.14 & 19.85 & 21.18 \\
2 & 1 & 10.11 & 15.15 & 15.98 & 17.88 & 16.70 & 16.06 \\
2 & 1 & 9.39 & 12.72 & 13.02 & 14.07 & 15.12 & 16.27 \\
3 & 2 & 9.87 & 14.10 & 15.06 & 14.46 & 14.30 & 15.52 \\
3 & 1 & 8.83 & 9.13 & 5.80 & 7.95 & 12.53 & 14.13 \\
3 & 1 & 10.28 & 11.80 & 14.73 & 17.28 & 18.83 & 22.48 \\
3 & 2 & 8.08 & 10.59 & 11.60 & 13.75 & 10.09 & 14.14 \\
3 & 1 & 13.99 & 17.17 & 18.42 & 19.15 & 19.12 & 20.74 \\
3 & 1 & 5.95 & 8.46 & 10.06 & 11.29 & 11.97 & 12.88 \\
\hline
\end{tabular}

${ }^{1} \mathrm{OMI}=$ dry period intake, $\mathrm{LOM}=$ lactation intake, $\mathrm{Trt}=$ treatment group, $\mathrm{Brd}=$ breed (1=Holstein, 2=Ayrshire) 
Appendix Table 19a. Data used to calculate least square means for fat intake during the dry period ${ }^{1}$.

\begin{tabular}{ccccc}
\hline Trt & Brd & DFI1 & DFI2 & DFI3 \\
\hline 1 & 2 & 0.20 & 0.21 & 0.16 \\
1 & 1 & 0.21 & 0.20 & 0.20 \\
1 & 1 & 0.26 & 0.25 & 0.22 \\
1 & 1 & 0.21 & 0.21 & 0.20 \\
1 & 1 & 0.22 & 0.21 & 0.21 \\
1 & 2 & 0.19 & 0.12 & 0.14 \\
2 & 1 & 0.23 & 0.23 & 0.19 \\
2 & 1 & 0.14 & 0.14 & 0.09 \\
2 & 1 & 0.18 & 0.25 & 0.17 \\
2 & 1 & 0.21 & 0.23 & 0.20 \\
2 & 1 & 0.23 & 0.22 & 0.16 \\
2 & 1 & 0.18 & 0.17 & 0.17 \\
3 & 2 & 0.17 & 0.17 & 0.17 \\
3 & 1 & 0.12 & 0.13 & 0.10 \\
3 & 1 & 0.18 & 0.23 & 0.15 \\
3 & 2 & 0.13 & 0.14 & 0.12 \\
3 & 1 & 0.18 & 0.19 & 0.19 \\
3 & 1 & 0.13 & 0.11 & 0.07 \\
\hline
\end{tabular}

${ }^{\mathrm{I}} \mathrm{DFI}=$ dry period inatke $(\mathrm{kg}), \mathrm{Trt}=$ treatment group

Brd $=$ breed $(1=$ Holstein, 2=Ayrshire $)$.

Appendix Table 19b. Data used to calculate least square means for fat intake during lactation ${ }^{2}$

\begin{tabular}{cccccccc}
\hline Trt & Brd & LFI1 & LFI2 & LFI3 & LFI4 & LFI5 & LFI6 \\
\hline 1 & 2 & 0.22 & 0.28 & 0.29 & 0.34 & 0.37 & 0.37 \\
1 & 1 & 0.25 & 0.29 & 0.35 & 0.38 & 0.38 & 0.40 \\
1 & 1 & 0.33 & 0.47 & 0.48 & 0.50 & 0.52 & 0.51 \\
1 & 1 & 0.29 & 0.35 & 0.37 & 0.38 & 0.39 & 0.41 \\
1 & 1 & 0.31 & 0.40 & 0.43 & 0.47 & 0.52 & 0.53 \\
1 & 2 & 0.32 & 0.38 & 0.40 & 0.35 & 0.46 & 0.49 \\
2 & 1 & 0.26 & 0.30 & 0.34 & 0.37 & 0.40 & 0.41 \\
2 & 1 & 0.03 & 0.15 & 0.19 & 0.23 & 0.24 & 0.29 \\
2 & 1 & 0.03 & 0.26 & 0.31 & 0.42 & 0.48 & 0.33 \\
2 & 1 & 0.32 & 0.41 & 0.43 & 0.43 & 0.45 & 0.48 \\
2 & 1 & 0.24 & 0.35 & 0.37 & 0.42 & 0.39 & 0.37 \\
2 & 1 & 0.22 & 0.30 & 0.30 & 0.33 & 0.35 & 0.38 \\
3 & 2 & 0.25 & 0.35 & 0.38 & 0.36 & 0.36 & 0.39 \\
3 & 1 & 0.22 & 0.25 & 0.17 & 0.21 & 0.34 & 0.37 \\
3 & 1 & 0.25 & 0.29 & 0.37 & 0.43 & 0.47 & 0.56 \\
3 & 2 & 0.20 & 0.27 & 0.29 & 0.35 & 0.35 & 0.35 \\
3 & 1 & 0.36 & 0.44 & 0.47 & 0.49 & 0.49 & 0.53 \\
3 & 1 & 0.15 & 0.22 & 0.26 & 0.29 & 0.30 & 0.33 \\
\hline
\end{tabular}

${ }^{2} \mathrm{LFI}=$ lactation fat intake, $\mathrm{Trt}=$ group treatment, $\mathrm{Brd}=$ breed $(1=$ Holstein, $2=$ Ayrshire $)$ 
Appendix table 20a. Data used to calculate least square means for starch intake in the dry period ${ }^{1}$.

\begin{tabular}{ccccc}
\hline Trt & Brd & STI1 & STI2 & STI3 \\
\hline 1 & 2 & 2.31 & 2.38 & 1.93 \\
1 & 1 & 2.40 & 2.36 & 2.56 \\
1 & 1 & 3.15 & 2.98 & 2.71 \\
1 & 1 & 2.59 & 2.59 & 2.52 \\
1 & 1 & 2.60 & 2.47 & 2.51 \\
1 & 2 & 2.36 & 1.64 & 2.03 \\
2 & 1 & 2.35 & 2.38 & 2.00 \\
2 & 1 & 1.50 & 1.48 & 1.04 \\
2 & 1 & 1.89 & 2.53 & 1.66 \\
2 & 1 & 2.44 & 2.49 & 2.35 \\
2 & 1 & 2.65 & 2.45 & 1.97 \\
2 & 1 & 2.23 & 2.22 & 2.27 \\
3 & 2 & 1.52 & 1.59 & 1.53 \\
3 & 1 & 1.00 & 0.87 & 0.51 \\
3 & 1 & 1.76 & 2.23 & 1.43 \\
3 & 2 & 1.16 & 1.20 & 1.08 \\
3 & 1 & 1.72 & 1.83 & 1.87 \\
3 & 1 & 1.06 & 0.88 & 0.32 \\
\hline
\end{tabular}

${ }^{\mathrm{T}} \mathrm{STI}=$ dry period intake $(\mathrm{Kg}), \mathrm{Trt}=$ group treatment $\mathrm{Brd}=$ breed $(1=$ Holstein, $2=$ Ayrshire $)$

Appendix Table 20b. Data used to calculate least square means for starch intake during lactation $^{2}$.

\begin{tabular}{cccccccc}
\hline Trt & Brd & LST1 & LST2 & LST3 & LST4 & LST5 & LST6 \\
\hline 1 & 2 & 2.79 & 3.33 & 3.56 & 4.11 & 4.26 & 4.39 \\
1 & 1 & 3.02 & 3.47 & 3.97 & 4.46 & 4.45 & 4.54 \\
1 & 1 & 3.91 & 5.39 & 5.62 & 5.78 & 6.02 & 5.87 \\
1 & 1 & 3.62 & 4.43 & 4.49 & 4.61 & 4.72 & 4.90 \\
1 & 1 & 3.69 & 4.89 & 4.96 & 5.38 & 5.89 & 6.06 \\
1 & 2 & 3.90 & 4.48 & 4.69 & 4.31 & 5.23 & 5.65 \\
2 & 1 & 3.59 & 3.92 & 4.28 & 4.80 & 5.00 & 5.16 \\
2 & 1 & 1.32 & 2.08 & 2.88 & 3.05 & 3.21 & 3.81 \\
2 & 1 & 1.50 & 3.45 & 4.13 & 5.22 & 6.00 & 5.38 \\
2 & 1 & 4.28 & 5.33 & 5.57 & 5.84 & 5.86 & 6.25 \\
2 & 1 & 2.96 & 4.55 & 4.75 & 5.31 & 4.94 & 4.81 \\
2 & 1 & 2.72 & 3.63 & 3.72 & 4.02 & 4.29 & 4.62 \\
3 & 2 & 3.17 & 4.53 & 4.76 & 4.73 & 4.61 & 4.83 \\
3 & 1 & 2.47 & 2.67 & 1.66 & 2.34 & 3.65 & 4.19 \\
3 & 1 & 3.26 & 3.71 & 4.45 & 5.38 & 5.84 & 6.90 \\
3 & 2 & 2.55 & 3.33 & 3.59 & 4.24 & 4.36 & 4.40 \\
3 & 1 & 4.02 & 4.95 & 5.18 & 5.43 & 5.46 & 5.96 \\
3 & 1 & 2.00 & 2.70 & 3.19 & 3.61 & 3.79 & 4.02 \\
\hline
\end{tabular}

${ }^{2} \mathrm{LST}=$ lactation intake, $\mathrm{Trt}=$ group treatment, $\mathrm{Brd}=$ breed $(1=$ Holstein, $2=$ Ayrshire $)$ 
Appendix Table 21. Data used to calculate least square means for NDF intake as percent of body weight ${ }^{1}$.

\begin{tabular}{cccccccc}
\hline Trt & Brd & BNDF1 & BNDF2 & BNDF3 & BNDF4 & BNDF5 & BNDF6 \\
\hline 1 & 2 & 0.80 & 0.64 & 0.60 & 0.78 & 0.94 & 1.02 \\
1 & 1 & 0.78 & 0.77 & 0.64 & 0.79 & 1.01 & 1.02 \\
1 & 1 & 1.13 & 0.95 & 0.89 & 1.28 & 1.39 & 1.37 \\
1 & 1 & 0.80 & 0.76 & 0.74 & 0.95 & 1.01 & 1.14 \\
1 & 1 & 0.77 & 0.73 & 0.70 & 0.99 & 1.18 & 1.24 \\
1 & 2 & 0.76 & 0.59 & 0.75 & 0.92 & 0.97 & 1.21 \\
2 & 1 & 0.73 & 0.68 & 0.82 & 0.96 & 1.21 & 1.22 \\
2 & 1 & 0.57 & 0.41 & 0.15 & 0.59 & 0.81 & 1.02 \\
2 & 1 & 0.57 & 0.61 & 0.05 & 0.67 & 1.07 & 0.77 \\
2 & 1 & 0.56 & 0.55 & 0.85 & 1.11 & 1.18 & 1.24 \\
2 & 1 & 1.01 & 0.66 & 0.74 & 1.05 & 1.19 & 1.07 \\
2 & 1 & 0.72 & 0.67 & 0.59 & 0.86 & 0.99 & 1.10 \\
3 & 2 & 0.74 & 0.80 & 0.59 & 0.87 & 0.88 & 1.02 \\
3 & 1 & 0.49 & 0.49 & 0.64 & 1.20 & 0.86 & 1.14 \\
3 & 1 & 0.56 & 0.45 & 0.60 & 0.77 & 1.02 & 1.27 \\
3 & 2 & 0.55 & 0.57 & 0.50 & 0.70 & 0.91 & 0.94 \\
3 & 1 & 0.64 & 0.67 & 0.72 & 0.97 & 1.03 & 1.06 \\
3 & 1 & 0.62 & 0.43 & 0.46 & 0.73 & 0.91 & 1.00 \\
\hline
\end{tabular}

${ }^{1}$ BNDF1 = 3 weeks prepartum, BNDF2 = calving, BNDF3 = wk 1 postcalving, BNDF4 = 2 wks postcalving

BNDF5 $=4 \mathrm{wks}$ postcalving, BNDF6 $=6 \mathrm{wks}$ postcalving. 
Appendix Table 22. Data used to calculate least square means for Body weight $(\mathrm{Kg})^{1}$.

\begin{tabular}{ccccccc}
\hline Trt & Brd & BW1 & BW2 & BW3 & BW4 & BW5 \\
\hline 1 & 2 & 659 & 608 & 597 & 611 & 591 \\
1 & 1 & 686 & 627 & 639 & 605 & 623 \\
1 & 1 & 589 & 595 & 586 & 591 & 595 \\
1 & 1 & 643 & 607 & 589 & 602 & 573 \\
1 & 1 & 709 & 700 & 659 & 667 & 676 \\
1 & 2 & 657 & 673 & 655 & 634 & 639 \\
2 & 1 & 624 & 578 & 561 & 534 & 559 \\
2 & 1 & 572 & 485 & 482 & 470 & 466 \\
2 & 1 & 755 & 615 & 667 & 661 & 650 \\
2 & 1 & 665 & 582 & 584 & 571 & 598 \\
2 & 1 & 530 & 485 & 517 & 511 & 526 \\
2 & 1 & 559 & 559 & 535 & 527 & 534 \\
3 & 2 & 571 & 558 & 566 & 545 & 531 \\
3 & 1 & 565 & 492 & 487 & 454 & 459 \\
3 & 1 & 682 & 594 & 607 & 623 & 627 \\
3 & 2 & 592 & 545 & 545 & 533 & 516 \\
3 & 1 & 700 & 716 & 684 & 692 & 723 \\
3 & 1 & 515 & 446 & 445 & 450 & 454 \\
\hline
\end{tabular}

${ }^{\mathrm{I}} \mathrm{BW} 1=3$ weeks prepartum, $\mathrm{BW} 2=$ calving, $\mathrm{BW} 3=2 \mathrm{wks}$ postpartum, $\mathrm{BW} 4=4 \mathrm{wks}$ postpartum, $\mathrm{BW} 5=6$ weeks postpartum.

\begin{tabular}{ccccccc}
\multicolumn{6}{c}{ Appendix Table 23. Data used to calculate least square means for body co } \\
\hline Trt & Brd & BCS1 & BCS2 & BCS3 & BCS4 & BCS5 \\
\hline 1 & 2 & 4 & 3.5 & 3.5 & 3.25 & 3.0 \\
1 & 1 & 3.5 & 3.25 & 3.0 & 3.0 & 3.0 \\
1 & 1 & 3.0 & 3.25 & 3.0 & 3.25 & 3.25 \\
1 & 1 & 3.5 & 3.5 & 3.0 & 3.25 & 3.0 \\
1 & 1 & 3.75 & 3.5 & 3.25 & 3.25 & 3.25 \\
1 & 2 & 4.25 & 3.75 & 3.75 & 3.75 & 3.75 \\
2 & 1 & 3.25 & 2.5 & 2.5 & 2.5 & 2.5 \\
2 & 1 & 3.75 & 3.25 & 3.25 & 3.25 & 3.25 \\
2 & 1 & 3.0 & 2.5 & 2.75 & 2.5 & 2.5 \\
2 & 1 & 3.5 & 3.0 & 2.75 & 2.75 & 2.75 \\
2 & 1 & 2.5 & 2.5 & 2.75 & 2.75 & 2.75 \\
2 & 1 & 3.25 & 3.25 & 3.0 & 3.0 & 3.75 \\
3 & 2 & 4.0 & 3.25 & 3.0 & 3.0 & 3.0 \\
3 & 1 & 3.75 & 3.5 & 3.25 & 3.0 & 3.0 \\
3 & 1 & 3.25 & 3.0 & 3.0 & 2.75 & 2.75 \\
3 & 2 & 4.0 & 3.5 & 3.5 & 3.25 & 3.0 \\
3 & 1 & 3.0 & 3.25 & 3.0 & 3.0 & 3.25 \\
3 & 1 & 3.5 & 2.75 & 2.75 & 2.75 & 2.75 \\
\hline
\end{tabular}

${ }^{\mathrm{T}} \mathrm{BCS} 1=3$ wks prepartum, $\mathrm{BCS} 2=$ calving, $\mathrm{BCS} 3=2 \mathrm{wks}$ postpartum $\mathrm{BCS} 4=4 \mathrm{wks}$ postpartum, $\mathrm{BCS} 5=6 \mathrm{wks}$ postpartum. 


\section{VITA}

Name: $\quad$ Wellington Sifuna Mang'oli

Birth place: $\quad$ Kakamega District, Western Province- Kenya

Date of birth: $\quad$ September 17, 1959

Parents: $\quad$ Mang'oli Barnabas Namayi

Nakhumwa Sillah Mang'oli

Wife: $\quad$ Khasandi Judith Sifuna

Sons: $\quad$ Andrew Sifuna

Philip Sifuna

Institutes attended: Chebuyusi Pr. School Kakamega - Kenya 1966 - 1973

Chebuyusi Secondary School Kakamega - Kenya 1974 - 1977

Friends' School Kamusinga Bungoma - Kenya 1978 - 1979

Egerton University $\quad$ Njoro - Kenya $1980-1983$

West Virginia University Morgantown- WV 1992 - 1994

West Virginia University Morgantown - WV 1997 - to date

Degrees Awarded: $\quad$ Diploma in Animal Husbandry 1983

Egerton University

Bachelor of Sc. Agric. (Animal \& Vet. Sciences) 1994

West Virginia University

Employment: Min. of Agriculture and Livestock Dev.

Kenya

Title/Duration: $\quad$ Livestock Extension Officer

1983 - to date 


\section{APPROVAL OF EXAMINING COMMITTEE}

John Killefer, Ph. D.

Edward C. Prigge, Ph. D.

William H. Hoover, Ph. D.

Chairman

1999

Date 